
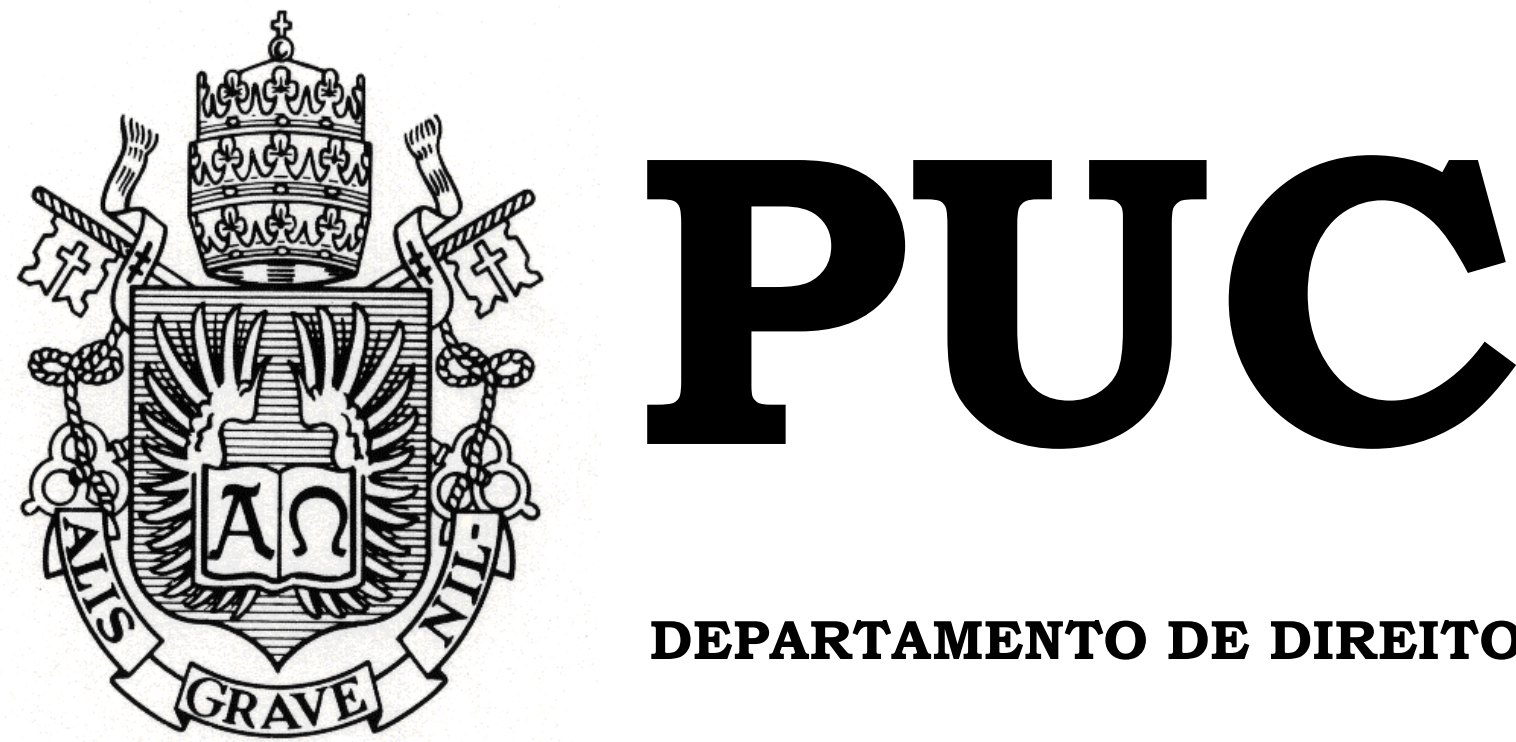

DEPARTAMENTO DE DIREITO

\title{
A EFETIVIDADE DOS DIREITOS SOCIAIS: UM ESTUDO SOBRE DIREITO À EDUCAÇÃO NO CONTEXTO DA POPULAÇÃO SURDA
}

BARBARA EVELIN DA CONCEIÇÃO RAMOS

ORIENTADOR: THIAGO RAGONHA VARELA

\section{1}

PONTIFÍCIA UNIVERSIDADE CATÓLICA DO RIO DE JANEIRO

RUA MARQUÊS DE SÃO VICENTE, 225 - CEP 22453-900

RIO DE JANEIRO - BRASIL 


\title{
A EFETIVIDADE DOS DIREITOS SOCIAIS: UM ESTUDO SOBRE O DIREITO À EDUCAÇÃO NO CONTEXTO DA POPULAÇÃO SURDA
}

\author{
por
}

\section{BARBARA EVELIN DA CONCEIÇÃO RAMOS}

\author{
Monografia apresentada ao \\ Departamento de Direito da Pontifícia \\ Universidade Católica do Rio de \\ Janeiro (PUC-Rio) como requisito \\ parcial para a obtenção do título de \\ Bacharel em Direito.
}

Orientador(a): THIAGO RAGONHA VARELA

2016.1 
"Respondeu-lhe o Senhor: Quem fez a boca do homem? Ou quem faz o mudo, ou o surdo, ou o que vê, ou o cego? Não sou eu, o SENHOR?

$[\ldots]$

Não amaldiçoarás o surdo, nem porás tropeço

diante do cego; mas temerás o teu Deus. Eu sou o SENHOR."

(Êxodo 4:11; Levítico 19:14) 


\section{Agradecimentos}

À Deus, primeiramente, porque antes mesmo que eu $\mathrm{O}$ conhecesse me amou incondicionalmente, me deu sentido me mostrando que a vida pode ser muito mais atraente quando deixamos de simplesmente existir para viver experiências com Ele.

À minha mãe, Márcia Barbara, que fez tudo quanto estava a seu alcance para me proporcionar o melhor que esta vida poderia me oferecer.

À minha irmã, Pamela Winnie, minha amiga, meu escape quando a rotina queria me tragar, a completude da minha risada.

Ao Paulo, que muito bem assumiu o papel de pai, sendo também grande incentivador da busca dos meus objetivos.

Ao professor Thiago Varela, que prontamente abraçou a ideia deste trabalho, por todo suporte, correções e disponibilidade.

Aos mães, pais e responsáveis que contribuíram para esta pesquisa compartilhando de suas experiências e angústias.

À Professora Maria Fernanda, que mesmo à distância me deu grande suporte na realização deste trabalho.

À professora Telma Lage, que despertou-me à necessidade de dar efetividade aos direitos sociais durante o PIBIC.

Aos meus primeiros professores de Libras, Natállia Maia e Isaac Gomes, que me apresentaram a cultura surda, por todo auxílio neste trabalho.

À minha primeira professora surda, Alexandra Paiva, por toda dedicação e paciência nas aulas de Libras e todo material que me disponibilizou.

Aos defensores públicos Judith Regis e Bernardo Dias, por me mostrarem na prática que ainda vale a pena crer na Justiça Brasileira.

Às minhas colegas de curso, hoje formadas, Cilaine Lourenço e Rebeca Peterli, por todo incentivo, conversas e materiais compartilhados.

Às amigas de curso Fernanda Calçada e Luciana Lima, por todas as risadas, aniversários comemorados e pela presença do início ao fim do curso. 
À amiga de curso Andréa Costa, por todas as conversas produtivas, apoio, companheirismo e por ser uma pessoa exemplar.

À amiga de curso Luiza Ramos, pelo acompanhamento em audiências e trabalhos, e todas as ótimas conversas.

À minha amiga Ester Levi, por sempre surgir com ótimas ideias de passeios para aliviar a tensão da rotina.

Ao Pablo Martins, por todo apoio, motivação, orações e compreensão, essenciais para ter tranquilidade para produção deste trabalho.

À Érica Reis, minha (sempre) discipuladora, por me ajudar a vencer os desafios da vida acadêmica e no meu crescimento espiritual.

Aos amigos das reuniões de Quebra Gelo do Movimento Estudantil Alfa e Ômega, pela edificação mútua, amizade e divertimento.

À Cruzada Estudantil e Profissional para Cristo, pelo amor a este povo não alcançado, futuros líderes da nação, os universitários.

Aos meus professores do ensino médio no Colégio Pedro II - UESC III, pelo estímulo e por acreditarem no potencial de seus alunos.

Aos funcionários do departamento de direito e demais funcionários da PUC-Rio, pela disposição, atenção e simpatia.

Aos professores deste departamento, principalmente os de Constitucional, que foram essenciais a minha formação com ênfase em Estado e Sociedade. $\mathrm{E}$ a todos os demais não mencionados que contribuíram direta ou indiretamente para minha formação, meus sinceros agradecimentos.

Deus os abençoe! 


\section{Resumo}

O presente trabalho tem o objetivo de analisar as violações ao direito à educação da população surda no município do Rio de Janeiro, demonstrando a negligência e desinteresse do Poder Público em promover um real e efetivo acesso a tal direito. À vista disso, explora os seguintes aspectos: (i) o caráter fundamental dos direitos sociais, especialmente o direito social à educação para a formação do indivíduo em perspectiva; (ii) os principais problemas do modelo de escola básica, no ensino público, atual na educação de surdos; (iii) a experiência de escolas da rede pública e privada com alunos surdos e pais, mães e responsáveis por estudantes surdos; (iv) os principais meios de reivindicação judicial deste direito como direito fundamental; (v) o modelo ideal de educação básica para pessoas surdas, tendo em vista a ineficiência dos moldes atuais diante da realidade apresentada pelo estudo do tema, a experiência das escolas e responsáveis e a letra da Carta Magna e leis infra-constitucionais, propondo uma reforma educacional para uma verdadeira acessibilidade.

\section{Palavras-chave}

direito, pessoa surda, educação básica, rede pública, efetividade. 
Sumário

INTRODUÇÃO ............................................................................................................ 10

1. DOS DIREITOS FUNDAMENTAIS SOCIAIS .................................13

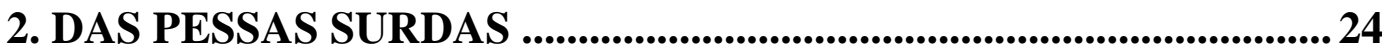

2.1. Modelos Educacionais para Surdos...................................................... 32

2.2. Instituições Importantes na Educação de Surdos no Rio de

Janeiro...................................................................................................................36

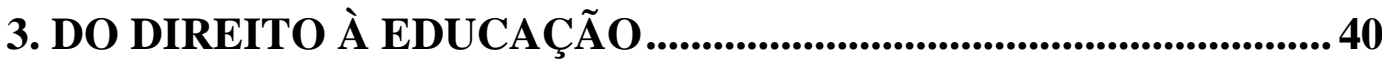

3.1. Legislação sobre a Educação de Pessoas Surdas............................. 46

3.1.1. De Âmbito Federal ............................................................................... 46

3.1.2. De Âmbito Estadual ....................................................................56

3.1.3. De Âmbito Municipal....................................................................59

4. DA TUTELA JURISDICIONAL: MECANISMOS PROCESSUAIS

DE ACESSO AO DIREITO À EDUCAÇÃO ..........................................66

4.1. Ação Direta de Inconstitucionalidade por Omissão - ADI por

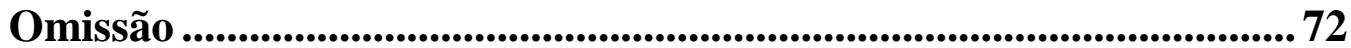

4.2. Mandado de Injunção - MI ................................................................. 75

4.3. Mandado de Segurança - MS .............................................................. 78

4.4. Mandado de Segurança Coletivo - MS Coletivo............................ 79

4.5. Arguição de Descumprimento de Preceito Fundamental - ADPF 
6. A IMPORTÂNCIA DA ESCOLA BILÍNGUE NA EFETIVIDADE DO DIREITO À EDUCAÇÃO DA PESSOA SURDA...............................99

7. CONSIDERAÇÕES FINAIS.................................................................. 110

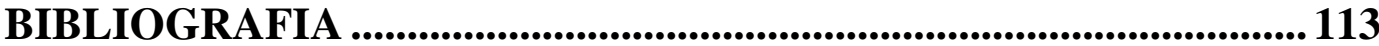




\section{Lista De Abreviações}

ABBR - Associação Brasileira Beneficente de Reabilitação

ADCT - Ato das Disposições Constitucionais Transitórias

ADI - Ação Direta de Inconstitucionalidade

ADPF - Arguição de Descumprimento de Preceito Fundamental

AEE - Atendimento Educacional Especializado

ASL - American Sign Language

CASSI - Caixa de Assistência dos Funcionários do Banco do Brasil

CRE - Coordenadoria Regional de Educação

CRFB - Constituição da República Federativa do Brasil de 1988

DF - Distrito Federal

IBGE - Instituto Brasileiro de Geografia e Estatística

INOSEL - Instituto Nossa Senhora de Lourdes

LDB - Lei de Diretrizes e Bases da Educação

Libras - Língua Brasileira de Sinais

LSF - Langue des Signes Française

MEC - Ministério da Educação e Cultura

MI - Mandado de Injunção

MS - Mandado de Segurança

OMS - Organização Mundial da Saúde

ONU - Organização das Nações Unidas

PIDESC - Pacto Internacional de Direitos Econômicos, Socais e Culturais

SECADI - Secretaria de Educação Continuada, Alfabetização, Diversidade

e Inclusão

SME - Secretaria Municipal de Educação

STF - Supremo Tribunal Federal

STJ - Superior Tribunal de Justiça

SUS - Sistema Único de Saúde

TJ - Tribunal de Justiça 
UNESCO - Organização das Nações Unidas para a Educação, a Ciência e a Cultura 


\section{INTRODUÇÃO}

O presente estudo tem por objeto a análise das violações ao direito à educação da população surda no Rio de Janeiro e a responsabilidade e omissão do Poder Público em promover a efetividade deste direito através de políticas públicas capazes de assegurar verdadeiro acesso à educação. A partir da análise de dados concretos é sugerido um olhar ao direito à educação como condição necessária ao desenvolvimento da potencialidade do indivíduo e não como atrelado simplesmente a ampliação do acesso ao ambiente escolar.

A Constituição da República Federativa do Brasil vigente, considerada a mais democrática Constituição Brasileira até então, traz direitos e garantias fundamentais e princípios que devem servir de base de interpretação destes direitos, tudo isto para que se alcance de fato um Estado Democrático de Direito. Garantindo a igualdade, a liberdade e a dignidade humana, para que cada indivíduo possa se desenvolver plenamente, para o progresso da nação.

No entanto, a realidade da vida prática faz parecer que a letra da Lei Fundamental seja mera letra. O que é inadmissível. Ocorre que para que a educação seja plena esta deve corresponder às necessidades do indivíduo em desenvolvimento, o que quer dizer que o mesmo método de ensino não é efetivo a todos os alunos, pois condições sensoriais como a surdez exigem tratamento diferenciado para a verdadeira compreensão do que se ensina e cabe ao Poder Público, no seu dever de prestar educação básica de qualidade, fornecer as condições necessárias ao seu aprendizado.

A realidade das escolas do Rio de Janeiro são de salas de aula com alunos surdos e ouvintes, no qual o professor aplica o método costumeiro de ensino, enquanto os alunos surdos são tratados também como ouvintes, os professores não têm conhecimento de Libras ou o conhecimento é precário, além de que se estimula a leitura labial ou oralização sem que haja um 
ensinamento efetivo do português, ou estes alunos são deixados de lado, e o tempo que passam na escola não serve para nenhum aprendizado. Além de que a cultura surda não é estimulada, muitas vezes desconhecida pelos profissionais da educação.

Vale ressaltar que isto não se deve a negligência das escolas ou despreparo dos profissionais da educação, mas ao Poder Executivo que não dá a estes o aparato necessário para trabalhar com estes alunos, e desta forma, têm de se desdobrar com todas as limitações de materiais e de profissionais. $\mathrm{O}$ que ficou claro mediante pesquisa de campo realizada em diversas escolas da rede pública e privada e com mães, pais e responsáveis por alunos surdos.

Portanto, resta demonstrada a inobservância do caput do artigo 205 da Constituição da República Federativa do Brasil que diz que a educação deve favorecer o "pleno desenvolvimento da pessoa, seu preparo para o exercício da cidadania e sua qualificação para o trabalho", porquanto o modelo atual da educação pública não é capaz de fornecer à pessoa surda os recursos educacionais necessários.

Neste sentido, o presente trabalho requer evidenciar como tal omissão do Poder Público representa o descumprimento do disposto constitucional e, assim, sendo passível de ação judicial que reconheça e imponha ao agente omisso do Poder Executivo atos que contribuam para a eficácia da Constituição Brasileira.

$\mathrm{E}$, diante desta necessidade, propõe-se a postulação do direito à educação por via judicial, uma vez que representa um direito fundamental social e a Carta Magna assegura o pleito em juízo de tais direitos, inclusive pela declaração de inconstitucionalidade por omissão. Por conseguinte, serão apresentados os meios judiciais cabíveis.

Ademais, apresenta um modelo de educação para pessoas surdas que pretende maior eficácia no ensino e compreensão culminando no pleno desenvolvimento do aluno e, por conseguinte, seu preparo para o exercício da cidadania e capacitação para o trabalho. O modelo de escola bilíngue, 
que compreende a Libras como língua brasileira e meio legal de comunicação, oriunda da comunidade surda, e, desta forma, principal meio de comunicação das pessoas surdas, no entanto, sem descartar a língua portuguesa, mas exigindo-se esta apenas na modalidade escrita, o que atende à Lei de Libras (Lei $n^{\circ}$. 10.436, de 2002) e garante também o respeito a esta minoria linguística. 


\section{DOS DIREITOS FUNDAMENTAIS SOCIAIS}

"Respeitar o Surdo como cidadão é, antes de mais nada,
querer que esse cidadão faça parte da nação."

(Catarina Kiguti)

Para se discorrer a cerca dos Direitos Sociais é necessário iniciar tratando dos Direitos Fundamentais, compreendendo que aqueles são originados por estes e os direitos fundamentais decorrem dos direitos humanos, portanto, iniciaremos este capítulo abordando aspectos de Direitos Humanos, pois se entende que estes dão origem a noção de Direitos Fundamentais, que representariam a positivação daqueles.

Direitos Humanos derivam da ideia de que todos os seres humanos são iguais em direitos, não sendo tolerado qualquer tipo de discriminação negativa $^{1}$ em virtude de raça, cor, sexo, condições socioeconômicas, ou qualquer outro motivo. Todos devem ter igualdade de condições de acesso aos seus direitos, tais como, direitos políticos, de liberdade, de igualdade, sem distinções de natureza política, jurídica ou qualquer outra, visando a garantia da dignidade humana.

Alexandre de Moraes define da seguinte forma:

"O conjunto institucionalizado de direitos e garantias do ser humano que tem por finalidade básica o respeito a sua dignidade, por meio de sua proteção contra o arbítrio do poder estatal e o estabelecimento de condições mínimas de vida e desenvolvimento da personalidade humana pode ser definido como direitos humanos fundamentais." (Moraes, 2000, p.39)

Os Direitos Humanos surgiram da conjugação de doutrinas filosóficas e jurídicas, das ideias advindas do cristianismo e do direito natural. O direito natural, compreende que há um conjunto de princípios que provêm do fato de ser pessoa humana apenas, princípios estes relativos a personalidade que pretendem seu bem-estar e desenvolvimento, logo,

\footnotetext{
${ }^{1}$ Tema a ser tratado mais adiante, pode-se conceituar discriminação negativa àquela que de encontro ao art. $5^{\circ}, \mathrm{XLI}$, da CRFB, diferenciações arbitrárias e que desestimulam a inclusão de grupos vulneráveis socialmente.
} 
antecedem a existência da pessoa humana, tais como direito à vida, à honra etc. E o cristianismo com a mensagem de igualdade de todos os homens, todos criação de Deus, trazendo princípios de justiça e igualdade conforme resgata Afonso Arinos de Melo Franco:

\begin{abstract}
"Finalmente, queremos deixar consignada a nossa convicção de que não se pode separar o reconhecimento dos direitos individuais da verdadeira democracia. Com efeito, a ideia democrática não pode ser desvinculada das suas origens cristãs e dos princípios que o Cristianismo legou à cultura política humana: o valor transcendente da criatura, a limitação do poder pelo Direito e a limitação do Direito pela justiça. Sem respeito à pessoa humana não há justiça. E sem justiça não há Direito." (1958, p.188)

O ponto central de interseção destas doutrinas estava na carência de limitação do poder do Estado, controlando os abusos de suas autoridades, e a consagração de princípios essenciais de igualdade e legalidade sob os quais deveriam se fundar todos os atos de Poder, e não só estes, mas toda a
\end{abstract} estrutura estatal.

Desta forma, esta categoria de direitos quando positivada se põe acima de todos os demais direitos, servindo de base de interpretação e criação destes. Sendo assim, os direitos humanos apresentam, segundo Alexandre de Moraes (2000, p.41) características peculiares, como:

a) imprescritibilidade: uma vez que o decurso do tempo não afasta tais direitos;

b) inalienabilidade: visto que não se pode transferi-los de nenhuma maneira, seja onerosa ou gratuita;

c) irrenunciabilidade: pois, o titular destes direitos não pode abandoná-los, não são passíveis de renúncia;

d) inviolabilidade: porque não podem ser violados por ninguém, nem mesmo autoridade pública ou ordenamento jurídico;

e) universalidade: abarca todos os indivíduos, independente de raça, credo, sexo, etc;

f) efetividade: dado que o simples reconhecimento destes direitos requer atuação do Poder Público no sentido de garantir a efetivação dos direitos e garantias previstos, se utilizando dos 
mecanismos coercitivos necessários, posto que a Constituição Federal não se satisfaz apenas com o reconhecimento abstrato; g) interdependência: já que, embora as disposições constitucionais sejam independentes para existir, para o alcance de suas finalidades interceptam-se, como é o caso do uso de remédios constitucionais, por exemplo, habeas corpus, habeas data, mandado de segurança;

h) complementariedade: porquanto tais direitos carecem de interpretação de forma conjunta visando atingir o intento do constituinte.

Devido a isto a Declaração dos Direitos do Homem e do Cidadão de 1781 foi de grande relevância ao ser o instrumento a assentir a existência de direitos considerados naturais e inalienáveis do indivíduo, a de maior cunho individualista até então e combate a regalias exclusivas de determinadas categorias, embora o termo "direitos humanos" só tenha sido incorporado a partir da Declaração Universal dos Direitos Humanos em 1948, a ideia era a mesma: o reconhecimento da necessidade de documento de ordem jurídica positiva que assegurasse a todas as pessoas o exercício de direitos mínimos a dignidade humana.

Esta é a importância da positivação no ordenamento interno, assegurar consequência jurídica de âmbito interno a fim de promover direitos de proteção a dignidade da pessoa humana, a dignidade da pessoa que estará sob aquela jurisdição. Assim, os direitos fundamentais representam a limitação do poder estatal interno e reconhecimento de direitos básicos a todo indivíduo abarcado por aquele ordenamento.

Vale ressaltar a distinção dada por J.J. Gomes Canotilho sobre os direitos do homem/direitos humanos e direitos fundamentais:

\footnotetext{
“As expressões «direitos do homem» e «direitos fundamentais» são frequentemente utilizados como sinónimas. Segundo a sua origem e significado poderíamos distingui-las da seguinte maneira: direitos do homem são direitos válidos para todos os povos e em todos os tempos (dimensão jusnaturalistauniversalista); direitos fundamentais são os direitos do homem, jurídico-
} 
institucionalmente garantidos e limitados espacio-temporalmente." (Canotilho, 2003, p.393)

Direitos Humanos incorporados no ordenamento interno são tratados por direitos fundamentais. Sendo a Constituição Federal o escopo para toda a estrutura estatal a melhor maneira de se receber estes direitos no ordenamento jurídico interno seria por meio da constitucionalização destes. Somente desta maneira se pode construir um Estado Democrático de Direitos.

Sobre o papel da Constituição diz José Afonso da Silva:

\begin{abstract}
"A constituição do Estado, considerada sua lei fundamental, seria, então, a organização dos seus elementos essenciais: um sistema de normas jurídicas, escritas ou costumeiras, que regula a forma do Estado, a forma de seu governo, o modo de aquisição e o exercício do poder, o estabelecimento de seus órgãos, os limites de sua ação, os direitos fundamentais do homem $e$ as respectivas garantias. Em síntese, a constituição é o conjunto de normas que organiza os elementos constitutivos do Estado." (2014, p.39,40)
\end{abstract}

Portanto quando na Constituição da República Federativa do Brasil em 1988 foi posto no artigo $1^{\circ}$, inciso III $^{3}$ que a dignidade da pessoa humana seria fundamento deste Estado, quer dizer que foi assumido um compromisso de garantir meios de efetivação de direitos que garantam a dignidade humana em seu sentido mais amplo, a fim de se produzir um Estado Democrático de Direito. E isto disposto na Constituição não produz efeitos apenas declaratórios, este não é o papel do Direito, muito menos do Direito Constitucional. É o entendimento de Walter Guandalin Jr. (2012, p.40) que o Direito não traz apenas preceitos de atuações, mas verdadeiros roteiros, planos que indicam aos atores seus modos de agir, deixando margem para improvisações, porém sem retirar o caráter preconizador da norma, mas atribuir a esta método mais adequado a sua compreensão,

\footnotetext{
${ }^{2}$ Para uma visão tridimensional dos direitos fundamentais - dimensão jusnaturalista, dimensão universalista e dimensão constitucional - cfr. VIEIRA DE ANDRADE, Os direitos fundamentais, Coimbra, 1983, pp. 3 e ss. Apud: CANOTILHO, J.J. Gomes. Direito Constitucional; e teoria da Constituição. $7^{\text {a }}$ ed. Coimbra: Livraria Almedina, 2003.

3 “Art. $1^{\circ}$ A República Federativa do Brasil, formada pela união indissolúvel dos Estados e Municípios e do Distrito Federal, constitui-se em Estado Democrático de Direito e tem como fundamentos: I - a soberania; II - a cidadania; III - a dignidade da pessoa humana; IV - os valores sociais do trabalho e da livre iniciativa; V - o pluralismo político.

Parágrafo único. Todo o poder emana do povo, que o exerce por meio de representantes eleitos ou diretamente, nos termos desta Constituição.” (Brasil, Constituição Federal de 1988).
} 
norteando a ação, criando possibilidades e narrando novos fatos, novas práticas.

Afirma ainda o autor supramencionado:

“A adoção desse método pelo saber jurídico permitirá compreender um aspecto do Direito que tem sido reiteradamente negligenciado pelas análises formalistas e economicistas: a sua realidade como narrativa literária, o que significa que ele atua simultaneamente como síntese simbólica estabilizadora das aspirações sociais do presente e projeto de (imagin-)ação transformador para a sociedade do futuro.” (Guandalin JR., 2012, p.40)

Apenas com a conexão do texto constitucional à realidade fática e contexto social, cultural, econômico e histórico, da sociedade para que a norma faça sentido e seja dotada de ampla eficácia, encontrando berço aos seus ideais para que evoluam à transformação social.

Ainda mais tratando de direitos fundamentais, a compreensão da norma é fundamental à efetivação do que nela se dispõe. Conforme afirma J. J. Gomes Canotilho (2003, p.378, 379), os direitos fundamentais devem ser os pilares estruturadores da República, baseando-a na dignidade da pessoa humana, enquanto o Estado Democrático de Direito tem suas bases "no respeito e na garantia de efetivação dos direitos e liberdades fundamentais", tornando assim estas normas, na qualidade de constitucionais, parâmetro de controle de constitucionalidade e dotando de obrigatoriedade a sua aplicação.

Ter os Direitos Fundamentais dispostos na Constituição Federal Brasileira reflete a vontade da soberania popular em ter garantidos direitos essenciais a uma vida digna. Diz ainda J. J. Gomes Canotilho que devem ser interpretados como "normas jurídicas vinculativas" (2003, p.378). Portanto, a constitucionalização dos direitos fundamentais não serve apenas como princípios norteadores da interpretação dos demais dispositivos ou mera formalidade, mas significa também ter assegurada a concretização de direitos, empoderando o indivíduo para pleitear amparo em juízo para tornar efetivo este Estado Democrático de Direito. Desse modo é absolutamente indispensável a intervenção do Poder Judiciário para a aplicabilidade e cumprimento dos direitos fundamentais. 
É a partir do Título II da nossa Constituição Federal atual que começa a tratar "direitos e garantias fundamentais". Iniciando pelo artigo $5^{\circ}$, cuja disposição diz:

"Art. $5^{\circ}$ Todos são iguais perante a lei, sem distinção de qualquer natureza, garantindo-se aos brasileiros e aos estrangeiros residentes no País a inviolabilidade do direito à vida, à liberdade, à igualdade, à segurança e à propriedade, nos termos seguintes:" (Brasil, 1988)

Fato é que ao falarmos de igualdade não estamos falando apenas da igualdade formal, aquela que diz do tratamento igual perante a lei vedando qualquer tipo de tratamento diferenciado aos iguais (Silva, S.P.M., 2005, p.32), sem levar em consideração a pessoa em si, pois a preocupação apenas com a igualdade formal corre o risco de fomentar as desigualdades produzindo um Estado insensível às questões de ordem social.

Faz-se necessário também a igualdade material, aquela que impõe ao Estado uma atuação intervencionista, a prestação de serviços, a fim de criar condições materiais de forma a proporcionar as necessidades consideradas vitais do indivíduo para que tenha uma vida digna, como assinala Renata Malta Vilas-Bôas ${ }^{4}$, quando a Constituição Federal fala de igualdade está dando destaque "para o princípio da igualdade material, o qual decorre da necessidade de tratamento prioritário e diferenciado àqueles grupos ou pessoas que são carecedores da igualdade, em razão de circunstâncias específicas” (Silva, S.P.M., 2005, p.41).

E em diversas outras disposições a Carta Magna afirma isto, por exemplo, aduz o artigo 206, inciso I que “O ensino será ministrado com base nos seguintes princípios: I - igualdade de condições para o acesso e permanência na escola;".

Deste modo, compreende-se que a igualdade material se manifesta por meio da discriminação positiva, definida por Sidney Pessoa Madruga da Silva da seguinte forma:

\footnotetext{
${ }^{4}$ VILAS-BÔAS, Renata Malta. Ações afirmativas e o princípio da igualdade. Rio de Janeiro: América Jurídica, 2003. Apud: SILVA, Sidney Pessoa Madruga da. Discriminação positiva: ações afirmativas da realidade brasileira. Brasília: Brasília Jurídica, 2005.
} 
"Pode-se conceituar a discriminação positiva como políticas, de caráter temporário ou definitivo, concebidas tanto pelo poder público como pela iniciativa privada, de forma compulsória ou voluntária, direcionadas para uma determinada parcela da população excluída socialmente, em função de sua origem, raça, cor, gênero, compleição física ou mental, idade, etnia, opção sexual, religião, ou condição econômico-social, as quais objetivam corrigir ou, ao menos, minimizar as distorções ocorridas no passado e propiciar a igualdade de tratamento e de oportunidades no presente, em especial as relacionadas às áreas da educação, da saúde e do emprego.” (2005, p.62)

Ou seja, não há como se construir uma sociedade com igualdade de fato sem uma atuação direta do Estado visando promovê-la, mais do que um princípio norteador das suas atuações, mas compreendendo que políticas públicas são essenciais. Uma vez que a sociedade, a soberania popular, como poder constituinte originário dispôs assim, portanto, este é um anseio geral que deve ser correspondido pelo Poder Executivo, quem tem o poderdever de atuar mais diretamente neste sentido. Assim assinala J. J. Gomes Canotilho:

"O princípio da igualdade é não apenas um princípio de Estado de direito mas também um princípio de Estado social. Independentemente do problema da distinção entre "igualdade fática" e "igualdade jurídica" e dos problemas econômicos e políticos ligados à primeira (ex.: políticas e teorias da distribuição e redistribuição de rendimentos), o princípio da igualdade pode e deve considerarse um princípio de justiça social. Assume relevo enquanto princípio de igualdade de oportunidades e de condições reais de vida. Garantir a liberdade real ou liberdade igual é o propósito de numerosas normas e princípios consagrados na Constituição." (2003, p. 430)

Neste entendimento é que podemos afirmar que o conceito de igualdade está diretamente ligado à justiça social, requerendo políticas que conduzam a uma sociedade verdadeiramente igualitária, na qual se concretizam os dispostos constitucionais como ideias vinculativas de todos os atos sob aquela jurisdição constitucional, correspondendo à efetividade dos direitos sociais.

Uma vez consagrado no artigo $3^{\circ}$, inciso $\mathrm{IV}^{5}$ o dever de promoção da igualdade, fator inerente a dignidade da pessoa humana, este não serve de

\footnotetext{
5 “Art. $3^{\circ}$ Constituem objetivos fundamentais da República Federativa do Brasil: I - construir uma sociedade livre, justa e solidária; II - garantir o desenvolvimento nacional; III - erradicar a pobreza e a marginalização e reduzir as desigualdades sociais e regionais; IV - promover o bem de todos, sem preconceitos de origem, raça, sexo, cor, idade e quaisquer outras formas de discriminação." (Brasil, Constituição Federal 1988)
} 
base apenas para fundamento de combate a discriminação negativa, mas mais do que letra, é premissa impositiva, sob a qual devem estar todos os atos de governo, estando suscetível a inconstitucionalidade por omissão (Canotilho, 2003, p. 430) se não houverem atos visando promover a compensação da desigualdade.

Deste modo, podemos afirmar que a garantia de direitos a parte da população mais vulnerável é garantir direitos de todos, pois assim se constrói um Estado democrático. A consagração da igualdade requer soluções materiais diferentes, sem as quais não se pode dizer que o indivíduo está livre para o desenvolvimento pleno de sua personalidade e a uma vida com garantia do mínimo existencial.

Acreditamos que isto representa os direitos sociais. Não devem ser compreendidos como em oposição às liberdades individuais, mas como garantidores dela, devem ser complementares. A distinção entre direitos fundamentais de primeira geração, relativos à liberdade da pessoa, e de segunda geração, relativos à garantia de igualdade social, não cabe em relação a direitos sociais, pois para se afirmar a liberdade, faz-se necessário prover condições materiais que o tornem de fato apto a ser livre. Sendo assim, a busca por um direito social efetivo está relacionada às máximas de liberdade e de igualdade. Logo, é um ganho de toda a sociedade.

É o entendimento de Afonso Arinos de Melo Franco ${ }^{6}$ que os direitos sociais seriam oponíveis a sociedade como um todo e não ao Estado, entretanto concebemos que ao afirmar isto o autor não tem entendimento conflituoso com o que dissemos acima, mas sim que o exercício de direitos sociais é essencial a sociedade como um todo, não apenas àquele que

\footnotetext{
6 “O que nos parece evidente, da observação das doutrinas e práticas constitucionais dos Estados totalitários recentes (Rússia, Alemanha nazista, Itália fascista ou Repúblicas Populares), é que o abandono, por êles, das garantias referentes à segurança e à liberdade do indivíduo, representa um processo mais geral e profundo do que o interesse imediato das ditaduras. Representa o abandono da teoria dos direitos públicos individuais por uma outra que seria a teoria dos direitos sociais do indivíduos. Segundo nossa interpretação, tais direitos não seriam oponíveis ao Estado mas à sociedade, e garantiriam o indivíduo, não em função dos atributos da sua personalidade, mas como parte integrante do grupo social. Neste sentido é que devem ser entendidos, a nosso ver, os direitos ao trabalho, à educação, ao salário justo, à habitação, ao repouso, enfim todo o conjunto dos direitos vulgarmente chamados sociais." (Franco, 1958, p.181)
} 
postula, desta forma toda a sociedade tem seu papel na promoção dos direitos sociais e o Estado tem papel fundamental de garantidor de condições adequadas.

Quando na Carta Magna, a mais alta representação da vontade popular, está disposto que "são direitos sociais a educação, a saúde, a alimentação, o trabalho, a moradia, o transporte, o lazer, a segurança, a previdência social, a proteção à maternidade e à infância, a assistência aos desamparados, na forma desta Constituição" (Brasil, Constituição Federal de 1988 , art. $6^{\circ}$ ), é ao mesmo tempo o reconhecimento de que existe uma carência social a ser cumprida.

Dos direitos fundamentais sociais decorrem a proteção do indivíduo vulnerável, a qual deve corresponder à dignidade da pessoa humana, direitos garantidores da vida, e vida digna; defesa de sua liberdade, dada a impossibilidade do indivíduo de prover por conta própria; prestação social, pois o gozo depende de intervenção estatal; e sua proteção contra discriminação negativa, visto que esta categoria de direitos confere ao indivíduo o poder jurídico de exigir seu direito. Por fim, direito social é o individuo empoderado pelo direito.

Por conseguinte, há que se ter em mente que as prestações estatais não constituem favores aos seus destinatários, todavia o desenvolvimento da personalidade só é possível se a dignidade da pessoa for assegurada, conjugando interesse individual e social, prestações, liberdade e igualdade.

Há quem defenda que o direito social representa um risco ao Direito Público, mesmo que se fundamente na justiça, conforme faz alusão Afonso Arinos de Melo Franco:

\footnotetext{
"Não há dúvida que a reivindicação de tais direitos se assenta na justiça. O grande problema da nossa geração está. Porém, em garantir-se o Direito social individual, sem sacrifício do que existe de verdadeiramente básico no Direito público individual. Problema, em verdade, formidável, mas que precisa ser resolvido, porque só a sua solução pode assegurar o equilíbrio entre justiça e liberdade. Para nós, esta solução deve ser procurada nos rumos traçados pela democracia cristã, únicos capazes de enfrentar os males do capitalismo, sem cair nos riscos do comunismo." (Franco, 1958, p.181)
} 
No entanto, o entendimento de que estes direitos estariam em conflito com os demais já foi vencido. O direito fundamental social corresponde ao direito do particular que não detém meios financeiros suficientes ou não houver resposta satisfatória do mercado quando à procura dos bens sociais (saúde, educação, segurança social), a obtê-los através do Estado.

J. J. Gomes Canotilho apresenta, ainda outra problemática que poderia envolver os direitos sociais, associados a sua função (2003, p. 408, 409):

a) o problema dos direitos sociais originários: se os particulares exigirem seus direitos diretamente do que está disposto na norma constitucional, por exemplo, se há consagrado o direito a moradia e é interpretado como direito de exigir uma casa;

b) o problema dos direitos sociais derivados: se os particulares exigirem atuação legislativa para materializar o dispositivo constitucional sob pena de incorrer em inconstitucionalidade por omissão;

c) o problema de saber se as normas que consagram direitos fundamentais são vinculativas juridicamente dos poderes públicos: se os direitos sociais exigem, por si só, políticas sociais ativas conduzindo a criação de instituições e prestação de serviços, pelo Poder Público.

Finalmente, podemos considerar que as duas primeiras problemáticas apresentadas podem ser abarcadas ou derrubadas de acordo com o caso concreto, se houver na norma determinação de criação de Lei regulamentadora que garanta o exercício deste direito social e esta não for criada, aí sim será cabível a inconstitucionalidade por omissão ${ }^{7}$ ou se numa cidade inteira não houver um hospital para atender a população, aí sim será

\footnotetext{
7 "Declarada a inconstitucionalidade por omissão de medida para tornar efetiva norma constitucional, será dada ciência ao Poder competente para a adoção das providências necessárias e, em se tratando de órgão administrativo, para fazê-lo em trinta dias." (Brasil, Constituição Federal de 1988, art. 103, § $2^{\circ}$ ).
} 
exigível a criação de um, com base somente neste direito. E quanto a última questão, é claro e evidente que as normas constitucionais consagradoras de direitos sociais impõem políticas públicas efetivas. 


\section{DAS PESSAS SURDAS}

"Recuso-me a ser considerada excepcional, deficiente. Não sou. Sou surda. Para mim, a língua de sinais corresponde à minha voz, meus olhos são meus ouvidos. Sinceramente nada me falta. É a sociedade que me torna excepcional..."

(Vôo da gaivota; Emmanuelle Laborit).

A pessoa surda é a pessoa principal neste trabalho, portanto é de suma importância compreender quem é esta pessoa. Diferentemente do uso popular, o surdo não se confunde com o mudo, bem como não se confunde com o deficiente auditivo ou o portador de necessidades especiais, logo as terminologias "surdo-mudo", "deficiente auditivo" e "portador de necessidades especiais", dentre outras formas, inclusive pejorativas, usualmente ditas popularmente demonstram-se inadequadas para identificar a pessoa de direitos surda a qual é o foco deste estudo.

Sendo assim, dedicaremos este capítulo à compreensão de quem é a pessoa surda e as diferenças fundamentais do conceito original de surdez para o conceito popular, esclarecendo a que categorias de pessoas se refere cada uma destas terminologias. E tentar compreender o ser surdo.

O Decreto $\mathrm{n}^{\mathbf{o}} 3.298$, de 20 de dezembro de 1999, numa tentativa de definição falhou em diversos aspectos:

"Art. $3^{\circ}$. Para os efeitos deste Decreto, considera-se:

I - deficiência - toda perda ou anormalidade de uma estrutura ou função psicológica, fisiológica ou anatômica que gere incapacidade para o desempenho de atividade, dentro do padrão considerado normal para o ser humano;

II - deficiência permanente - aquela que ocorreu ou se estabilizou durante um período de tempo suficiente para não permitir recuperação ou ter probabilidade de que se altere, apesar de novos tratamentos; e

III - incapacidade - uma redução efetiva e acentuada da capacidade de integração social, com necessidade de equipamentos, adaptações, meios ou recursos especiais para que a pessoa portadora de deficiência possa receber ou transmitir informações necessárias ao seu bem-estar pessoal e ao desempenho de função ou atividade a ser exercida." (Brasil, 1999) 
Cumulado com o artigo $4^{\circ}$ do mesmo Decreto que contém a tentativa de definição de deficiência auditiva:

“Art. $4^{\circ}$. É considerada pessoa portadora de deficiência a que se enquadra nas seguintes categorias:

[...]

II - deficiência auditiva - perda bilateral, parcial ou total, de quarenta e um decibéis $(\mathrm{dB})$ ou mais, aferida por audiograma nas frequiências de $500 \mathrm{HZ}$, $1.000 \mathrm{HZ}, 2.000 \mathrm{~Hz}$ e $3.000 \mathrm{~Hz}$;

[...]" (Ibid., 1999)

É considerada inadequada a redação destes dispositivos tendo em vista a forte carga pejorativa que tem o termo "anormalidade" utilizado, pois traz a ideia de que a pessoa com deficiência não é normal, em detrimento de suas demais capacidades que não são anuladas por seu impedimento sensorial, físico ou intelectual.

Além disso, esta classificação não serve para a pessoa surda, porquanto deficiência representa uma insuficiência da função, logo, o deficiente auditivo é aquele que apresenta insuficiência na função auditiva, porém aquele que não tem a função auditiva, não pode apresentar insuficiência do que não tem. E ainda não é apropriado este termo, porque deficiência sugere imperfeição, pois o contrário de deficiência não é eficiência, mas sim, sem deficiência, e não há uma só pessoa que seja completamente perfeita ou mesmo que seja completamente imperfeita.

Também foi mal empregada a expressão "portadora de deficiência", pois o verbo portar significa transportar, levar consigo algo, ou trajar algo, ou comportar-se de certa forma, sendo certo que uma deficiência não é algo que se possa conduzir até determinado local e depois abandonar, ou algo que se possa vestir e a qualquer tempo se despir dela, nem mesmo algo que represente apenas um comportamento, que possa posteriormente ser readequado.

Além de que a definição de incapacidade trazida pelo dispositivo revela um aspecto social e não apenas relativo ao corpo com impedimentos, uma vez que o que poderia impossibilitar ou dificultar a integração social de alguém não é seu próprio corpo, mas a discriminação negativa. O que 
mostra que ainda nesta altura da história do Brasil o corpo com impedimentos era visto como uma desvantagem social ${ }^{8}$.

E necessidades especiais não dizem muito sobre quem é a pessoa, não diz se é uma pessoa com impedimentos ou não, visto a abrangência deste termo. Qualquer pessoa pode ter uma necessidade especial, por exemplo, uma criança, um idoso, uma pessoa que sofreu alguma lesão e está em recuperação. Além de existirem necessidades especiais de diversos âmbitos, como financeiro, social, turístico etc.

Melhor é a definição trazida pelo Decreto $\mathrm{n}^{\circ}$. 5.626, de 22 de dezembro de 2005, que regulamentou o Decreto supramencionado, cuja definição apresentada qualifica a pessoa surda e o deficiente auditivo:

"Art. $2^{\circ}$. Para os fins deste Decreto, considera-se pessoa surda aquela que, por ter perda auditiva, compreende e interage com o mundo por meio de experiências visuais, manifestando sua cultura principalmente pelo uso da Língua Brasileira de Sinais - Libras.

Parágrafo único. Considera-se deficiência auditiva a perda bilateral, parcial ou total, de quarenta e um decibéis $(\mathrm{dB})$ ou mais, aferida por audiograma nas freqüências de $500 \mathrm{~Hz}, 1.000 \mathrm{~Hz}, 2.000 \mathrm{~Hz}$ e $3.000 \mathrm{~Hz}$.” (Id., 2005)

Neste entendimento, ser surdo, mais do que a perda auditiva total, denota a inserção numa cultura e língua próprias. E daí decorre a importância de a criança surda ter contato com a Libras, tão logo, para que ela possa ter um desenvolvimento linguístico, sem isto seu progresso fica comprometido, uma vez que sua língua materna será a base para o aprendizado das demais coisas, incluindo a língua escrita, ou até mesmo a língua oral. É o que nos esclarece Lucinda F. Brito:

\footnotetext{
${ }^{8}$ Sobre isso, é de grande valia a contribuição do artigo Deficiência, Direitos Humanos e Justiça da SUR - Revista Internacional de Direitos Humanos:

"A normalidade, entendida ora como uma expectativa biomédica de padrão de funcionamento da espécie, ora como um preceito moral de produtividade e adequação às normas sociais, foi desafiada pela compreensão de que deficiência não é apenas um conceito biomédico, mas a opressão pelo corpo com variações de funcionamento. A deficiência traduz, portanto, a opressão ao corpo com impedimentos: o conceito de corpo deficiente ou pessoa com deficiência devem ser entendidos em termos políticos e não mais estritamente biomédicos.

Essa passagem do corpo com impedimentos como um problema médico para a deficiência como o resultado da opressão é ainda inquietante para a formulação de políticas públicas e sociais (Diniz, 2007, p. 11). Deficiência não se resume ao catálogo de doenças e lesões de uma perícia biomédica do corpo (Diniz et. al, 2009, p. 21) é um conceito que denuncia a relação de desigualdade imposta por ambientes com barreiras a um corpo com impedimentos." (Diniz et. al, 2009, p. 65)
} 
"Se a socialização da criança se dá desde sua mais tenra idade, decorre daí que a língua dos sinais é imprescindível ao surdo, mesmo que este, no início, esteja limitado à comunicação apenas com aqueles que manipulem bem esta língua ou que se iniciem no seu aprendizado. Posteriormente, em contato com a língua oral, sua segunda língua, terá alcançado maior aptidão em todos os níveis (psicológico, cognitivo, social e linguístico) para enfrentar a árdua tarefa de seu aprendizado. O surdo já terá tido a prática de socialização através da língua dos sinais, suporte para o aprendizado da língua oral, vale dizer, terá já estabelecida uma comunicação gratificante.” (Brito, 1986, p. 19)

Ainda há outras expressões frequentemente utilizadas na sociedade, os termos "surdo-mudo" e "mudo", pelo fato de as pessoas surdas de nascença $^{9}$ não terem desenvolvido a fala por meio da voz. Estas terminologias também estão incorretas para identificar a pessoa surda, pois a limitação sensorial auditiva nada tem a ver com a limitação da fala. A mudez está associada a perda da voz, quando ocorre o dano funcional permanente de algum dos órgãos do aparelho fonador, estes que não estão associados ao sistema auditivo do corpo humano, assim o surdo tem voz e pode emitir sons diferentemente do mudo. A maioria dos surdos não apresentam as duas limitações.

Embora a alteração do artigo $4^{\mathrm{o}}$, inciso $\mathrm{II}^{10}$, do Decreto $\mathrm{n}^{\mathrm{o}} .3 .298$ de 1999 pelo Decreto ${ }^{\circ}$. 5.296 de 2004 tenha desconsiderado as classificações de surdez e a surdez leve, o Manual de Legislação em Saúde da Pessoa com Deficiência, do Ministério da Saúde, apresenta ainda graus de surdez conforme a perda auditiva - que se afere por meio de audiometria - e dá as principais causas da surdez (uma vez que não é condição necessária de quem tem ascendentes surdos):

\footnotetext{
${ }^{9}$ Já que a surdez pode ser pré ou pós-lingual. A surdez pré-lingual, faz com que a pessoa nunca tenha desenvolvido nenhum sistema linguístico, por exemplo, a criança que nasce com surdez profunda; daí a importância da Libras, como já mencionado acima. E quando a surdez é póslingual haverá um sistema de adaptação, visto que nestas condições a Libras torna-se o mais eficaz no desenvolvimento linguístico. Porém, será de escolha do surdo capaz ou de seus familiares, se incapaz, a escolha pela utilização da Libras ou o incentivo a oralização, mesmo que a Libras como primeira língua também dê base para aquisição de uma segunda língua.

${ }^{10}$ Era a antiga redação do dispositivo mencionado:

"Art. $4^{\underline{0}}$ É considerada pessoa portadora de deficiência a que se enquadra nas seguintes categorias: [...] II - deficiência auditiva - perda parcial ou total das possibilidades auditivas sonoras, variando de graus e níveis na forma seguinte: a) de 25 a 40 decibéis (db) - surdez leve; b) de 41 a 55 db surdez moderada;

c) de 56 a $70 \mathrm{db}$ - surdez acentuada; d) de 71 a $90 \mathrm{db}$ - surdez severa; e) acima de $91 \mathrm{db}$ - surdez profunda; e f) anacusia; [...]" (Brasil, Decreto n'. 3.298, de 20 de dezembro de 1999, art. 4º II, redação anterior à alteração de 2004)
} 


\begin{abstract}
"A deficiência auditiva, caracterizada pela perda total ou parcial da capacidade de ouvir, manifesta-se como surdez leve e moderada, e surdez severa ou profunda. Assim como na visual, as pessoas portadoras de deficiência auditiva podem ser afetadas na sua aprendizagem e no seu desenvolvimento integral. A estimativa da OMS, em 1993, é de que $1,5 \%$ da população brasileira - cerca de 2.250 .000 habitantes - seria portadora dessa deficiência. As causas de deficiência auditiva, de moderada a profunda, mais freqüente em crianças, são a rubéola gestacional e outras infecções pré-natais. Contudo, em cerca de $33 \%$ dos casos não se consegue estabelecer uma etiologia para essa afecção. Nos casos de deficiência auditiva de leve a moderada, a otite média é a causa mais frequente na infância, com uma incidência ao redor de 33\%." (Brasil, Ministério da Saúde, p. 16, 17)
\end{abstract}

Os tipos de surdez que tratamos no presente trabalho são a severa, na qual "a criança já tem muitas dificuldades em adquirir fala e linguagem de forma espontânea e, em contexto familiar, pode vir a desenvolver algum vocabulário e necessitar do uso de aparelho" (Novaes, 2014, p. 46); e profunda, quando "dificilmente a criança conseguirá desenvolver uma linguagem oral de forma concedida, só percebe sons intensos, como trovões, bombas, avião, e, quase sempre, faz uso da leitura orofacial, necessitando de aparelhos e de implantes cocleares ${ }^{11 "}$ (Ibid., 2014, p. 46). Há ainda o tipo de surdez congênita, que se dá pela má formação do sistema auditivo fazendo com que o nervo auditivo seja ausente. Nestas pessoas nem mesmo o implante coclear seria eficiente para desenvolver a audição e, portanto, não ouvirão.

\title{
Oliver Sacks tenta descrever como é ser surdo neste contexto:
}

“A situação é muito diversa, e essencialmente inimaginável pelas pessoas normais (e até mesmo pelas que têm surdez pós-linguística, [...]), quando já ao nascer a audição está ausente ou quando ela é perdida na infância antes de a língua ser adquirida. As pessoas assim atingidas - com surdez pré-linguística encontram-se numa categoria qualitativamente diferente de todas as demais. Para essas pessoas, que nunca ouviram, que não têm lembranças, imagens ou associações auditivas possíveis, nunca poderá ocorrer a ilusão de som. Elas vivem num mundo de absoluto e contínuo silêncio e ausência de som." (Sacks, 2010, p. 12)

Há no Brasil, segundo o IBGE, Censo Demográfico 2010, cerca de $5,1 \%$ de pessoas com deficiência auditiva. Sendo as consideradas severa, ou

\footnotetext{
${ }^{11}$ Implante coclear é um dispositivo eletrônico inserto por meio de procedimento cirúrgico, que proporciona ao implantado a função auditiva, porém que não se iguala a função natural e não tem utilidade para pessoas que não têm o nervo auditivo devido a surdez congênita.
} 
seja, com grande dificuldade de ouvir ou que não conseguem ouvir, $0,9 \%$ no norte; $1,2 \%$ no nordeste; $1,1 \%$ no sudeste; $1,2 \%$ no sul e $1,0 \%$ no centrooeste do país.

Por não compreender o que é ser surdo, muitas vezes os pais, responsáveis, profissionais da saúde ou instituições de ensino entendem que a melhor maneira de educação do surdo é impelindo-o a falar utilizando suas cordas vocais ao invés de suas mãos. Compreendem que sua integração social dependerá do desenvolvimento da fala, porém o que ocorre é a opressão de toda uma cultura e identidade do ser surdo. Conforme defende Lucinda F. Brito:

\begin{abstract}
"As línguas gestuais-visuais são a única modalidade de língua que permite aos surdos desenvolver plenamente seu potencial linguístico e, portanto, seu potencial cognitivo, oferecendo-lhes, por isso mesmo, possibilidade de libertação do real concreto e de socialização que não apresentaria defasagem em relação àquela dos ouvintes. São o meio mais eficiente de integração social do surdo.” (Brito, 1986, p. 21)
\end{abstract}

Vale ainda citar Emmanuelle Laborit, escritora e atriz, francesa, surda, que em sua biografia nos descreve como é ser surda em meio a uma sociedade que não compreende sua cultura e língua próprios:

\footnotetext{
'Sou surda não quer dizer: 'Não ouço.', Quer dizer: 'Compreendi que sou surda.' É uma frase positiva e determinante. Na minha mente, admito que sou surda, compreendo-o, analiso-o, porque me deram uma língua que me permite fazê-lo. Compreendo que os meus pais têm a sua própria língua, a sua maneira de comunicar e que eu tenho a minha. Pertenço a uma comunidade, tenho uma verdadeira identidade. Tenho compatriotas." (Laborit, 2000, p. 48)

Muitas crianças surdas nascem em contexto familiar de ouvintes, que não compreendem que a língua de sinais é a língua materna de seus filhos e têm dificuldades de aceitá-la. Acreditam que a língua oral deve ser estimulada em detrimento da língua de sinais, o que causa a exclusão da criança dos ambientes de conversa (Choi et. al., 2011, p. 26) e pode representar para ele um ambiente de opressão, no qual ele não tem oportunidade de se expressar. Sobre isso, diz Laborit:
} 
"Creio que os adultos que ouvem e que privam os filhos da língua gestual nunca conseguirão compreender o que se passa na cabeça de uma criança surda. Há a solidão e a resistência, a sede de comunicar e por vezes a ira.

A exclusão na família, em casa, onde toda a gente fala sem se preocupar conosco. Porque é preciso perguntar todo o tempo, puxar alguém pela manga ou pelo vestido para saber um pouco, um bocadinho, do que se passa à nossa volta. Senão, a vida não é mais do que um filme mudo, sem legendas." (2000, p. 42)

Diz ainda a autora:

"Somos uma minoria, os surdos profundos de nascença. Com uma cultura específica e uma língua específica. Os médicos, os investigadores, todos os que querem transformar-nos a qualquer preço em ouvintes põem-me os cabelos em pé. Fazerem-nos ouvintes é aniquilar a nossa identidade. Querer que à nascença deixe de haver crianças 'surdas', é desejar um mundo perfeito. Como se quiséssemos que fossem todos louros, com olhos azuis, etc.” (Ibid., 2000, p. 126)

No Brasil, a língua materna dos surdos é chamada de Língua Brasileira de Sinais ${ }^{12}$. A língua de sinais nasce e se propaga por meio da comunidade surda, portanto reflete um aspecto cultural da população surda local, representa sua identidade, e por isso a definição de "linguagem" é insuficiente para a Libras, que tem toda uma estrutura gramatical própria de uma língua, apesar das diferenças da língua oral, conforme esclarece o trecho a seguir:

\begin{abstract}
“Apesar das diferenças existe entre línguas de sinais e línguas orais, ambas seguem os mesmos princípios com relação ao fato de que têm léxico, isto é, um conjunto de símbolos convencionais, e uma gramática, ou seja, um sistema de regras que rege o uso e a combinação desses símbolos em unidades maiores." (Choi et. al., 2011, p. 5)
\end{abstract}

Entretanto, a principal diferença que a língua de sinais apresenta da língua oral é que são de modalidade visual-espacial, ou gestual-visual, pois a informação é recebida pelos olhos e é produzida no espaço. Um sinal na Libras é formado a partir de cinco parâmetros: configuração das mãos (que corresponde a forma feita pela mão); localização (que corresponde ao ponto de articulação do corpo onde o sinal é feito); movimento (que corresponde a

\footnotetext{
${ }^{12}$ Cabe esclarecer que diferentemente do que comumente se pensa, a língua de sinais não é universal, por isso no Brasil chamamos de Língua Brasileira de Sinais, porque reflete a cultura do povo surdo brasileiro. Assim como cada país tem sua língua de sinais, por exemplo, nos Estados Unidos da América há a American Sign Language - ASL, na França há a Langue des Signes Française - LSF etc. E, bem como na língua falada temos sotaques e expressões que correspondem a um estado da federação, regionalismos, na Libras também temos sinais regionais.
} 
forma como mexe a mão fazendo o sinal, como direção, pulso etc.); orientação das palmas das mãos (que corresponde a direção que aponta a palma da mão fazendo o sinal); traços não manuais (que correspondem a expressão facial e/ou movimento do corpo).

A língua é um veículo de comunicação por excelência e a principal forma de identificação do indivíduo com sua cultura, "a língua de sinais é a manifestação da diferença lingüística-cultural relativa aos surdos" (Strobel, 2009, p. 32). As grandes dificuldades que enfrentam as minorias linguísticas são a restrição da língua materna e, em decorrência disto, de sua identidade cultural.

Não obstante, a cultura também é um direito protegido constitucionalmente, "é importante ter isso em mente, porque a Constituição não ampara a cultura na extensão de sua concepção antropológica, mas no sentido de um sistema de referência à identidade, à ação, à memória dos diferentes grupos formadores da sociedade brasileira (art. 216)" (Silva, J. A., 2001, p. 35).

Os surdos brasileiros são parte do processo de formação da cultura brasileira, portanto, a cultura que produzem faz parte do enriquecimento do país, a medida em que a diversidade enriquece a cultura e o Estado deve garantir a todos o pleno exercício dos direitos culturais, apoiando e incentivando a valorização e difusão das manifestação culturais (Brasil, Constituição Federal, art. 215).

José Afonso da Silva, em poucas palavras define o processo de criação cultural:

"Criar cultura, no fundo, consiste em transformar realidades naturais ou sociais, mediante a impregnação de valores; e, como estes são de vários tipos, daí surgem os correspondentes objetos de cultura: a) valores vitais - dão origem aos modos de viver e cultivar o corpo, o bem-estar; b) valores de utilidade - dão origem a modos de criar e fazer, surgindo daí objetos culturais materiais: tipos de comida, habitação, objetos domésticos, vestuário, instrumentos de sua criação, utensílios (garfo, colher, faca etc.) e ferramentas; c) valores espirituais: - estéticos - criam objetos culturais artísticos pela Pintura, Escultura, Arquitetura, Música, Dança etc.; religiosos - criam objetos culturais sagrados; éticos (morais, jurídicos) criam modos de comportamento e de conduta necessários à convivência social." (Silva, J. A., 2001, p.32, 33) 
Os surdos o fazem por meio da comunidade surda, espaços onde surdos desenvolvem atividades que lhes interessam, como associações e clubes e também no qual resistem às práticas de imposição cultural do ouvinte. É o espaço no qual, diferentemente do contexto social, pode ser livre em sua linguística e valores culturais. No âmbito desta comunidade "compartilham valores, crenças, comportamentos e, o mais importante, uma língua diferente da utilizada pelo restante da sociedade" (Choi et. al., 2011, p. 34).

Este é um dos mais importantes meios de integração social do surdo, já que é também por meio da comunidade surda, muitas vezes, que o surdo vai tomar conhecimento dos principais fatos que acontecem no mundo, "pertencer à comunidade surda pode ser definido pelo domínio da língua de sinais e pelos sentimentos de identidade grupal, fatores que consideram a surdez como uma diferença, e não como uma deficiência" (Choi et. al., 2011, p. 34), e neste ambiente não são há espaço para diferenciação entre graus de perda auditiva, mas todos aqueles que compartilham deste sentimento são bem vindos.

São algumas das produções culturais surdas (à título de exemplificação e não taxatividade): valores, principalmente o de que surdez não é uma vergonha; costumes; expressões artísticas, como brincadeiras, poesia, histórias de surdos, piadas, literatura infantil, fábulas e contos clássicos adaptados, lendas, dentre outras; aparelhos tecnológicos adaptados, como campainhas luminosas, relógio de pulso vibratório, aplicativos de tradução, dentre outros.

\subsection{Modelos Educacionais para Surdos}

Helena Singer, falando sobre o princípio constitucional da gestão democrática do ensino público (art. 206, VI, da CRFB/88) defende que "seu princípio fundamental era de que o educador não deveria se sobressair em relação ao educando, deveria sempre levar a sério sua opinião, seu ponto de 
vista, porque desfazê-lo seria doloroso para a criança, oprimiria sua personalidade e seu amor próprio" (Koerner et al., 2005, p. 184).

Ao oferecer abaixo uma visão geral dos modelos educacionais mais comuns na educação de surdos é possível uma breve análise do modelo que mais se adéqua a esta concepção, aquele que não ampara que educadores ouvintes se sobreponham a alunos surdos, mas que se atentem às suas necessidades e estimulem a autoestima.

A educação não pode ser um processo seletivo ${ }^{13}$, mas um processo para o desenvolvimento de toda a população. Não deve servir para a perpetuação das desigualdades, esta não é a finalidade da educação, mas sim para a construção das igualdades de condições. E para isso o modelo educacional mais adequado a gerar estes efeitos na população surda é o que deve ser adotado. Vejamos abaixo:

ORALIZAÇÃO: Esta metodologia recusa a língua de sinais, defende que a comunicação dos surdos deve se dar apenas pelo modo oral. No II Congresso Internacional de Educação do Surdo de 1880, que ocorreu em Milão, concluiu-se que a educação de surdos deveria se dar exclusivamente por este método, assim, muitos educadores surdos foram dispensados de seus cargos. Porém a proibição do uso da língua de sinais pelos surdos resultou em baixo rendimento escolar, como já esperado por muitos, não por incapacidade de absorção do conhecimento dos alunos surdos, mas por incapacidade do método de transferir conhecimento.

Este modelo ainda é adotado hoje por muitas instituições de ensino com classes ditas de "inclusão" (ou integração). Laborit descreve como foi sua experiência numa escola onde se adotava o método de oralização:

'Na escola não gosto das professoras da classe dita de 'integração'. Querem que eu me assemelhe às crianças que ouvem, impedem-me de fazer gestos, obrigamme a falar. Com elas fico com a sensação de que é preciso esconder que se é

\footnotetext{
${ }^{13}$ Concepção trazida por Anísio Teixeira, o qual aduz: "Mas, se tomarmos o ponto de vista de que o processo educativo é um processo seletivo, destinado a retirar da massa alguns privilegiados para uma vida melhor, que se fará possível exatamente porque muitos ficarão na massa a serviço dos 'educados', então o sistema funciona, exatamente por não educar todos mas somente uma parte." (Teixeira, 1999, p. 51)
} 
surdo, imitar os outros como um pequeno robô, quando afinal não percebo metade do que se diz na aula." (Laborit, 2000, p. 43)

A experiência nos mostra que suprimir a língua visual-gestual é tentar apagar toda uma identidade, não deve ser uma imposição falar como os ouvintes, isto seria como dizer que a língua de sinais é inferior. Revela claramente o que Edmarcius C. Novaes chama de "etnocentrismo oralista em relação às pessoas surdas", este modelo os vê como quem vivencia uma patologia que necessita de apoio de especialistas que os ensine a ouvir (Novaes, 2014, p. 83), geralmente chamados de política de inclusão, porém que ocorre é o contrário:

\footnotetext{
"Os educadores não se debruçam em um processo de vital importância de se formar a Identidade e Cultura Surda para os próprios surdos, o que implica suas condições de cidadãos éticos, críticos, além de estar ferindo o conceito de equidade e dignidade humana, pois, mesmo com o viés de buscar a igualdade, resultam, na realidade, na eliminação da latente diferença linguística e cultural existente". (Novaes, 2014, p.84)
}

Este modelo acaba por causar a exclusão do aluno surdo em uma sala de aula com ouvintes. Não se atenta ao fato de que a surdez não é uma deficiência como as demais, por isto não funciona a adaptação do surdo ao contexto de ouvintes, é necessário uma metodologia de ensino distinta, que atenda às suas necessidades, que propicie seu progresso psicológico e intelectual.

COMUNICAÇÃO TOTAL: Este modelo surgiu em 1960 após constatado fracasso do modelo anterior. A comunicação total também defende o aprendizado da língua oral pelos surdos, porém isto se daria pela leitura orofacial (vulgarmente chamada de "leitura labial") e complementar aprendizado da língua de sinais, assim o surdo deveria se expressar tanto por meio da voz quanto por meio da língua visual-espacial.

A principal filosofia deste método é proporcionar ao surdo possibilidades em ambas as formas de comunicação, o uso concomitante de ambas as línguas, porém com a estrutura gramatical da língua dos ouvintes.

Mesmo que este método estimule também a língua de sinais, esta metodologia por vezes pode se demonstrar inadequada porque não favorece 
a construção do equilíbrio psicológico e intelectual das crianças surdas, dá aos ouvintes a liberdade de gerir a comunidade de surdos, estabelecendo a sua língua como prioritária, inclusive adaptando a língua de sinais à estrutura gramatical da língua oral.

BILINGUISMO: Quando em 1980 a comunidade surda passou a exigir o reconhecimento da língua de sinais, sendo passível de ser usada na educação de crianças surdas, reivindicando reconhecimento de sua cultura e o direito de transmiti-la às crianças surdas (Choi et. al., 2011, p. 12), surgiu esta metodologia.

O bilinguismo defende um modelo educacional para os surdos que privilegia duas línguas: “a primeira, a língua de sinais, dá o arcabouço para o aprendizado da segunda, a língua majoritária - preferencialmente na modalidade escrita" (Choi et. al., 2011, p. 12).

Este método proporciona à criança surda a identificação com a cultura surda e a construção de sua identidade, proporcionando seu desenvolvimento nos mais diversos aspectos de seu ser. E para isso, a criança surda precisa estar em contato com adultos surdos, essa é também a importância de se ter educadores surdos.

Nos reportaremos mais uma vez aos escritos de Laborit, que nos esclarece como é ser uma criança surda com pais ouvintes (como acontece na maioria dos casos das crianças surdas) e a diferença que fez em sua vida o contato com um adulto surdo:

\footnotetext{
"Eu, que me julgava única e destinada a morrer criança, como imaginam tantas crianças surdas, descubro que tenho um futuro possível, uma vez que Alfredo é adulto e surdo.

Esta lógica cruel dura enquanto as crianças surdas não se cruzam com um adulto surdo. Necessitam dessa identificação com o adulto, necessitam de forma crucial. É preciso convencer todos os pais de crianças surdas que têm que as pôr em contacto com adultos surdos o mais cedo possível, desde a nascença." (Laborit, 2000, p. 34, 35)
}

Não ter contato com adultos surdos pode ensejar um atraso no aprendizado da criança surda, uma vez que isto é parte de seu processo de aquisição de conhecimento neste método. No bilinguismo a língua tem o 
status de meio fundamental à comunicação de pessoas surdas e favorece a expansão da capacidade cognitiva do educando. Oliver Sacks ressalta a essencialidade da plena aquisição da língua:

\begin{abstract}
"E ser deficiente na linguagem, para um ser humano, é uma das calamidades mais terríveis, porque é apenas por meio da língua que entramos plenamente em nosso estado e cultura humanos, que nos comunicamos livremente com nossos semelhantes, adquirimos e compartilhamos informações. Se não pudermos fazer isso, ficaremos incapacitados e isolados, de um modo bizarro - sejam quais forem nossos desejos, esforços e capacidades inatas. E, de fato, podemos ser tão pouco capazes de realizar nossas capacidades intelectuais que pareceremos deficientes mentais." (Sacks, 2010, p. 12)
\end{abstract}

\title{
2.2. Instituições Importantes na Educação de Surdos no Rio de Janeiro
}

INSTITUTO NACIONAL DE EDUCAÇÃO DE SURDOS - INES: Este instituto foi criado no século XIX por E. Huet, surdo, francês, e se chamava Collégio Nacional para Surdos-Mudos, de ambos os sexos.

Atualmente o INES é instituição referência na educação (oferecendo da educação infantil até o ensino médio), profissionalização e socialização de surdos em todo o território brasileiro e na América Latina, pois é a única instituição de âmbito federal de educação de surdos desta circunscrição.

Conta com equipe multidisciplinar dedicada a pesquisa de novas metodologias de ensino da pessoa surda. Também tem profissionais surdos e os forma, além de oferecer graduação bilíngue para todos os interessados. Tem proposta de educação bilíngue para surdos no instituto e promove a educação bilíngue nas escolas regulares brasileiras.

Uma de suas funções é contribuir para formulação da política nacional de Educação de Surdos, em adequação a Portaria MEC no $323^{14}$, de 08 de abril de 2009, e com o Decreto $\mathrm{n}^{\circ} 7.690^{15}$, de 02 de março de 2012. Por isso, promove fóruns, publicações, seminários, pesquisas e

\footnotetext{
${ }^{14}$ Portaria que provou o Regimento Interno do Instituto Nacional de Educação de Surdos.

${ }^{15}$ Decreto que aprovou a Estrutura Regimental e o Quadro Demonstrativo dos Cargos em Comissão e das Funções Gratificadas do Ministério da Educação.
} 
assessorias, além de possuir produções de material pedagógico, fonoaudiológico e vídeos em língua de sinais, que são distribuídos.

ASSOCIAÇÃO DE PAIS E AMIGOS DOS DEFICIENTES AUDITIVOS - APADA: Esta é uma instituição filantrópica fundada em 1969 por Miriam Rangel Rodrigues, após sua filha, na época com 02 (dois) anos, ter sido diagnosticada com Meningite, a qual a sequela foi a perda auditiva completa, ficando surda.

A instituição iniciou apenas para prestar informações as mães, pais e responsáveis que, naquela época, não tinham a quem recorrer. Hoje, também têm uma creche com modelo de educação inclusiva com 73 (setenta e três) crianças de 04 (quatro) meses a 06 (seis) anos, com horário de entrada às 08 (oito) horas e saída às 17 (dezessete) horas. Esta creche tem um convênio com o Programa Criança na Creche da Prefeitura de Niterói.

Um dos principais objetivos é que enquanto crianças sejam preparados para serem adultos capazes de lutar pelo direito de exercício de sua cidadania.

Para mais, mantém uma parte clínica com atendimentos em fonoaudiologia, ludoterapia, psicomotricidade e terapia psicológica para adolescentes e adultos surdos. Além de um Centro Avançado de Diagnóstico Audiológico, com exames de Audiometria e Impedanciometria em todos os procedimentos. Processamento Auditivo Central, Vectoeletronistagmografia, Bera-peate, Reabilitação Vestibular e Videolaringnoscopia. Exames feitos pelo SUS ou particulares além de convênio com a CASSI (Caixa de Assistência dos Funcionários do Banco do Brasil).

Oferecem cursos de Libras para familiares e comunidade em geral com preços módicos, que contam com professores surdos.

FEDERAÇÃO NACIONAL DE EDUCAÇÃO E INTEGRAÇÃO DE SURDOS - FENEIS: Uma instituição sem fins lucrativos, que visa a defesa de políticas educacionais, culturais, de saúde e assistência social, em 
favor da comunidade surda do Brasil, na luta e defesa de seus direitos. É filiada à Federação Mundial dos Surdos, numa rede de seis Administrações Regionais, as quais foram reconhecidas como de utilidade pública federal, estadual e municipal.

Com o intuito de valorizar o ser humano, estimular sua autonomia pessoal, interação e contato com a diversidade de pensar, agir e sentir, oferece atividades de turismo social, programas de saúde e educação ambiental, além de contar com programas especiais para crianças e idosos.

Por acreditar que a educação é pressuposto para a transformação social, uma de suas principais defesas é o reconhecimento da cultura surda, por meio da difusão Libras, especialmente através de sua inserção no mercado de trabalho, dos trabalhadores surdos em cargos de maior destaque junto à sociedade, evidenciando suas competências profissionais.

São atendidos pela Feneis: surdos, pessoas com perda auditiva, professores de Libras, pesquisadores, familiares de surdos, instituições, organizações governamentais e não-governamentais, profissionais da área, entre outras.

INSTITUTO MUNICIPAL HELENA ANTIPOFF - IAH: Este instituto integra a Secretaria Municipal de Educação (SME) e é responsável pela implementação das Políticas Públicas da Educação Especial, conforme diretrizes do MEC/SECADI, com a perspectiva inclusiva. Promove ações que não são voltadas apenas para surdos, mas também para alunos com os mais diversos tipo de limitações, transtornos globais do desenvolvimento e altas habilidades/superdotação nas escolas da Rede Pública Municipal.

O método adotado é o da inclusão, assim, um aluno surdo é colocado em uma turma de ouvintes. Não há a determinação de existência de classes de alunos que apresentam esta mesma característica, embora haja recomendação de que alunos surdos sejam agrupados em maior número na mesma classe para que haja comunicação por meio da Libras e a presença de um intérprete ou instrutor. 
Estas classes devem ser revistas periodicamente pelo Atendimento Educacional Especializado (AEE), para aferir a integração do aluno com a turma.

Desta forma, busca garantir o uso da Libras para os alunos surdos, para a comunidade escolar e, quando possível, para seus familiares, inclusive por meio de programa de formação de usuários da língua brasileira de sinais.

Requer ainda a ampliação das escolas bilíngues (português-Libras), contratação de intérpretes e instrutores de Libras para salas de recursos e oferecimento de curso de Libras aos professores.

O Instituto ainda atua organizando e encaminhando os educadores empenhados na educação de surdos e conta com Equipe de Acompanhamento que avaliará, juntamente com a Assessoria de Ação Integradora e da Gerência de Educação da Coordenadoria Regional de Educação (CRE), caso haja necessidade de incluir mais alunos com deficiência nas classes. 


\section{DO DIREITO À EDUCAÇÃO}

"Há ainda aqueles outros ouvintes que fazem 'caridade'. Abrem espaço para os surdos, mas não incentivam os surdos a pensar, pois continuam sendo o centro, os fazedores de tudo".

(Autor desconhecido; CHOI, et al., 2011)

A Constituição Federal, em seu artigo 208, inciso I, diz que educação básica é obrigatória e gratuita dos 04 (quatro) aos 17 (dezessete) anos de idade, garantindo inclusive acesso gratuito para todos os que, por quaisquer circunstâncias, não tiveram acesso a ela na idade própria (Brasil, 1988).

A educação básica constitui-se de três ciclos de ensino: educação infantil, ensino fundamental e ensino médio. A educação infantil é a primeira etapa e "tem como finalidade o desenvolvimento integral da criança de até 5 (cinco) anos, em seus aspectos físico, psicológico, intelectual e social, complementando a ação da família e da comunidade" (Brasil, Lei $\mathrm{n}^{\circ}$. 9.394, de 20 de dezembro 1996, art. 29). O ensino fundamental inicia aos 06 (seis) anos de idade e tem duração de 09 (nove) anos e, conforme incisos do artigo 32, da Lei de Diretrizes e Bases da Educação Nacional, deve culminar na formação básica do cidadão, mediante:

\footnotetext{
"I - o desenvolvimento da capacidade de aprender, tendo como meios básicos o pleno domínio da leitura, da escrita e do cálculo;

II - a compreensão do ambiente natural e social, do sistema político, da tecnologia, das artes e dos valores em que se fundamenta a sociedade;

III - o desenvolvimento da capacidade de aprendizagem, tendo em vista a aquisição de conhecimentos e habilidades e a formação de atitudes e valores;

IV - o fortalecimento dos vínculos de família, dos laços de solidariedade humana e de tolerância recíproca em que se assenta a vida social." (Brasil, Lei no . 9.394, de 20 de dezembro 1996)
}

E o ensino médio, que é a etapa final da educação básica, tem por finalidade o disposto nos incisos do artigo 35 da Lei de Diretrizes e Bases da Educação Nacional, o qual aduz: 
"I - a consolidação e o aprofundamento dos conhecimentos adquiridos no ensino fundamental, possibilitando o prosseguimento de estudos;

II - a preparação básica para o trabalho e a cidadania do educando, para continuar aprendendo, de modo a ser capaz de se adaptar com flexibilidade a novas condições de ocupação ou aperfeiçoamento posteriores;

III - o aprimoramento do educando como pessoa humana, incluindo a formação ética e o desenvolvimento da autonomia intelectual e do pensamento crítico; IV - a compreensão dos fundamentos científico-tecnológicos dos processos produtivos, relacionando a teoria com a prática, no ensino de cada disciplina." (Brasil, Lei no . 9.394, de 20 de dezembro 1996)

Logo, a grande finalidade da educação no momento da infância e adolescência é moldar o adulto em perspectiva, de forma a prepará-lo para as demandas do convívio social. O artigo 205 da CRFB/88 diz o seguinte:

“Art. 205. A educação, direito de todos e dever do Estado e da família, será promovida e incentivada com a colaboração da sociedade, visando ao pleno desenvolvimento da pessoa, seu preparo para o exercício da cidadania e sua qualificação para o trabalho.” (Brasil, 1988)

Aí estão descritos os objetivos da educação: "pleno desenvolvimento da pessoa", "preparo para o exercício da cidadania", "qualificação para o trabalho"; sendo assim, a instituição de ensino deve proporcionar um sistema educacional que gere efeitos nestes três aspectos do indivíduo. Por isso, podemos afirmar que é um autêntico direito social de cidadania, não se pode exercer a cidadania sem educação ao passo que a educação faz parte do processo de cidadania. Neste sentido é que afirma Francisco Dias que "a educação tem duas dimensões na sua relação com a cidadania: é um direito da cidadania, mas também uma exigência imperativa para o seu exercício pleno.” (Koerner et al., 2005, p. 239)

Mas para se atingir estes objetivos é preciso inicialmente compreender que o meio pelo qual se tentará alcançar estes objetivos é muito importante, deve haver um conjunto de normas pedagógicas capazes de propiciar ao indivíduo desenvolvimento, nos seus diversos aspectos, cultural, humanístico, intelectual, dentre outros aspectos gerais internos e externos.

Assim, garantir o direito à educação não tem a ver unicamente com um aspecto formal de universalização do acesso ao ambiente escolar, 
inclusive tornando obrigatória a prestação de ensino público dos 04 (quatro)

aos 17 (dezessete) anos de idade, ou com a inauguração de mais escolas de educação básica, diz respeito a construção de um ambiente que corresponda ao direito de ser educado inerente a todo aluno. Este deve ser o pilar da instituição educacional (vale dizer mais uma vez): o direito de ser educado todo aluno matriculado na instituição. Conforme esclarece muito bem Francisco Dias, nos seguintes termos:

\begin{abstract}
"Pode-se garantir o direito à educação universalizando a fase do ensino obrigatório e público, de forma que nenhuma criança esteja fora das escolas, ao menos nas estatísticas das matrículas, e assim garanto o direito à educação restringindo-o à educação escolar. Mas isso não quer dizer que se estará garantindo o direito a ser educado usufruindo de tudo o que já se conseguiu construir como dignidade humana. Esse direito se realiza como um conjunto de condições e ações sociais que permitem a toda criança e adolescente vivenciar as múltiplas dimensões da pessoa, por meio das experiências societárias e individuais que compõem a herança cultural da humanidade e da sociedade em que vivem. Isso inclui valores que tornam possível o desenvolvimento pessoal numa convivência pacífica apoiada na igualdade e na liberdade, sem as quais não é possível falarmos em democracia ou justiça.” (Ibid., 2005, p. 239)
\end{abstract}

Assim, compreendemos que a educação é também uma experiência social que não está dotada da formalidade de uma estrutura escolar, que deve ser apenas parte do processo de aprendizado. Neste sentido podemos interpretar o artigo $206^{16}$ da CRFB o qual trata dos princípios basilares do ensino, com relação a pessoa do educando, da seguinte forma:

a) "igualdade de condições para o acesso e permanência na escola": a instituição de ensino deve proporcionar tratamento desigual para que haja um ambiente escolar com igualdade de condições, no qual todos os alunos poderão ingressar sem

\footnotetext{
16 “Art. 206. O ensino será ministrado com base nos seguintes princípios: I - igualdade de condições para o acesso e permanência na escola; II - liberdade de aprender, ensinar, pesquisar e divulgar o pensamento, a arte e o saber; III - pluralismo de idéias e de concepções pedagógicas, e coexistência de instituições públicas e privadas de ensino; IV - gratuidade do ensino público em estabelecimentos oficiais; V - valorização dos profissionais da educação escolar, garantidos, na forma da lei, planos de carreira, com ingresso exclusivamente por concurso público de provas e títulos, aos das redes públicas; VI - gestão democrática do ensino público, na forma da lei; VII garantia de padrão de qualidade. VIII - piso salarial profissional nacional para os profissionais da educação escolar pública, nos termos de lei federal.

Parágrafo único. A lei disporá sobre as categorias de trabalhadores considerados profissionais da educação básica e sobre a fixação de prazo para a elaboração ou adequação de seus planos de carreira, no âmbito da União, dos Estados, do Distrito Federal e dos Municípios.” (Brasil, 1988)
} 
impedimentos de natureza discriminatória e desenvolver suas capacidades de igual forma;

b) "liberdade de aprender, ensinar, pesquisar e divulgar o pensamento, a arte e o saber": o ambiente escolar deve favorecer ao estudante o compartilhamento de suas ideias, a expressão de sua opinião e conceitos, de maneira responsável, e aspectos culturais relacionados a ele e ao seu meio social, bem como este também deve estar apto a receber tais conhecimentos;

c) "pluralismo de ideias e de concepções pedagógicas, e coexistência de instituições públicas e privadas de ensino": a prática do ensino deve propiciar o conhecimento nas mais diversas áreas do saber, com as mais diversas maneiras de transmitir o conhecimento, fazendo saber ao aluno o mundo plural em que vive;

d) "gratuidade do ensino público em estabelecimentos oficiais": a garantia de que o Poder Público fornecerá escolas com padrões educacionais apropriados de forma gratuita para que todos possam ter acesso ao ensino;

e) "gestão democrática do ensino público, na forma da lei”: o compromisso em desenvolver um ambiente de aprendizado no qual há espaço para a participação da comunidade escolar, além de a gestão demonstrar-se íntegra e comprometida com os interesses sociais, e acrescenta Helena Singer: "esta é a concepção básica dos educadores envolvidos com as escolas democráticas: respeito à criança como um ser humano já completo e, portanto dignitário de todos os seus direitos." (Ibid., 2005, p. 184);

f) "garantia de padrão de qualidade ${ }^{17 "}$ : o dever de prover ensino de acordo com o que se estabeleceu de conteúdo essencial para

\footnotetext{
${ }^{17}$ A crítica de Anísio Teixeira vai ainda além da exigência de um padrão de qualidade - mesmo que suas declarações tenham sido escritas há anos atrás ainda nos parecem bem atuais - nos chama atenção aos problemas do modelo educacional atual que seria um "formador de elites" garantindo a perpetuação do sistema de desigualdade social, ao invés de superá-lo. São suas palavras: "Esta é, exatamente, a fase que estamos a viver na educação nacional. Expandimos o sistema, ampliamos o número das escolas, mas não cuidamos de sua seriedade nem de sua eficiência, pois o seu fim não é educar o povo mas selecionar um número maior de candidatos à única educação que conta em
} 
aquela fase da vida do aluno, não se admitindo menos que isso para que não hajam privilégios com relação ao conhecimento, mas que haja qualidade em todos os segmentos.

O que estamos falando é de um direito que vai além de condições materiais para sua efetivação. A educação é um direito sublime, por sua própria natureza, inegavelmente fundamental, pois é por meio do exercício deste que o indivíduo pode desenvolver suas demais capacidades, seu intelecto, suas convicções, o lidar com o outro, sua cultura. É o meio pelo qual o indivíduo se descobre infinito em suas potencialidades, conforme bem ilustra Francisco Dias introduzindo o conceito do que chama de "educabilidade":

\begin{abstract}
"Dessa forma, para continuar a reflexão sobre o direito a ser educado, farei uso do conceito de educabilidade, que nos permite uma aproximação com aspectos da realidade que podem não ser apreendidos se o nosso horizonte teórico restringirse ao direito à educação. Tal conceito parte das premissas de que todo homem é potencialmente educável e de que tal potencialidade ontologicamente se realiza no existir e suas circunstâncias. Dessas circunstâncias dependerá a educabilidade, o que significa também que delas dependerá o que será educado. Assim, ela está referida às condições materiais de existência, aos recursos culturais e às atitudes socialmente compartilhadas que condicionam o indivíduo no seu fazer como pessoa humana. Tais condições tanto podem otimizar a educabilidade para uma ação educativa em direção à plenitude humana nunca alcançável - posto que potencialmente infinita -, como podem ser obstáculos intransponíveis para a sua realização. $O$ que nos leva a fazer as seguintes afirmações: a) não são todos igualmente educáveis porque não estão todos em iguais circunstâncias de existência; b) a educabilidade exige condições mínimas de eqüidade para que o fazer educativo socialmente definido para a fruição da dignidade humana, incluindo o direito à educação como direito humano fundamental, possa realizarse para todos com êxito. (Ibid., 2005, p. 240)".
\end{abstract}

Desta forma, compreende-se por educabilidade a união indissociável de condições de igualdade materiais e subjetivas para o processo social de educação - que por último passa pelo indivíduo, se iniciando pelo Estado e pela família - que a sociedade estipulou para os cidadãos, é um direito humano inerente ao direito humano à educação (Ibid., 2005, p. 240). Assim não garantir tal direito é também usurpar uma série de outros direitos

um país ainda dividido, bifurcado em elite diplomada e massa ignorante. A ampliação do sistema é uma simples ampliação quantitativa, sem a reconstrução, que se impõe, da escola e dos seus objetivos.” (1999, p. 115). O que se defende é que a educação só se torna o meio mais eficaz de combate às desigualdades, se observados todos os princípios a ela intrínsecos. 
associados a este, como acesso à cultura, cidadania e dignidade. A sua não concretização é afirmação e integralização à sociedade da ideia de que algumas pessoas não teriam direito a ter direitos, o que é completamente contraditório a própria ideia de direito (Ibid., 2005, p. 240, 241).

E para que todos tenham acesso à educação era mesmo fundamental que fosse imputado ao Estado promovê-lo, porquanto, assim como demais direitos sociais, caso contrário só teria acesso a este direito aquele que fosse capaz de buscá-lo no mercado, o que contribuiria apenas para o crescimento das desigualdades, uma vez que aquele que não possuísse condições de pagar pelo acesso à educação teria de se submeter à condições injustas e à opressão de sua personalidade. Como bem conclui Anísio Teixeira:

"Obrigatória, gratuita e universal, a educação só poderia ser ministrada pelo Estado. Impossível deixá-la confiada a particulares, pois estes somente podiam oferecê-la aos que tivessem posses (ou a "protegidos") e daí operar antes para perpetuar as desigualdades sociais, que para removê-las." (1999, p. 83)

A educação não deve jamais ser vista como privilégio de alguns, mas deve ser ampla e acessível a todos. Bem como não deve em tempo algum se tornar instrumento de obtenção de lucro o que seria se o Estado a deixasse sob o encargo de particulares a promoção destas. A educação tem o condão de gerar efeitos internos nos seus destinatários que influenciarão todo seu modo de viver. Vale evidenciar a contribuição de Martha Nussbaum para este entendimento:

\begin{abstract}
"A minha preocupação é que as outras habilidades, habilidades cruciais para a saúde interna de qualquer democracia, para a criação de uma cultura descente, para um modelo robusto de uma cidadania mundial e para abordar os problemas mais prementes do mundo estão em risco de se perder nessa busca competitiva por lucro. Estas habilidades estão associadas com as humanidades e as artes: são a capacidade de pensar criticamente, a capacidade de transcender lealdades locais para a abordagem de problemas mundiais assumindo a posição de um 'cidadão do mundo' e, finalmente, a capacidade de imaginar simpaticamente a situação de outra pessoa." (Nussbaum, 2009, p. 04)"
\end{abstract}

Destaque-se também o potencial de criação de cultura ${ }^{18}$ que tem a educação, pois é a partir de habilidades, costumes e valores do indivíduo

\footnotetext{
${ }^{18}$ É válido salientar aqui a proteção que a Constituição Federal oferece à cultura, não apenas às formas materiais de cultura, mas também as imateriais, conforme art. 216, da CRFB/88.
} 
que nasce um aspecto cultural, é no processo de formação do indivíduo que surgem as criações e o progresso, o que é capaz de transformar realidades. É na realização de suas capacidades que se desenvolve como pessoa, em vista disso, exerce seus direitos fundamentais.

Por fim, concluímos este tópico citando mais uma vez Martah Nussbaum que neste trecho, falando sobre o propósito da educação, resume em poucas palavras o objetivo de todo o esclarecimento acima exposto:

\begin{abstract}
"É preciso, em primeiro lugar, promover o desenvolvimento humano de seus alunos. E é preciso, em segundo lugar, promover a compreensão dos alunos de que os objetivos do desenvolvimento humano são para todos, enquanto metas inerentes à própria idéia de uma sociedade justa minimamente decente, de tal forma que quando eles forem habilitados buscarão fazer escolhas políticas que irão promover estas capacidades para todos e não só para si. Então, na minha versão, essa educação terá início a partir da idéia de igual respeito para todos os seres humanos e da igualdade de acesso de todos a uma gama de oportunidades humanas centrais, e não apenas em sua própria nação, mas em todo o mundo. Assim, minha concepção possui desde o início um profundo e igualitário componente crítico. (Acredito inclusive que minha versão é mais forte criticamente do que outras versões baseadas nas capacidades). Portanto, a educação irá promover o enriquecimento dos sentidos do aluno, da imaginação, do pensamento e da razão prática, por exemplo, e irá, igualmente, promover uma visão da humanidade, segundo a qual todos os seres humanos têm direito a esse tipo de desenvolvimento numa base de igualdade." (Ibid., 2009, p. 11, 12)
\end{abstract}

\title{
3.1. Legislação sobre a Educação de Pessoas Surdas
}

Neste tópico analisaremos de forma mais específica como se dá o direito à educação, neste entendimento, no contexto da população surda, nas legislações pertinentes a fim de demonstrar a existência de base jurídica para um modelo educacional mais efetivo do que o atualmente existente.

\subsubsection{De Âmbito Federal}

\section{CONSTITUIÇÃO DA REPÚBLICA FEDERATIVA DO BRASIL}

DE 1988: A CRFB dispõe sobre educação dos artigos 205 ao 214. Merecem destaque o inciso ${ }^{19}$ III do artigo 206 e incisos ${ }^{20}$ III e V, do artigo 208, pois

\footnotetext{
${ }^{19}$ Artigo já supracitado.
} 
apresentam os princípios de "liberdade de aprender", "pluralismo de ideias e concepções pedagógicas" 21 e "segundo a capacidade de cada um".

Liberdade podemos compreender pela esfera composta pelo conjunto de vontades que pode o indivíduo exercer, desde que não fira esta esfera do outro, assim, a liberdade de aprender pode ser compreendida pelo conjunto de vontades que facilitam o aprendizado, leia-se, as maneiras de aprendizado encontrados dentro da própria pessoa.

Associando este princípio aos demais supramencionados, está aí apresentado um modelo educacional no qual se capta do aluno o ensino que melhor lhe corresponde e não de um sistema pré-determinado, assim, dando margem ao pluralismo de ideias e concepções pedagógicas favorecendo este processo de aprendizado e se adequando a capacidade de cada um para que o ensino seja efetivo, gerando efeitos de ordem social (externa ao indivíduo) e de ordem subjetiva (interna ao indivíduo).

LEI N ${ }^{\circ}$ 7.853, DE 24 DE OUTUBRO DE 1989: A finalidade desta Lei é estabelecer normas que assegurem o pleno exercício dos direitos individuais e sociais das pessoas com deficiência, para que haja integração social destas pessoas, igualdade de tratamento e oportunidade, justiça social, respeito a dignidade da pessoa humana e seu bem-estar, dentre outros princípios constitucionais, por meio das ações governamentais necessárias para tal, visto ser obrigação nacional a cargo do Poder Público e da sociedade (Brasil, 1989, art. $1^{\circ}$ ).

$\mathrm{O}$ artigo $2^{\circ}$ nos chama mais atenção com relação a temática que abordamos. Vejamos o texto da Lei abaixo colacionado:

\footnotetext{
20 “Art. 208. O dever do Estado com a educação será efetivado mediante a garantia de: [...] III atendimento educacional especializado aos portadores de deficiência, preferencialmente na rede regular de ensino; V - acesso aos níveis mais elevados do ensino, da pesquisa e da criação artística, segundo a capacidade de cada um; [...]." (Brasil, 1988)

${ }^{21}$ Quanto a este princípio, é pertinente trazer a análise feita por Edmarcius Carvalho Novaes, conforme enunciado: "Por ser princípio elencado na Carta Magna, não se pode, nem de longe, afirmar, de forma alguma, que o modelo educacional de integração (ou inclusão, como queiram) é imperativo significando que não podem mais existir escolas especiais, no caso, para surdos. Esta afirmação vai contra um princípio defendido no texto constitucional. [...] Existe a concepção pedagógica, defendida por muitos surdos e educadores que entendem ser mais eficaz a possibilidade do modelo de individuação, ou seja, existir escolas ou classes próprias para surdos, tendo em vista sua diferença linguística e cultural." (Novaes, 2014, p. 65)
} 


\begin{abstract}
“Art. $2^{\circ}$ Ao Poder Público e seus órgãos cabe assegurar às pessoas portadoras de deficiência o pleno exercício de seus direitos básicos, inclusive dos direitos à educação, à saúde, ao trabalho, ao lazer, à previdência social, ao amparo à infância e à maternidade, e de outros que, decorrentes da Constituição e das leis, propiciem seu bem-estar pessoal, social e econômico.

Parágrafo único. Para o fim estabelecido no caput deste artigo, os órgãos e entidades da administração direta e indireta devem dispensar, no âmbito de sua competência e finalidade, aos assuntos objetos esta Lei, tratamento prioritário e adequado, tendente a viabilizar, sem prejuízo de outras, as seguintes medidas:

I - na área da educação:

a) a inclusão, no sistema educacional, da Educação Especial como modalidade educativa que abranja a educação precoce, a pré-escolar, as de $1^{\circ}$ e $2^{\circ} \operatorname{graus}^{22}$, a supletiva, a habilitação e reabilitação profissionais, com currículos, etapas e exigências de diplomação próprios;

b) a inserção, no referido sistema educacional, das escolas especiais, privadas e públicas;

c) a oferta, obrigatória e gratuita, da Educação Especial em estabelecimento público de ensino;

[...];” (Brasil, 1989)
\end{abstract}

Mais uma vez a norma legal nos dá margem a interpretação de que a pessoa surda tem assegurada a possibilidade de não apenas haverem classes especiais para surdos, mas também uma modalidade educativa própria, que podemos compreender pela inserção de materiais didáticos em Libras, educação sobre a cultura surda, e até mesmo sobre a escrita de sinais, deixando o ensino do português apenas na modalidade escrita, conforme entendimento de outra Lei que veremos mais a diante, porém sem prejuízo das demais áreas do saber.

ESTATUTO DA CRIANÇA E DO ADOLESCENTE - LEI N ${ }^{\circ}$ 8.069, DE 13 DE JULHO DE 1990: Este Estatuto tem por objetivo a proteção integral à criança e ao adolescente, assegurando que gozem de todos os direitos fundamentais inerentes à pessoa humana, além de garantir meios para seu desenvolvimento físico, mental, moral, espiritual e social, em condições de liberdade e de dignidade (arts. $1^{\circ}$ e $2^{\circ}$ ).

No que diz respeito à educação de surdos, podemos evidenciar o artigo 54, inciso III, que diz: “Art. 54. É dever do Estado assegurar à criança e ao adolescente: [...] III - atendimento educacional especializado

\footnotetext{
${ }^{22}$ Lembrando que atualmente não há mais $1^{\circ} \mathrm{e} 2^{\circ}$ graus, mas sim ensino fundamental e ensino médio.
} 
aos portadores de deficiência, preferencialmente na rede regular de ensino; [...]." (Brasil, 1990)

Há que se destacar o termo "preferencialmente" empregado pela Lei, pois demonstra que esta é uma indicação do legislador, não sendo uma ordem segui-la. No caso, alunos surdos estarem em rede de ensino regular, conforme esta Lei, seria apenas uma indicação da norma, não sendo obrigatório, mas sim uma faculdade dos pais da criança ou adolescente.

LEI DE DIRETRIZES E BASES DA EDUCAÇÃO NACIONAL LEI N ${ }^{\circ}$ 9.394, DE 20 DE DEZEMBRO DE 1996: Esta Lei disciplina a educação escolar buscando adequar o sistema educacional nacional aos princípios constitucionais basilares da educação.

Quanto à educação especial, dispõe da seguinte forma:

\footnotetext{
“Art. 58. Entende-se por educação especial, para os efeitos desta lei, a modalidade de educação escolar, oferecida preferencialmente na rede regular de ensino, para educandos portadores de necessidades especiais.

[...]

$\S 2^{\circ} \mathrm{O}$ atendimento educacional será feito em classes, escolas ou serviços especializados, sempre que, em função das condições específicas dos alunos, não for possível a sua integração nas classes comuns de ensino regular.

[...].” (Brasil, 1996)

E ainda:
}

“Art. 59. Os sistemas de ensino assegurarão aos educandos com necessidades especiais:

I - currículos, métodos, técnicas, recursos educativos e organização específicos, para atender às suas necessidades;

[...]." (Ibid., 1996)

A partir destes dois dispositivos podemos entender mais uma vez que é possível, com base legal, um ensino especializado para alunos surdos, devendo ser facultado aos responsáveis pela criança, nos termos desta lei, que o ensino seja regular ou especial, já que a Lei não obriga que seja o ensino regular, de maneira a assegurar, por meio de materiais pedagógicos próprios ao ensino de surdos, culminando em seu pleno desenvolvimento e preparo para o trabalho, como bem corresponde a justiça social. 
DECRETO N 3.298, DE 20 DE DEZEMBRO DE 1999: Esta Lei destina-se a viabilizar à pessoa com deficiência o exercício dos seus direitos individuais e sociais de forma integral e irrestrita.

Aplicado ao caso em tela, temos:

\begin{abstract}
"Art. 24. Os órgãos e as entidades da administração pública federal direta e indireta responsáveis pela educação dispensarão tratamento prioritário e adequado aos assuntos objeto deste decreto, viabilizando, sem prejuízo de outras, as seguintes medidas:

[...]

II - a inclusão, no sistema educacional, da educação especial como modalidade de educação escolar que permeia transversalmente todos os níveis e as modalidades de ensino;

[...]

$\S 1^{\circ}$ Entende-se por educação especial, para os efeitos deste decreto, a modalidade de educação escolar oferecida preferencialmente na rede regular de ensino para educandos com necessidades educacionais especiais, entre eles o portador de deficiência.

$\S 2^{\circ}$ A educação especial caracteriza-se por constituir processo flexível, dinâmico e individualizado, oferecido principalmente nos níveis de ensino considerados obrigatórios.

[...]

$\S 4^{\circ}$ A educação especial contará com equipe multiprofissional, com a adequada especialização, e adotará orientações pedagógicas individualizadas.
\end{abstract}

[...]" (Brasil, 1999)

\title{
Alinhado com o artigo 25:
}

"Art. 25. Os serviços de educação especial serão ofertados nas instituições de ensino público ou privado do sistema de educação geral, de forma transitória ou permanente, mediante programas de apoio para o aluno que está integrado no sistema regular de ensino, ou em escolas especializadas exclusivamente quando a educação das escolas comuns não puder satisfazer as necessidades educativas ou sociais do aluno ou quando necessário ao bem-estar do educando.” (Ibid., 1999)

Esta Lei viabiliza, sem prejuízo do modelo regular de ensino, o modelo ou a modalidade de educação especial como sendo outra opção de modalidade educacional. Devendo esta adequar-se ao aluno educando, portanto, se aluno surdo, a modalidade especial deve estar adequada a ele, oferecendo ensino de Libras, por exemplo, respeitando sua diferença cultural e linguística. Contando ainda com equipe multiprofissional de outras áreas da ciência para melhor orientar o ensino deste aluno. A Lei ainda dá margem a educação individualizada, com fỉm de efetivo ensino ao 
aluno, sempre com fins ao bem-estar do aluno surdo, para que ele se sinta, e tenha bases para estar, integrado a sociedade.

LEI DA LIBRAS - LEI No 10.436, DE 24 DE ABRIL DE 2002:

Esta Lei é de suma valia para compreensão da essencialidade do uso da Libras nos meios da sociedade. Foi por meio desta Lei que, finalmente, a Língua Brasileira de Sinais recebeu status de língua, reconhecendo-se seu aspecto cultural e identidade de toda uma minoria linguística brasileira, a população surda.

Faz jus a menção de alguns dos seus dispositivos:

“Art. $1^{\circ}$. É reconhecida como meio legal de comunicação e expressão a Língua Brasileira de Sinais - Libras e outros recursos de expressão a ela associados.

Parágrafo único. Entende-se como Língua Brasileira de Sinais - Libras a forma de comunicação e expressão, em que o sistema lingüístico de natureza visualmotora $^{23}$, com estrutura gramatical própria, constituem um sistema lingüístico de transmissão de idéias e fatos, oriundos de comunidades de pessoas surdas do Brasil. 24", (Brasil, 2002)

Prossegue a Lei dizendo ainda que o Poder Público em geral deve tratar da divulgação da Libras por meio de suas instituições fazendo saber que esta é a língua materna das comunidades surdas do Brasil (Ibid., 2002, art. $2^{\circ}$ ).

E ainda:

"Art. 4 . O sistema educacional federal e os sistemas educacionais estaduais, municipais e do Distrito Federal devem garantir a inclusão nos cursos de formação de Educação Especial, de Fonoaudiologia e de Magistério, em seus níveis médio e superior, do ensino da Língua Brasileira de Sinais - Libras, como

\footnotetext{
${ }^{23}$ O termo "visual-motora" foi desaprovado por muitos surdos e estudiosos do assunto, como Lucinda Ferreira que critica: "A versão final do texto de lei, apesar de aprovada, ainda apresenta muitos problemas quais sejam: [...] b) o uso de termos inapropriados, tais como 'visual-motora' , no referido parágrafo, é um exemplo do que pode ser prejudicial em um texto de lei que vai ser seguido e que deveria orientar a população. Motoras podem ser todas as línguas, já que todas são articuladas pelo ser humano, através do uso de seu próprio sistema articulatório, seja ele vocal ou gestual. O que parece que se queria dizer no texto é que a Língua Brasileira de Sinais é uma língua de modalidade espacial-visual;". (Ferreira, 2003, p. 26, 27)

${ }^{24}$ Muito nos acrescenta a problemática trazida por Lucinda Ferreira no que diz respeito a alguns termos empregados pela Lei, utilizados usualmente, porém que não correspondem a compreensão do próprio surdo de si e de sua língua. Algumas alterações sugeridas foram da expressão "meio de comunicação" por "sistema linguístico", "língua natural" por "língua materna", "deficiência auditiva" por "surdez" (Ibid., 2003, p. 23, 24); e acrescenta: "Por entendermos que a intenção era revalidar o 'status' linguístico da Língua Brasileira de Sinais, sugerimos que ela não fosse olhada apenas como meio de comunicação, mas sim como sistema linguístico a preencher todas as funções de uma língua.” (Ibid., 2003, p. 24)
} 
parte integrante dos Parâmetros Curriculares Nacionais - PCNs, conforme legislação vigente.

Parágrafo único. A Língua Brasileira de Sinais - Libras não poderá substituir a modalidade escrita da língua portuguesa." (Ibid., 2002)

É importante destacar este último também pois seu parágrafo único demonstra a natureza secundária da Língua Portuguesa aos surdos, sendo esta exigida apenas na modalidade escrita, isto significa respeito à língua materna da população surda, não os obrigando a falar como ouvintes, mas valorizando sua surdez como aspecto cultural e não como impedimento à vida social. Apresentando desta forma o bilinguismo como modelo educacional apropriado aos surdos no país.

DECRETO $\mathrm{N}^{\circ}$ 5.626, DE 22 DE DEZEMBRO DE 2005: A regulamentação da Lei da Libras favorece o reconhecimento na vida prática em sociedade a Libras como expressão cultural. Abaixo alguns dispositivos que facilitarão a compreensão do que se sustenta:

"Art. 14. As instituições federais de ensino devem garantir, obrigatoriamente, às pessoas surdas acesso à comunicação, à informação e à educação nos processos seletivos, nas atividades e nos conteúdos curriculares desenvolvidos em todos os níveis, etapas e modalidades de educação, desde a educação infantil até à superior.

$\S 1^{\circ}$ Para garantir o atendimento educacional especializado e o acesso previsto no caput, as instituições federais de ensino devem:

[...]

II - ofertar, obrigatoriamente, desde a educação infantil, o ensino da Libras e também da língua portuguesa, como segunda língua para alunos surdos;

III - prover as escolas com:

a) professor de Libras ou instrutor de Libras;

b) tradutor e intérprete de Libras-língua portuguesa;

c) professor para o ensino de língua portuguesa como segunda língua para pessoas surdas; e

d) professor regente de classe com conhecimento acerca da singularidade linguística manifestada pelos alunos surdos;

[...]

$\mathrm{V}$ - apoiar, na comunidade escolar, o uso e a difusão de Libras entre professores, alunos, funcionários, direção da escola e familiares, inclusive por meio da oferta de cursos;

VI - adotar mecanismos de avaliação coerentes com aprendizado de segunda língua, na correção das provas escritas, valorizando o aspecto semântico e reconhecendo a singularidade linguística manifestada no aspecto formal da língua portuguesa;

[...]" (Brasil, 2005) 
O disposto acima garante à pessoa surda a aceitação de sua língua materna, de sua cultura, de sua identidade. Mais do que dizer que é possível viver em sociedade sendo surdo, reconhece sua particularidade linguística como divergente a uma deficiência. Ademais, incluindo no processo de avaliação o aprendizado da Libras, de forma a constatar o efetivo aprendizado.

"Art. 15. Para complementar o currículo da base nacional comum, o ensino de Libras e o ensino da modalidade escrita da língua portuguesa, como segunda língua para alunos surdos, devem ser ministrados em uma perspectiva dialógica, funcional e instrumental, como:

I - atividades ou complementação curricular específica na educação infantil e anos iniciais do ensino fundamental; e

II - áreas de conhecimento, como disciplinas curriculares, nos anos finais do ensino fundamental, no ensino médio e na educação superior." (Ibid., 2005)

Neste entendimento, podemos conjecturar que o currículo educacional dos alunos surdos deve ser diferenciado dos alunos ouvintes, pois deve conter o ensino da Libras como primeira língua e o ensino de língua portuguesa, na forma escrita, como segunda língua, inclusive possibilitando a transferência de conhecimentos gerais do ensino das demais áreas do saber a que corresponde o aluno, por meio da língua de sinais.

“Art. 16. A modalidade oral da língua portuguesa, na educação básica, deve ser ofertada aos alunos surdos ou com deficiência auditiva, preferencialmente em turno distinto ao da escolarização, por meio de ações integradas entre as áreas da saúde e da educação, resguardado o direito de opção da família ou do próprio aluno por essa modalidade.

Parágrafo único. A definição de espaço para o desenvolvimento da modalidade oral da língua portuguesa e a definição dos profissionais de fonoaudiologia para atuação com alunos da educação básica são de competência dos órgãos que possuam estas atribuições nas unidades federadas." (Ibid., 2005)

Leia-se, a modalidade oral da língua portuguesa poderá ser ofertada, porém, faculta-se à família a inclusão do aluno surdo nesta modalidade do ensino da língua portuguesa, não é um imperativo legal, visto reconhecer-se a Libras como língua materna das pessoas surdas.

CONVENÇÃO SOBRE OS DIREITOS DAS PESSOAS COM DEFICIÊNCIA - (promulgado por: DECRETO N ${ }^{\circ}$ 6.949, DE 25 DE 
AGOSTO DE 2009): o objetivo desta convenção foi o reconhecimento da pessoa com deficiência como sujeito detentor de direitos como qualquer pessoa.

Sobre o tema, podemos apresentar o seguinte artigo:

"Artigo 24 - Educação

1) Os Estados-Partes reconhecem o direito das pessoas com deficiência à educação. Para efetivar esse direito sem discriminação e com base na igualdade de oportunidades, os Estados-Partes assegurarão sistema educacional inclusivo em todos os níveis, bem como o aprendizado ao longo de toda a vida, com os seguintes objetivos:

a) o pleno desenvolvimento do potencial humano e do senso de dignidade e autoestima, além do fortalecimento do respeito pelos direitos humanos, pelas liberdades fundamentais e pela diversidade humana;

b) o máximo desenvolvimento possível da personalidade e dos talentos e da criatividade das pessoas com deficiência, assim como de suas habilidades físicas e intelectuais;

[...]

2) Para a realização desse direito, os Estados-Partes assegurarão que:

a) as pessoas com deficiência não sejam excluídas do sistema educacional geral sob alegação de deficiência e que as crianças com deficiência não sejam excluídas do ensino primário gratuito e compulsório ou do ensino secundário, sob alegação de deficiência;

b) as pessoas com deficiência possam ter acesso ao ensino primário inclusivo, de qualidade e gratuito, e ao ensino secundário, em igualdade de condições com as demais pessoas na comunidade em que vivem;

c) adaptações razoáveis de acordo com as necessidades individuais sejam providenciadas;

[...]

e) medidas de apoio individualizadas e efetivas sejam adotadas em ambientes que maximizem o desenvolvimento acadêmico e social, de acordo com a meta de inclusão plena.

3) Os Estados-Partes assegurarão às pessoas com deficiência a possibilidade de adquirir as competências práticas e sociais necessárias de modo a facilitar às pessoas com deficiência sua plena e igual participação no sistema de ensino e na vida em comunidade. Para tanto, os Estados-Partes tomarão medidas apropriadas, incluindo:

[...]

b) facilitação do aprendizado da língua de sinais e promoção da identidade linguística da comunidade surda;

[...]" (Brasil, 2009)

Segundo este entendimento, a educação deve ser ministrada de forma a garantir o pleno desenvolvimento do potencial do aluno e sua dignidade, além de acrescentar a autoestima como um dos aspectos essenciais a dignidade humana.

Sendo assim, assegura ao surdo acesso e permanência ao ensino, não podendo ser retirado por alegação da instituição de não ser capaz de atender 
às suas necessidades, mas a instituição de ensino que deve se preocupar em oferecer o método educacional mais efetivo a ele, se adaptando às suas necessidades, englobando o ensino da Libras e promovendo a cultura surda.

PLANO NACIONAL DE EDUCAÇÃO - LEI No 13.005, DE 25 DE JUNHO DE 2014: Esta Lei dispõe direitos e objetivos de aprendizagem e desenvolvimento, para isso, estabelece metas a serem alcançadas pelo Poder Público. Há que se enfatizar a meta 4, a qual diz:

\footnotetext{
"Meta 4: universalizar, para a população de 4 (quatro) a 17 (dezessete) anos com deficiência, transtornos globais do desenvolvimento e altas habilidades ou superdotação, o acesso à educação básica e ao atendimento educacional especializado, preferencialmente na rede regular de ensino, com a garantia de sistema educacional inclusivo, de salas de recursos multifuncionais, classes, escolas ou serviços especializados, públicos ou conveniados.

Estratégias:

[...]

4.7) garantir a oferta de educação bilíngue, em Língua Brasileira de Sinais LIBRAS como primeira língua e na modalidade escrita da Língua Portuguesa como segunda língua, aos (às) alunos (as) surdos e com deficiência auditiva de 0 (zero) a 17 (dezessete) anos, em escolas e classes bilíngues e em escolas inclusivas, nos termos do art. 22 do Decreto no 5.626, de 22 de dezembro de 2005, e dos arts. 24 e 30 da Convenção sobre os Direitos das Pessoas com Deficiência, bem como a adoção do Sistema Braille de leitura para cegos e surdos-cegos;

[...]" (Brasil, 2014)
}

Aqui notadamente adotou-se como modelo ideal de educação de surdos o bilinguismo. Importantíssimo, pois reconhece a necessidade da criança surda de adquirir a Libras como língua materna, caso contrário, ela não terá identidade com nenhuma língua e é imprescindível ao seu desenvolvimento que tenha língua materna.

ESTATUTO DA PESSOA COM DEFICIÊNCIA - LEI No 13.146, DE 6 DE JULHO DE 2015: Este Estatuto é a mais nova Lei de âmbito federal, em vigor desde janeiro deste ano, tem escopo na promoção de condições de igualdade no exercício de direitos da pessoa com deficiência, de forma que esta esteja incluída à sociedade e à cidadania (Brasil, 2015, art. $1^{\circ}$, caput). Desta forma, exige que o Estado de forma alguma negligencie os meios que garantam tais direitos, conforme exemplificação do artigo que se segue: 
“Art. 28. Incumbe ao poder público assegurar, criar, desenvolver, implementar, incentivar, acompanhar e avaliar:

$[\ldots]$

III - projeto pedagógico que institucionalize o atendimento educacional especializado, assim como os demais serviços e adaptações razoáveis, para atender às características dos estudantes com deficiência e garantir o seu pleno acesso ao currículo em condições de igualdade, promovendo a conquista e o exercício de sua autonomia;

IV - oferta de educação bilíngue, em Libras como primeira língua e na modalidade escrita da língua portuguesa como segunda língua, em escolas e classes bilíngues e em escolas inclusivas;

$\mathrm{V}$ - adoção de medidas individualizadas e coletivas em ambientes que maximizem o desenvolvimento acadêmico e social dos estudantes com deficiência, favorecendo o acesso, a permanência, a participação e a aprendizagem em instituições de ensino;

$[\ldots]$

XII - oferta de ensino da Libras, do Sistema Braille e de uso de recursos de tecnologia assistiva, de forma a ampliar habilidades funcionais dos estudantes, promovendo sua autonomia e participação;"

Por conseguinte, é imperativo ao Poder Público a instituição de meios pedagógicos especializados à atenção dos estudantes surdos de forma a potencializar e incentivar suas capacidades, estimulando sua autonomia. Isto por meio da oferta de educação bilíngue, já reconhecida em Lei anterior e aqui ratificada, como modalidade de ensino e aprendizagem mais eficiente ao aluno surdo.

\subsubsection{De Âmbito Estadual}

CONSTITUIÇÃO ESTADUAL DO ESTADO DO RIO DE JANEIRO DE 1989: Esta Constituição, dentro do espaço territorial do estado do Rio de Janeiro é o vértice da pirâmide, sendo certo que todas as demais Leis de âmbito estadual devem estar em conformidade com esta, a qual deve estar em conformidade com a Constituição Federal. Logo, é de suma importância estadual o que se dispõe em seu texto.

E para nosso tema, já no artigo $8^{\circ}$ desta Constituição assenta em seu caput que "todos têm o direito de viver com dignidade", e prossegue no parágrafo único dizendo que "é dever do Estado garantir a todos uma qualidade de vida compatível com a dignidade da pessoa humana, 
assegurando a educação, $[. .$.$] ". Isto quer dizer que o estado reconhece que a$ educação é pilar da dignidade humana, e por isso o estado deve garantir acesso a tal direito de forma que resulte em vida digna ao destinatário da educação prestada.

Há que se destacar também o artigo 308, no qual se estabelece que:

“Art. 308. O dever do Estado e dos Municípios com a educação será efetivado mediante garantia de: [...] IV - atendimento educacional especializado aos portadores de deficiência e ensino profissionalizante na rede regular de ensino, quando necessário, por professores de educação especial; [...]”. (Rio de Janeiro, Estado, 1989)

Entende-se com isto que o estado reconhece que a efetividade da educação se dá mediante atendimento educacional especializado aos surdos, no caso, até mesmo com professores especialmente preparados para esta função, em caso de necessidade.

LEI Nº. 4528, DE 28 DE MARÇO DE 2005: Esta Lei tem a mesma finalidade da Lei de Diretrizes e Bases da Educação Nacional, requer, dentro da esfera estatal, assegurar o cumprimento do dever do Estado com a educação de sua população (art. $2^{\circ}$ ). Devemos salientar alguns artigos que tratam sobre o sistema de educação inclusiva:

"Art. 44 - Em conformidade com os dispositivos Constitucionais e com a Lei de Diretrizes e Bases da Educação Nacional no 9394/96 entende-se por educação inclusiva, para os efeitos desta Lei, o processo interativo de educação escolar que visa à integração social dos educandos com necessidades especiais e ou com deficiência, mediante a utilização de recursos pedagógicos e tecnológicos específicos na escola regular;

$\S 1^{\circ}$ - O Poder Público disponibilizará serviços de apoio especializado, fixo ou volante, para a escola regular, atendendo as peculiaridades de educandos com necessidades especiais e com deficiência

$\S 2^{\circ}-\mathrm{O}$ atendimento educacional será feito em classes, escolas ou serviços especializados, quando, em função de condições específicas dos alunos, não for possível sua integração nas classes comuns de ensino regular;

$\S 3^{\circ}$ - A oferta da educação especial é dever constitucional do Estado, tendo início na faixa etária de zero a seis anos e prolongando-se por todos os níveis e modalidades de educação escolar, compreendendo todos os componentes curriculares, inclusive educação física caso o aluno apresente condições para tal." (Rio de Janeiro, Estado, Lei $\mathrm{n}^{\circ}$. 4528, de 28 de março de 2005)

Note-se que o dispositivo legal diz que o modelo de educação inclusiva é aquele que atende aos alunos com necessidades especiais em 
escola regular, porém com material didático próprio, no entanto nos parágrafos deste artigo abre-se margem ao ensino especializado, podendo ocorrer em classes, escolas ou serviços especializados em razão das condições específicas do aluno. Aplicando isto à matéria de estudo, podemos afirmar que o texto legal viabiliza que alunos surdos tenham ensino especializado em classes, escolas ou serviço especializado, sendo dever constitucional do Poder Público proporcionar a este aluno o conteúdo correspondente aos demais de sua faixa etária, porém com utilização de materiais didáticos e recursos que facilitem sua compreensão.

Prossegue no artigo 45:

“Art. 45. O Poder Público assegurará:

I - espaços acessíveis e adequados, currículos próprios, métodos, técnicas e recursos pedagógicos e tecnológicos para atender às necessidades dos educandos com deficiência.;

II - professores com especialização adequada em nível médio ou superior, para atendimento especializado, bem como formação continuada a professores do ensino regular, visando à inclusão dos educandos com necessidades especiais nas classes comuns e a sua real aprendizagem;

[...]

IV - educação especial para o trabalho, visando à efetiva integração do educando na vida em sociedade, inclusive para os que não revelarem condições de inserção no trabalho competitivo, mediante articulação com órgãos oficiais afins, bem como para aqueles que apresentem habilidade superior nas áreas artística, intelectual e psicomotora;

$[\ldots]$

IX - turmas para ensino da Língua Brasileira de Sinais - LIBRAS - de forma a facilitar a comunicação entre os alunos integrados às turmas regulares, entre alunos e professores e entre os portadores de deficiência auditiva e seus responsáveis." (Ibid., 2005)

A expressão "currículos próprios", além de materiais e métodos, nos dá margem a compreensão pela possibilidade de inclusão de materiais didáticos e aulas que compreendam a cultura surda, esclarecendo ao aluno surdo aspectos de sua identidade cultural.

Professores capacitados para o ensino especializado e educação visando o preparo do aluno surdo para o trabalho são outros objetivos que trazem esta Lei, significativos, pois garantem a este aluno a efetiva educação que favorece sua vida em sociedade e exercício da cidadania, além de que turmas próprias para o ensino de Libras propiciam ao aluno 
surdo um ambiente mais confortável, onde ele pode externar pensamentos de melhor forma e também cria um ambiente de confiança onde o aluno sente-se respeitado em sua diferença linguística, revela-o uma nova perspectiva de que o mundo quer sim se comunicar com ele.

PLANO ESTADUAL DE EDUCAÇÃO - (instituído por: LEI N ${ }^{\circ}$ 5597 DE 18 DE DEZEMBRO DE 2009): Os objetivos deste Plano com relação a educação básica são os de ampliar e universalizar o ensino com qualidade para que aqueles que desejem cursar o ensino superior tenham base para tal e para que o educando esteja apto a ingressar no mercado de trabalho em igual condições aos demais.

Foi um grande avanço deste Plano e diferencial com relação ao Plano Municipal, estabelecer a seguinte meta:

\begin{abstract}
"Garantir, a partir da publicação deste Plano, a acessibilidade ao currículo do ensino regular aos alunos surdos com domínio da Língua Brasileira de Sinais LIBRAS, por meio de professores bilíngües em Língua Portuguesa na modalidade escrita/Libras, da Educação Infantil até os anos iniciais do Ensino Fundamental, e Tradutor/Intérprete de Libras nos anos finais do Ensino Fundamental e no Ensino Médio.” (Rio de Janeiro, Município, 2009, meta 19)

Esta meta, sendo aplicada, garante ao aluno o direito de se comunicar, receber informações e se expressar em sua língua materna, facilitando a compreensão do conteúdo ensinado, colaborando para seu desenvolvimento intelectual. Além do mais, respeita a Lei de Libras no que diz respeito à língua portuguesa, sendo exigível ao surdo apenas na modalidade escrita, reconhecendo sua diferença linguística e não a
\end{abstract} reprimindo ${ }^{25}$.

\title{
3.1.3. De Âmbito Municipal
}

\section{LEI ORGÂNICA DO MUNICÍPIO DO RIO DE JANEIRO DE} 1990: A Lei Orgânica é a Lei Maior de um município, por isso é de grande

\footnotetext{
${ }^{25}$ Há também que se parabenizar a comissão que elaborou o Plano Estadual de Educação do Rio de Janeiro pelo emprego correto do termo "surdos" e não demais terminologias ofensivas, comumente utilizadas. E pela valorização da Língua de Sinais, reconhecendo seu caráter essencial na comunicação de surdos entre si e com ouvintes.
} 
relevância o que nela for disposto. No capítulo II, que trata dos Direitos Fundamentais, diz no artigo $12^{26}$ que o município deve assegurar o direito à educação com absoluta prioridade e está ao lado do direito à dignidade em razão da essencialidade da manutenção destes direitos. E ainda o caput do artigo 13 traz uma importante declaração a respeito do direito à educação:

“Art. 13. O Município buscará assegurar às pessoas portadoras de qualquer deficiência a plena inserção na vida econômica e social e o total desenvolvimento de suas potencialidades, assegurando a todos uma qualidade de vida compatível com a dignidade humana, a educação especializada, serviços de saúde, trabalho, esporte e lazer." (Rio de Janeiro, Município, Lei Orgânica, 1990)

Nisto o município se compromete a zelar pelo desenvolvimento da pessoa surda, providenciando os aparatos necessários à ampliação e aperfeiçoamento de suas potencialidades, inclusive por meio de ensino especializado.

Porém, é no capítulo que trata do desenvolvimento social que haverá uma seção que aborda de maneira específica sobre a educação, dos artigos 320 ao 336. Assim como na Constituição Federal, fala sobre a educação ser direito de todos e dever do Estado e da família, e traz os mesmos princípios, acrescentando apenas alíneas com relação ao padrão de qualidade.

Aproveita evidenciar o artigo 322, inciso VI, abaixo colacionado:

“Art. 322 - O dever do Município será efetivado assegurando:

[...]

VII - o atendimento educacional especializado aos portadores de deficiência por equipe multidisciplinar de educação especial, mediante:

a) matrícula em escola de rede municipal mais próxima de sua residência, em turmas comuns, ou, quando especiais, segundo critérios determinados para cada tipo de deficiência;

b) integração, sempre que possível, nas atividades comuns da escola;

c) oferta de equipamento, recursos humanos e materiais nas escolas municipais, adequando-os, sempre, ao tipo de deficiência;" (Ibid., art. 322)

À luz deste artigo podemos concluir que embora não seja prioridade o ensino especializado para surdos, visto que prioriza o ingresso destes

\footnotetext{
26 “Art. 12. O Município buscará assegurar à criança, ao adolescente e ao idoso, com absoluta prioridade, o direito à vida, à moradia, à saúde, à alimentação, à educação, à dignidade, ao respeito, à liberdade, à convivência familiar e comunitária e à primazia no recebimento de proteção e socorro, além de colocá-los a salvo de toda forma de negligência, discriminação, exploração, violência, crueldade e opressão." (Rio de Janeiro, Município, Lei Orgânica, 1990, art. 12)
} 
alunos em classes comuns, há esta possibilidade, inclusive com uma classe especialmente para alunos surdos, é a margem que este artigo dá. Devendo ainda contar com equipe multidisciplinar, que, normalmente, voltado a surdez, se constitui principalmente de fonoaudiólogos e pedagogos. E quanto aos materiais adequados, podemos incluir aí materiais que expressem a cultura surda, pois o aluno precisa se sentir representado e saber que há produção cultural em sua língua materna.

LEI N 1.756, DE 03 DE SETEMBRO DE 1991: Esta lei é de grande avanço, porquanto oferece um modelo educacional cuja efetividade do ensino é prioridade, o qual, nos deparando com as escolas municipais que temos atualmente, percebemos que até hoje não foi de fato implementado ${ }^{27}$. Logo no artigo $1^{\circ}$, determina da seguinte forma:

\footnotetext{
“Art. $1^{\circ}$ - $\mathrm{O}$ atendimento educacional na rede municipal de ensino público aos alunos portadores de deficiência será ministrado mediante:

I - criação de unidades escolares ou sala de recursos para grupos especiais formados por educandos com a mesma deficiência;

II - orientação de equipe multidisciplinar especializada no ensino a deficientes;

III - prévia avaliação, pela equipe multidisciplinar, das necessidades, ou não, da inclusão do educando em grupos especiais.

$\S 1^{\circ}$ - Na hipótese de o atendimento ser prestado em grupo especial, este será composto, no máximo, de dez alunos.

$\S 2^{\circ}$ - Todos os Distritos de Educação do Município possuirão equipe multidisciplinar especializada no atendimento a deficientes.

$\S 3^{\circ}$ - Os alunos, quando possível, serão preparados para o seu ingresso em turmas regulares.

$\S 4^{\circ}$ - Os Distritos de Educação do Município deverão dispor de, pelo menos, uma sala de recursos." (Id., Lei n ${ }^{\circ}$. 1.756, de 03 de setembro de 1991, art. $1^{\circ}$ )
}

Este artigo dá base para a criação de unidades escolares públicas municipais ou classes em unidades escolares públicas municipais voltadas apenas para surdos, apenas se e quando possível estes alunos seriam incluídos em turmas regulares, ademais as classes especializadas devem ter aulas sendo ministradas por professores surdos. A qual poderia ser mais eficaz tendo em vista a particularidade linguística e cultural das pessoas surdas.

\footnotetext{
${ }^{27}$ Ocorre que até o presente momento não houve regulamentação desta Lei seguindo determinação do artigo $8^{\circ}$ desta.
} 
Bem como uma equipe multidisciplinas especializada que podemos compreender pela presença profissionais intérpretes, fonoaudiólogos e pedagogos, além dos professores para que avaliem a necessidade ou não do aluno de ser incluído em turma especializada, cuja equipe deve constar em todos os Distritos de Educação do Município para que as mais diversas regiões municipais possam ter acesso a esta equipe especializada, preparada para atender alunos surdos, e uma sala de recursos, os quais podemos concluir como sendo materiais didáticos próprios à educação de surdos, tais como poesia da literatura surda, história dos surdos, dicionário da Libras, dentre outras produções da cultura surda, também conforme art. $6^{0^{28}}$ da mesma Lei.

Do mesmo modo, as turmas devem ser pequenas para que o educador possa dar a devida atenção para seus alunos. E o educador que conduzir o ensino especializado oferecerá atendimento extraclasse ${ }^{29}$ para os alunos surdos que integrarem turma regular.

Esta Lei ainda ressalta a importância do Instituto Helena Antipoff ${ }^{30}$ cuja função seria prestar orientações aos educadores. Senão, instituição semelhante.

LEI No 2.401, DE 9 DE ABRIL DE 1996: esta é a Lei que reconhece a Libras como língua no plano municipal. Porém há críticas a se fazer quanto a disposição do artigo $1^{\circ}$, que diz: "Fica o Poder Executivo autorizado a reconhecer oficialmente no Município a linguagem gestual codificada na Língua Brasileira de Sinais-Libras e outros recursos de expressão a ela associados como meio de comunicação objetiva e uso corrente.". Foram muito mal empregados os termos "linguagem gestual",

\footnotetext{
28 “Art. $6^{\circ}$ - As escolas especiais e as salas de recursos serão supridas de equipamentos, materiais e instrumentos necessários aos atendimentos aos alunos portadores de deficiência." (Rio de Janeiro, Município, Lei $n^{\circ} 1.756$, de 03 de setembro de 1991, art. $6^{\circ}$ )

29 “Art. $4^{\circ}$ - O aluno portador de deficiência, já incluído em turma regular, terá atendimento específico extraclasse, pelo professor do Distrito de Educação que estiver trabalhando com o grupo com a mesma deficiência, na escola em que for matriculado, ou onde estiver funcionando o grupo." (Ibid., art. $4^{\circ}$ )

30 "Art. $3^{\circ}$ - Os profissionais integrantes da equipe multidisciplinar a que se refere esta Lei receberão orientação técnica do Instituto Helena Antipoff, ou de entidade similar a ser criada." (Ibid., art. $3^{\circ}$ )
} 
porquanto, a Libras tem toda uma estrutura gramatical própria de uma língua, inclusive já reconhecido como tal, portanto a utilização deste termo é errônea, bem como "gestual", pois a Libras não é composta por gestos, mas por sinais compostos por cinco aspectos: configuração das mãos, localização, movimento, orientação das palmas das mãos e traços não manuais. Libras é uma língua de expressão cultural de uma minoria linguística surda.

PLANO MUNICIPAL DE EDUCAÇÃO - (aprovado pela LEI N . 4.866 DE 02 DE JULHO DE 2008): A finalidade deste Plano é estabelecer um planejamento na forma de metas e objetivos para num prazo de 10 (dez) anos alcançar uma melhora significativa na qualidade do ensino das escolas da cidade do Rio de Janeiro. Merecem destaque ao menos dois pontos deste plano de metas, os quais: "assegurar a partir da aprovação deste Plano, que crianças portadoras de necessidades educacionais especiais sejam atendidas na rede regular de Creches e Pré-escolas, garantindo suas necessidades e o direito de atendimento especializado;" e "garantir o acesso e a permanência, com sucesso, de todas as crianças na escola, estabelecendo, em regiões em que se demonstrar necessário, programas específicos, com a colaboração da União e do Estado.”. O primeiro ponto assegura às crianças surdas o atendimento especializado, mesmo que sejam atendidas por rede regular de creches e pré-escolas, bem como a observância de suas necessidades; e, a garantia de acesso e permanência escolar da criança na escola, mesmo que se faça necessário a elaboração de programas específicos para que este objetivo seja alcançado, assim, a criança surda terá direito a um programa educacional específico que vise seu acesso e permanência escolar, na garantia de prestação educacional efetiva.

LEI $N^{\circ}$ 5.554, DE 16 DE JANEIRO DE 2013: Esta Lei fala da inclusão social e educacional de alunos com deficiência. A proposição "preferencialmente em escolas regulares, sem prejuízo, das escolas 
especiais ou classes especiais" utilizada no artigo $1^{\mathbf{o}^{31}}$, inciso I, nos faz compreender que não é uma obrigatoriedade a matrícula do aluno surdo no ensino regular, cabendo ao responsável pelo aluno analisar o que é melhor para ele e o que melhor atenderá às suas necessidades, se o ensino especializado ou o ensino regular.

E, no mesmo artigo, no inciso II, a expressão "garantir", em se tratando do acesso, permanência e desenvolvimento escolar do aluno compele ao Poder Público fornecer condições para que os interessados consigam ingressar na instituição de ensino e o direito de nela permanecer, sendo vedada a exclusão arbitrária do aluno, propiciando o ambiente essencial para que o aluno se desenvolva.

Já o inciso IV deve ser observado com muita cautela, pois determina a priorização de vagas nas escolas mais próximas à residência do educando. A grande dificuldade, porém, é encontrar instituições de ensino próximas que atendam às necessidades do aluno surdo. Priorizam-se as vagas, mas muitas vezes estas instituições próximas não estão preparadas para recebêlos. Daí a importância de se atender ao inciso III que diz da "qualificação continuada e especializada dos professores".

Faz jus o destaque do inciso II, do artigo $2^{\circ}$, o qual esclarece que para fins de aperfeiçoamento e sustentabilidade das diretrizes estabelecidas no $\operatorname{art.} 1^{\circ}$, o Poder Público desenvolverá ações que prestigiem o planejamento estratégico para estimular o desenvolvimento e aprendizagem do aluno segundo as necessidades educacionais de cada um, e sua inclusão social e educacional (Rio de Janeiro, Município, Lei $\mathrm{n}^{\circ} 5.554$, de 16 de

\footnotetext{
31 "Art. $1^{\circ}$ As ações públicas de educação voltadas aos alunos com deficiência, transtornos globais do desenvolvimento, altas habilidades/superdotação e/ou dificuldades de aprendizagem no âmbito do Município deverão observar as seguintes diretrizes: I - instituição da Educação Especial na perspectiva inclusiva, na Educação Infantil e Ensino Fundamental da Educação Básica, preferencialmente em escolas regulares, sem prejuízo, das escolas especiais ou classes especiais continuarem a prover a educação mais adequada aos alunos com deficiência que não possam ser adequadamente atendidos em turmas comuns ou escolas regulares; II - garantir a permanência, a acessibilidade e o desenvolvimento escolar dos alunos com deficiência, transtornos globais do desenvolvimento, altas habilidades/superdotação e/ou dificuldades de aprendizagem; III qualificação continuada e especializada dos professores; IV - prioridade de oferta de vagas aos alunos com deficiências em unidades escolares próximas à residência do aluno." (Rio de Janeiro, Município, Lei no 5.554 , de 16 de janeiro de 2013, art. $1^{\circ}$ )
} 
janeiro de 2013, art. $2^{\circ}$ ). Um ensino especializado de forma atender as necessidades do aluno é a melhor maneira de respeitar as capacidades deste e permitir seu progresso e aquisição de conhecimento, e este é o reconhecimento legal disto.

Este mesmo artigo, nos inciso IV e V, traz ainda a visão multidisciplinar e avaliações periódicas que busquem constatar a evolução do aluno e se há necessidade de um ensino especializado, indica que a prioridade do ensino é o aluno, e sua evolução é importante, devendo assim as formas de ensino se adaptarem a ele para que seja mais efetiva e dê resultados satisfatórios. Uma avaliação periódica pode verificar se o objetivo está sendo cumprido. 


\title{
4. DA TUTELA JURISDICIONAL: MECANISMOS PROCESSUAIS DE ACESSO AO DIREITO À EDUCAÇÃO
}

\begin{abstract}
"Quando eu aceito a língua de sinais, eu aceito o surdo, $e$ é importante ter sempre em mente que o surdo tem o direito de ser surdo. Nós não devemos muda-los; devemos ensina-los, ajuda-los, nós temos que permitir-lhes ser surdo."
\end{abstract}

(Terje Basilie)

Por muito tempo se discutiu a possibilidade de exigibilidade dos direitos sociais e sua tutela jurisdicional. Por outro lado do reconhecimento de direitos vai a limitação do Direito. É um equilíbrio entre a realidade e o idealismo jurídico. Ao passo que se reconhece que não devem haver normas inalcançáveis, também não se pode pôr completa esperança de que as leis podem resolver todos os problemas da sociedade. O Direito deve caminhar junto com a realidade fática.

É bem sabido que as Constituições falham nos seus objetivos, e por vezes não conseguem conter de forma eficiente o processo político e social (Barroso, 2009, p. 57), a própria realidade contextual da sociedade impõe alguns limites, no entanto, o que nela se dispõe é expressão do poder constituinte originário, portanto, representa um clamor social, e constituem normas jurídicas, regras de direito, que devem produzir efeito na realidade social e cumprir seus desígnios nela estabelecidos, assim correspondendo às suas expectativas ${ }^{32}$.

A Constituição Brasileira abraçou o desafio de recuperar anos de atraso, superando todos as cicatrizes dos modelos ditatoriais anteriores,

\footnotetext{
${ }^{32}$ Barroso traz algumas das razões para uma disposição constitucional não ser cumprida: "Em certos casos, ela se apresenta desde o primeiro momento como irrealizável. De outras vezes, o próprio poder constituído impede sua concretização, por contrariar-lhe o interesse político. E, ainda, um preceito constitucional frustra-se em sua realização por obstáculos opostos por injunções de interesse de segmentos econômicos e politicamente influentes." (Barroso, 2009, p. 61). Se o problema apresentado for a primeira hipótese, pode ser uma insuficiência no texto, que caberá emenda ou reforma no entendimento para que expresse a vontade popular. Quanto as demais, devem ser promovidos meios de garantia de acesso ao direito, em detrimento de toda e qualquer maneira de impedir seu pleno exercício.
} 
finalmente conduzindo o país ao verdadeiro Estado Democrático de Direito, e para isso não se aceitaria uma Constituição que não fosse normativa. A Constituição normativa "é aquela não apenas juridicamente válida, mas que está, além disso, vivamente integrada na sociedade”. Ela é efetiva.

Com isso, já não restam dúvidas de que o direito fundamental social constitui instrumento jurídico de controle da atuação estatal, ele empodera o destinatário da norma dos meios jurídicos para impor ao Estado a execução de programas e ações governamentais a fim de realizarem a Constituição Brasileira. Vai além da exigência de ação de particulares.

O controle judicial é o meio de se garantir a efetividade das normas. Se o Poder Público não atuou como deveria, ou se as políticas adotadas se mostrarem insuficientes, faz-se necessária a existência de mecanismos capazes de fazer com que as normas jurídicas de exigências abstratas dirigidas à vontade humana, se transformem em ações concretas (Barroso, 2009, p. 119).

Sobre o papel do Poder Judiciário neste contesto, leciona Luís Roberto Barroso:

"As garantias jurídicas, ao ângulo subjetivo, correspondem aos meios processuais
de proteção dos direitos, vale dizer, às ações - e respectivos procedimentos -
dedutíveis perante o Poder Judiciário. A ele cabe prestar a jurisdição, que é a
atividade estatal destinada a fazer atuar o direito objetivo, promovendo a tutela
dos interesses violados ou ameaçados. A função jurisdicional é, tipicamente, de
restauração da ordem jurídica, quando vulnerada, e destina-se à formulação e à
atuação prática da norma concreta que deve disciplinar determinada situação."
(2009, p. 121)

Diz ainda o autor:

"Busca-se, assim, sistematizar os mecanismos diversos de exigência do cumprimento do 'compromisso' constitucional, subvertendo sua inspiração falaciosa em uma atuação real e efetiva.” (Ibid., 2009, p.122)

$\mathrm{O}$ artigo $5^{\circ}$, inciso $\mathrm{XXXV}$, da $\mathrm{CRFB}$ nos alude que "a lei não excluirá da apreciação do Poder Judiciário lesão ou ameaça a direito", por conseguinte, qualquer pessoa que se ver nessas condições tem o direito de recorrer ao judiciário que através de sua atuação jurisdicional submeterá o Estado às exigências do ordenamento jurídico. 
Segundo José Eduardo Faria o papel desenvolvido pelo Poder Judiciário neste processo é de grande importância, tendo papel fundamental para que haja cidadania e justiça social:

"Mais ainda: o juiz passa a integrar o circuito de negociação política. Garantir as políticas públicas, impedir o desvirtuamento privatista das ações estatais, enfrentar o processo de desinstitucionalização dos conflitos - apenas para arrolar algumas hipóteses de trabalho - significa atribuir ao magistrado uma função ativa no processo de afirmação da cidadania e da justiça substantiva." (Faria, 2002, p.49)

Devemos ter em mente que se trata de direitos fundamentais, aqueles indispensáveis para a dignidade humana. Seria uma lástima haver positivado o direito sem que houvesse meio de garanti-lo, fazendo com que os destinatários da norma estivessem sujeitos à boa vontade de particulares e principalmente do Estado em fazer valer tais direitos ${ }^{33}$. Dispensa-se, neste momento, quaisquer tipos de classificações que venham amenizar o caráter impositivo destes direitos, conforme leciona Maria do Socorro Azevedo Queiroz:

“[...] em relação aos direitos fundamentais, todos eles, tendo a função de realizar o indivíduo em sociedade, ora será necessário observá-los na sua perspectiva de defesa, ora na sua perspectiva prestacional. Então, o que poderia diferenciar um direito fundamental de outro não é sua qualificação de individual ou social, concreto ou programático, de defesa ou prestacional, mas sua indispensabilidade à dignidade humana." (2011, p. 34)

Ainda que as normas de direitos fundamentais sociais sejam reconhecidamente normas programáticas, não são por isso destituídas de seu caráter imperativo ${ }^{34}$, não é isto que vai lhes diferenciar das demais normas constitucionais. São disposições com força de norma. Nenhum

\footnotetext{
${ }^{33}$ Ressalte-se este ponto, pois para parte da doutrina, as normas de direito social de caráter prestacional são normas programáticas, ou seja, estabelecem apenas diretrizes e metas que devem ser alcançadas de forma mediata, dependendo de lei regulamentadora para ter eficácia. O que representariam um impasse ao pleito em juízo de tais direitos. Conforme leciona Maria do Socorro Azevedo Queiroz: "Tais dificuldades impedem, segundo se posiciona boa parte da doutrina [...], esses direitos de serem pleiteados diretamente no Judiciário a partir das normas insertas na Constituição do Brasil, por exigirem programas legislativos e/ou executivos anteriores para sua configuração como direitos plenos. Para essa parte da doutrina, os direitos fundamentais sociais prestacionais são direitos programáticos, estipulados em normas programáticas.” (Queiroz, 2011, p. 42)

${ }_{34}$ Ainda que se reconheça um grau menor de imperatividade com relação às demais normas, é importante mencionar esta característica para que não suponham que esta categoria de direitos são apenas programas, contudo são dotadas de eficácia jurídica.
} 
dispositivo constitucional é apenas sentimento de justiça.

Consequentemente, à sua inobservância corresponderá instrumentos que garantirão o cumprimento forçado da norma ${ }^{35}$.

A autora supramencionada defende ainda que as normas de direitos sociais são "definidoras de direitos prima facie e não de programas, assim como os direitos subjetivos que partem delas" (Ibid., 2011, p. 71), pois “programas legislativos ou programas de ação legislativos ou executivos são apenas meios de tornar melhor exequíveis os objetos dos direitos constitucionais, em particular dos fundamentais" (Ibid., 2011, p. 71). E os direitos sociais teriam ainda uma dimensão subjetiva, o que faz com que independentemente de haver meios constitucionais de assegurar sua eficácia, são uma imposição constitucional a sua prestação, incorrendo na possibilidade de exigência na falta de ações que os concretize.

No caso do direito social à educação, o que ocorre quando o Poder Público não promove políticas públicas de acesso aos direitos sociais é que o mercado se impõe e com isso é favorecida apenas parte da população, setores específicos, que têm condições de acesso ao mercado e para tal se apropriam do direito. Assim, o direito social não é universalizado. Gerando uma massa de pessoas que não alcançaram o desenvolvimento pessoal, despreparadas para exercer a cidadania e desqualificadas para o trabalho, que se veem obrigadas a se submeter às injustiças sociais de uma vida indigna $^{36}$.

E de maneira alguma a afirmativa de que esta atuação do Judiciário seria uma forma de intervenção no Poder Executivo poderia constituir uma assertiva. Uma vez que é o papel do Poder Judiciário a garantia de direitos,

\footnotetext{
${ }^{35}$ Jayme Benvenuto Lima Jr., ainda afirma que é justamente a imperatividade destas normas que lhes dão o caráter de direitos humanos. De acordo com o trecho a seguir: "Os direitos humanos econômicos, sociais e culturais - como os direitos humanos em geral - devem se fazer acompanhar de diversas formas de realização ou de exigibilidade para merecerem a denominação de direitos humanos. Esse é um imperativo do qual não se pode fugir, sob pena de se ver os direitos humanos reduzidos a meras normas programáticas ou a valores jusnaturalistas." (Lima Jr., 2001, p. 95)

${ }^{36}$ Isto quando o Estado não oferece condições necessárias, porém não estamos trabalhando com ideias fantasiosas e sabemos que há pessoas que não alcançaram ou não alcançarão tais objetivos não por força da atuação ou omissão estatal, mas por força de outros fatores, muitas vezes fatores internos. No entanto, o Estado não deve deixar de promovê-lo.
} 
e para isto desempenhará diversos papéis, aqui reafirma a regra prescrita e busca a observância dos direitos fundamentais como valores intrínsecos. Para este fim, muitas vezes o Judiciário precisará ir contra interesses do governo em favor dos sujeitos, prestando sua tutela jurídica, impondo a movimentação da máquina estatal em sentido daquele fim constitucionalmente estabelecido.

Além de que, o princípio da separação de poderes $^{37}$ de maneira alguma pretende justificar ou proteger as omissões do Poder Executivo. $\mathrm{O}$ que o Poder Judiciário faz é o controle da atuação, fiscalização quanto à observância das normas e impulsionar a máquina estatal, sem em momento algum substituí-la.

Queiroz diz ainda que as normas de direito fundamentais sociais prestacionais são imperativas autorizantes, as quais permitem que o sujeito de direito, a pessoa afetada, pretenda seu objeto, ainda que lhe faltem meios eficazes de coagir o agente a cumpri-lo. Cita ainda o exemplo de uma sociedade que não tem uma educação de base adequada, pela norma

\footnotetext{
${ }^{37}$ Neste sentido caminha o entendimento no STF, como demonstram os agravos regimentais abaixo colacionados:

"Agravo regimental em recurso extraordinário com agravo. Implementação de políticas públicas. Deterioração das instalações de instituição pública de ensino. Construção de nova escola. Possibilidade. Inexistência de violação ao princípio da separação dos poderes. Garantia do direito à educação básica. Precedentes. As duas turmas do Supremo Tribunal Federal possuem entendimento de que é possível ao Judiciário, em situações excepcionais, determinar ao Poder Executivo a implementação de políticas públicas para garantir direitos constitucionalmente assegurados, a exemplo do direito ao acesso à educação básica, sem que isso implique ofensa ao princípio da separação dos Poderes. Precedentes. Agravo regimental a que se nega provimento." (STF - ARE: 761127 AP, Relator: Min. Roberto Barroso, Data de Julgamento: 24/06/2014, Primeira Turma, Data de Publicação: Acórdão eletrônico DJe-158 Divulg 15-08-2014 Public 1808-2014)

No mesmo entendimento:

"Agravo regimental em recurso extraordinário com agravo. Implementação de políticas públicas. Instalações de instituição pública de ensino em condições precárias. Determinação de reforma pelo poder judiciário. Possibilidade. Inexistência de violação ao princípio da separação dos poderes. Garantia do direito à educação e à segurança. Precedentes. A jurisprudência do Supremo Tribunal Federal é firme no sentido de que, em casos emergenciais, é possível a implementação de políticas públicas pelo Judiciário, ante a inércia ou morosidade da Administração, como medida assecuratória de direitos fundamentais. Precedentes. Para dissentir da conclusão firmada pelo Tribunal de origem no sentido de que houve, ou não, inércia do Poder Público estadual em relação à manutenção de instituto de educação, seria necessário nova apreciação dos fatos e do material probatório constantes dos autos. Incidência da Súmula 279/STF. Precedentes. Ausência de argumentos capazes de infirmar a decisão agravada. Agravo regimental a que se nega provimento." (STF - ARE: 845392 RS, Relator: Min. Roberto Barroso, Data de Julgamento: 09/12/2014, Primeira Turma, Data de Publicação: Acórdão eletrônico DJe-021 DIVULG 30-012015 PUBLIC 02-02-2015)
} 
constitucional do artigo $6^{\circ}$, da $\mathrm{CRFB}$, estão autorizadas a pleitear no Judiciário medidas que ponham fim à omissão estatal (Queiroz, 2011, p. 49).

Outro argumento muito utilizado por doutrinadores contrários à exigibilidade judicial dos direitos fundamentais sociais é o de que tais direitos estariam fora do âmbito jurídico de atuação, seriam, portanto, de âmbito político, submetidos aos atos do legislador. Inclusive por implicar questões financeiras. No entanto, no caso concreto é que deve ser ponderada a limitação, como qualquer ponderação de princípios.

Os direitos sociais buscam a melhor forma de prestação, no entanto, em confronto com outras necessidades, no caso concreto, deverá se ponderar sua limitação. Isto não quer dizer que será sempre limitado ou sempre prevalecerá frente aos demais direitos, mas que a melhor realização do direito deve ser privilegiada de acordo com a necessidade que se impõe.

Cabe frisar que sendo os direitos sociais categoria de direitos humanos, há a necessidade de adequação às normas internacionais de direitos humanos ratificadas pelo Brasil, “ao Estado cabe, por força dos próprios tratados internacionais, demonstrar as ações desenvolvidas para reverter a situação de desrespeito a tais direitos" (Lima Jr., 2001, p. 96), uma vez que tratados sobre matéria de direitos humanos são internalizados com força de dispositivo constitucional.

No Decreto $n^{\circ}$. 591, de 6 de julho de 1992, o Brasil promulgou o Pacto Internacional de Direitos Econômicos, Sociais e Culturais. É uma de suas disposições com relação a educação:

\footnotetext{
"Artigo 13: 1. Os Estados Partes do presente Pacto reconhecem o direito de toda pessoa à educação. Concordam em que a educação deverá visar ao pleno desenvolvimento da personalidade humana e do sentido de sua dignidade e fortalecer o respeito pelos direitos humanos e liberdades fundamentais. Concordam ainda em que a educação deverá capacitar todas as pessoas a participar efetivamente de uma sociedade livre, favorecer a compreensão, a tolerância e a amizade entre todas as nações e entre todos os grupos raciais, étnicos ou religiosos e promover as atividades das Nações Unidas em prol da manutenção da paz. [...]” (Brasil, Decreto nº. 591 de 1992)
} 
Esta é a ideia principal da exigibilidade da realização de tais direitos, a garantia de padrões mínimos de vida digna para todos, para além dos obstáculos econômicos (Lima Jr., 2011, p. 96), o direito ao desenvolvimento é um imperativo ético (Ibid., 2011, p. 97), a limitação dos recursos financeiros não justificam a não realização destes. Tais direitos, quando efetivados, representam a concretização da dignidade humana. Por isso, o Estado deve disponibilizar todos os recursos possíveis que detém na realização destes ${ }^{38}$.

Com esta finalidade existem mecanismos jurídicos, os remédios e ações constitucionais dos quais falaremos a seguir.

\subsection{Ação Direta de Inconstitucionalidade por Omissão - ADI por Omissão}

A ADI por Omissão é reflexo da percepção de que não se infringe a Constituição Federal apenas ao editar normas inconstitucionais, mas também quando não a regulamenta, a ausência de norma regulamentadora. Assim, não é qualquer omissão que enseja ADI por Omissão, porquanto não caberá na ocasião em que editar a norma seja mera faculdade ou a determinação for de realização de política pública, mas sim omissão à regulamentação determinada pela Constituição Federal quanto a tornar efetiva a norma constitucional.

As normas de processo e julgamento das ADIs por Omissão estão dispostas na Lei $\mathrm{n}^{\circ}$. 9868, de 10 de novembro de 1999. Porém, é o artigo $103, \S 2^{\circ}$, da CRFB que lhe possibilita, consoante dispositivo infra:

“Art. 103. Podem propor a ação direta de inconstitucionalidade e a ação declaratória de constitucionalidade:

\footnotetext{
38 Conforme artigo 2º 1 , do PIDESC: “Artigo 2: 1 . Cada Estado Parte do presente Pacto compromete-se a adotar medidas, tanto por esforço próprio como pela assistência e cooperação internacionais, principalmente nos planos econômico e técnico, até o máximo de seus recursos disponíveis, que visem a assegurar, progressivamente, por todos os meios apropriados, o pleno exercício dos direitos reconhecidos no presente Pacto, incluindo, em particular, a adoção de medidas legislativas." (Brasil, PIDESC), frise-se que diz "até o máximo de seus recursos disponíveis".
} 
$[\ldots]$

$\S 2^{\circ}$ Declarada a inconstitucionalidade por omissão de medida para tornar efetiva norma constitucional, será dada ciência ao Poder competente para a adoção das providências necessárias e, em se tratando de órgão administrativo, para fazê-lo em trinta dias.

[...].” (Brasil, Constituição Federal, 1988)

Da mesma forma, possibilita ADI por Omissão a inércia frente disposição de tratado ou convenção que foram incorporados ao ordenamento jurídico interno, a saber, os tratados ou convenções de direitos humanos, os quais sendo rafiticados na forma do artigo $5^{\circ}, \S 3^{\circ}$, da CRFB ganham caráter de dispositivo constitucional. Conforme abaixo aludido:

"Art. $5^{\circ}$ Todos são iguais perante a lei, sem distinção de qualquer natureza, garantindo-se aos brasileiros e aos estrangeiros residentes no País a inviolabilidade do direito à vida, à liberdade, à igualdade, à segurança e à propriedade, nos termos seguintes:

[...]

$\S 3^{\circ}$ Os tratados e convenções internacionais sobre direitos humanos que forem aprovados, em cada Casa do Congresso Nacional, em dois turnos, por três quintos dos votos dos respectivos membros, serão equivalentes às emendas constitucionais.

[...]" (Brasil, Constituição Federal)

O Decreto $\mathrm{n}^{\mathrm{o}}$. 6.949, de 25 de agosto de 2009, promulgou a Convenção sobre os Direitos das Pessoas com Deficiência e seu Protocolo Facultativo de 2007, e os aprovou, por meio do Decreto Legislativo no ${ }^{\circ}$ 186, de 9 de julho de 2008, conforme o procedimento do $\S 3^{\circ}$ do art. $5^{\circ}$ da Constituição, esta Convenção. Publicado no Diário Oficial da União em 26 de agosto de 2009, seção $1, n^{\circ} .163$, p. 3.

Sendo assim, podemos afirmar que o a Convenção supra tendo percorrido todo o procedimento estabelecido pela Constituição federal, o mesmo procedimento que para aprovação de Emendas Constitucionais, recebeu status de dispositivo constitucional. Portanto, qualquer norma ou a omissão frente a sua norma que se estabelecer, será passível de ADI, e, no caso, ADI por Omissão.

No artigo 4, "1", “a”, da Convenção acima mencionada o Estado Brasileiro (assim como os demais Estados Partes) se compromete a adotar 
"medidas legislativas" que tornem efetivos os direitos reconhecidos por ela. Segundo preceito infra colacionado:

\section{"Artigo 4}

Obrigações gerais

1.Os Estados Partes se comprometem a assegurar e promover o pleno exercício de todos os direitos humanos e liberdades fundamentais por todas as pessoas com deficiência, sem qualquer tipo de discriminação por causa de sua deficiência. Para tanto, os Estados Partes se comprometem a:

a) Adotar todas as medidas legislativas, administrativas e de qualquer outra natureza, necessárias para a realização dos direitos reconhecidos na presente Convenção; [...].” (Brasil, Decreto no . 6.949 de 2009)

Podemos assim compreender que este é um dispositivo de natureza constitucional que demanda regulamentação, e não de forma facultativa, mas há o comprometimento em adotar tais medidas, é uma imposição a composição de regulamentação necessária para efetivar os direitos reconhecidos por ela.

E um dos direitos reconhecidos é o direito das pessoas com deficiência, leia-se, da pessoa surda, de ter assegurado pelo Estado a facilitação do aprendizado da língua de sinais, leia-se, Libras, bem como de toda a Cultura Surda, reconhecendo que este é o ápice do reconhecimento de uma identidade, o ser surdo.

\footnotetext{
"Artigo 24

Educação

[...]

3. Os Estados Partes assegurarão às pessoas com deficiência a possibilidade de adquirir as competências práticas e sociais necessárias de modo a facilitar às pessoas com deficiência sua plena e igual participação no sistema de ensino e na vida em comunidade. Para tanto, os Estados Partes tomarão medidas apropriadas, incluindo:

[...]

b) Facilitação do aprendizado da língua de sinais e promoção da identidade lingüística da comunidade surda;

[...]" (Brasil, Decreto n ${ }^{\circ} .6 .949$ de 2009)

Portanto, é admissível que na ausência de norma que regulamente tal dispositivo, dizendo quais as medidas a serem adotadas para o exercício do direito acima descrito, seja proposta ADI por Omissão.
} 
A legitimidade para mover uma ADI por omissão será de qualquer um dos legitimados apresentados no rol taxativo do artigo 103 da Constituição Federal.

A ação deverá ser proposta perante o $\mathrm{STF}^{39}$, que será seu julgador, e sua decisão terá efeito erga omnes $^{40}$, em concordância com o que foi estabelecido na Constituição Federal.

\subsection{Mandado de Injunção - MI}

Este remédio constitucional também vai se operar mediante omissão legislativa, porém são muitas as diferenças da ação constitucional vista anteriormente. Os professores Motta e Barchet (2007, p. 855, 856) trazem de forma bem didática suas distinções da ADI por Omissão, as quais enumeramos a seguir:

a) quanto ao conceito: o MI é remédio constitucional que visa a defesa de direitos definidos em sede constitucional que carecem de norma regulamentadora, enquanto a ADI por Omissão é ação que, por meio de controle abstrato, visa a defesa do texto constitucional; b) quanto ao objeto: do MI são apenas os direitos fundamentais, mesmo que não estejam no Título II, mas que sejam reconhecidos na Constituição Federal, já da ADI por Omissão é qualquer norma constitucional originária ou derivada, de eficácia limitada por ausência de norma que regulamente;

c) quanto à legitimidade ativa: do MI é apenas o titular do direito fundamental carente de norma regulamentadora, e da ADI por

\footnotetext{
39 “Art. 102. Compete ao Supremo Tribunal Federal, precipuamente, a guarda da Constituição, cabendo-lhe: I - processar e julgar, originariamente: a) a ação direta de inconstitucionalidade de lei ou ato normativo federal ou estadual e a ação declaratória de constitucionalidade de lei ou ato normativo federal; [...]" (Ibid., art. 102)

40 “Art. 102. Compete ao Supremo Tribunal Federal, precipuamente, a guarda da Constituição, cabendo-lhe: [...] § $2^{\circ}$ As decisões definitivas de mérito, proferidas pelo Supremo Tribunal Federal, nas ações diretas de inconstitucionalidade e nas ações declaratórias de constitucionalidade produzirão eficácia contra todos e efeito vinculante, relativamente aos demais órgãos do Poder Judiciário e à administração pública direta e indireta, nas esferas federal, estadual e municipal. [...]" (Ibid., 102)
} 
Omissão são todos os legitimados do rol taxativo do artigo 103, da CRFB;

d) quanto ao juízo competente: no MI será determinada de acordo com o legitimado passivo a competência para processar e julgar, numa espécie de sistema difuso, ao passo que na ADI por Omissão, é adotado o sistema concentrado, como típico do controle abstrato;

e) quanto à natureza jurídica do procedimento: o MI segue o rito sumário próprio de um procedimento judicial, já na ADI por Omissão é um processo de controle de constitucionalidade ${ }^{41}$.

É o artigo $5^{\circ}$, inciso LXXI, da CRFB, que dá possibilidade ao Mandado de Injunção. Como se segue: “Art. $5^{\circ}$ Todos são iguais perante a lei, sem distinção de qualquer natureza,
garantindo-se aos brasileiros e aos estrangeiros residentes no País a
inviolabilidade do direito à vida, à liberdade, à igualdade, à segurança e à
propriedade, nos termos seguintes:
[...]
LXXI - conceder-se-á mandado de injunção sempre que a falta de norma
regulamentadora torne inviável o exercício dos direitos e liberdades
constitucionais e das prerrogativas inerentes à nacionalidade, à soberania e à
cidadania;
[...]” (Ibid., art. $5^{\circ}$ )
E são quatro as possibilidades de efeitos da decisão: (i) a posição
antiga do STF, na qual a decisão do Poder Judiciário teria efeitos apenas
declaratórios, reconhecendo que de fato houve a omissão ${ }^{42}$; (ii) a

\footnotetext{
${ }^{41}$ Contudo, a propositura de um não obsta a propositura de outro, visto que são "os dois procedimentos convergentes para combater a inércia do órgão regulamentador" (Motta \& Barchet, 2007, p. 856).

${ }^{42}$ Conforme entendimento abaixo colacionado:

"Mandado de injunção. Natureza. O mandado de injunção nem autoriza o judiciário a suprir a omissão legislativa ou regulamentar, editando o ato normativo omitido, nem, menos ainda, lhe permite ordenar, de imediato, ato concreto de satisfação do direito reclamado: mas, no pedido, posto que de atendimento impossível, para que o tribunal o faça, se contém o pedido de atendimento possível para a declaração de inconstitucionalidade da omissão normativa, com ciência ao órgão competente para que a supra. Créditos judiciais contra a fazenda pública: pagamento parcelado (ADCT, art. 33): faculdade do poder executivo. O art. 33 do ADCT de 1988 não outorgou direito ao credor da fazenda pública ao pagamento parcelado nele previsto, ao contrário, como faculdade do poder executivo competente, extinta com o transcurso do prazo decadencial de 180 dias sem decisão a respeito; a omissão dela, por conseguinte, não dá margem a mandado de injunção.” (STF - MI: 168 RS, Relator: Sepúlveda Pertence, data de julgamento: 21/03/1990, Tribunal Pleno, Data de publicação: DJ 20-04-1990)
} 
possibilidade de o Poder Judiciário atuar como se legislador fosse suprindo assim a lacuna deixada pela ausência da $\mathrm{Lei}^{43}$, tendo sua decisão efeitos

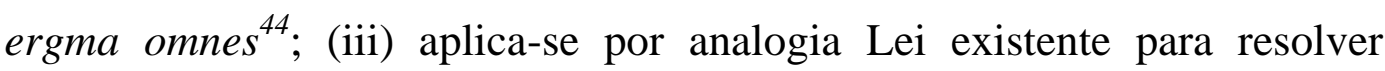
aquele caso $^{45}$, baseando-se nos princípios constitucionais e na equidade, tendo, assim, efeito inter partes; (iv) a hipótese em que a decisão reconhece a omissão e comunica ao órgão responsável pela edição da Lei, fixando-lhe prazo para sua feitura ${ }^{46}$.

\footnotetext{
${ }^{43}$ Foi o entendimento no MI que se segue:

"Mandado de injunção. Garantia fundamental (CF, art. $5^{\circ}$, inciso LXXI). Direito de greve dos servidores públicos civis (CF, art. 37, inciso VII). Evolução do tema na jurisprudência do Supremo Tribunal Federal (STF). Definição dos parâmetros de competência constitucional para apreciação no âmbito da justiça federal e da justiça estadual até a edição da legislação específica pertinente, nos termos do art. 37, VII, da CF. Em observância aos ditames da segurança jurídica e à evolução jurisprudencial na interpretação da omissão legislativa sobre o direito de greve dos servidores públicos civis, fixação do prazo de 60 (sessenta) dias para que o congresso nacional legisle sobre a matéria. Mandado de injunção deferido para determinar a aplicação das leis nos 7.701/1988 e 7.783/1989. 1. Sinais de evolução da garantia fundamental do mandado de injunção na jurisprudência do Supremo Tribunal Federal (STF). [...] 6.7. Mandado de injunção conhecido e, no mérito, deferido para, nos termos acima especificados, determinar a aplicação das Leis nos 7.701/1988 e 7.783/1989 aos conflitos e às ações judiciais que envolvam a interpretação do direito de greve dos servidores públicos civis." (STF - MI: 670 ES, Relator: Maurício Corrêa, Data de Julgamento: 25/10/2007, Tribunal Pleno, Data de Publicação: DJe-206 Divulg. 30-10-2008 Publicação: 31-10-2008)

${ }^{44}$ Esta posição é muito criticada por, supostamente, ferir o princípio da separação dos poderes.

${ }^{45}$ De acordo com entendimento a seguir:

"Mandado de injunção natureza. Conforme disposto no inciso LXXI do artigo $5^{\circ}$ da Constituição Federal, conceder-se-á mandado de injunção quando necessário ao exercício dos direitos e liberdades constitucionais e das prerrogativas inerentes à nacionalidade, à soberania e à cidadania. Há ação mandamental e não simplesmente declaratória de omissão. A carga de declaração não é objeto da impetração, mas premissa da ordem a ser formalizada. Mandado de injunção decisão balizas. Tratando-se de processo subjetivo, a decisão possui eficácia considerada a relação jurídica nele revelada. Aposentadoria trabalho em condições especiais prejuízo à saúde do servidor Inexistência de lei complementar Artigo 40, $4^{\circ}$, Da Constituição Federal. Inexistente a disciplina específica da aposentadoria especial do servidor, impõe-se a adoção, via pronunciamento judicial, daquela própria aos trabalhadores em geral artigo $57, \S 1^{\circ}$, da Lei $n^{\circ} 8.213 / 91$. Aposentadoria especial servidor público trabalho em ambiente insalubre parâmetros. Os parâmetros alusivos à aposentadoria especial, enquanto não editada a lei exigida pelo texto constitucional, são aqueles contidos na Lei no 8.213/91, não cabendo mesclar sistemas para, com isso, cogitar-se de idade mínima." (STF - MI: 960 DF, Relator: Min. Marco Aurélio, Data de Julgamento: 05/06/2014, Tribunal Pleno, Data de Publicação: Acórdão eletrônico DJe-148 Divulg. 31-07-2014 Publicação 01-08-2014)

${ }^{46}$ Como está exemplificado no caso do MI a seguir:

"Mandado de injunção. Artigo $8^{\circ}, \S 3^{\circ}$ do ADCT. Direito à reparação econômica aos cidadãos alcançados pelas portarias reservadas do ministério da aeronáutica. Mora legislativa do congresso nacional. [...] Logo, desnecessária a renovação de notificação ao órgão legislativo que, no caso, não apenas incidiu objetivamente na omissão do dever de legislar, passados quase quatorze anos da promulgação da regra que lhe criava tal obrigação, mas que, também, já foi anteriormente cientificado por esta Corte, como resultado da decisão de outros mandados de injunção. [...] 3 Reconhecimento da mora legislativa do Congresso Nacional em editar a norma prevista no parágrafo $3^{\circ}$ do art. $8^{\circ}$ do ADCT, assegurando-se, aos impetrantes, o exercício da ação de reparação patrimonial, nos termos do direito comum ou ordinário, sem prejuízo de que se venham, no futuro, a beneficiar de tudo quanto, na lei a ser editada, lhes possa ser mais favorável que o disposto na decisão judicial. O pleito deverá ser veiculado diretamente mediante ação de
} 


\subsection{Mandado de Segurança - MS}

Este remédio constitucional disciplinado pela Lei $\mathrm{n}^{\circ}$. 12.016, de 07 de agosto de 2009, é previsto no artigo $5^{\circ}$, da CRFB: "Art. $5^{\text {o }}$ Todos são iguais perante a lei, sem distinção de qualquer natureza,
garantindo-se aos brasileiros e aos estrangeiros residentes no País a
inviolabilidade do direito à vida, à liberdade, à igualdade, à segurança e à
propriedade, nos termos seguintes:
[...]
LXIX - conceder-se-á mandado de segurança para proteger direito líquido e certo,
não amparado por habeas corpus ou habeas data, quando o responsável pela
ilegalidade ou abuso de poder for autoridade pública ou agente de pessoa jurídica
no exercício de atribuições do Poder Público;

[...]"(Ibid., art. $5^{\circ}$ )

O MS decorre do princípio de que "a lei não excluirá da apreciação do Poder Judiciário lesão ou ameaça a direito" (art. 5 inciso XXXV, da CRFB). Sua finalidade é proteger direito líquido e certo, ou seja, aquele que pode ser comprovado de forma inequívoca, diante de atuação da Administração Pública de forma ilegal.

A Constituição Federal diz no caput ${ }^{47}$ do seu artigo 37 , que todo e qualquer ato da Administração Pública deve ser baseado no princípio da legalidade, o que quer dizer que todo e qualquer ato seu deve ser amparado por Lei, diferentemente do que é posto aos cidadãos, a Administração Pública não pode fazer o que a Lei não proíbe, mas sim apenas o que a Lei autoriza.

Desta forma, o agente administrador público incorrerá em tal hipótese quando atuar de forma excedente ao poder lhe outorgado, atuando além do que foi delimitado por sua competência ou quando não atuar no

liquidação, dando-se como certos os fatos constitutivos do direito, limitada, portanto, a atividade judicial à fixação do "quantum" devido. [...]" (STF - MI: 562 RS, Relator: Carlos Velloso, Data de Julgamento: 20/02/2003, Tribunal Pleno, Data de Publicação: DJ 20-06-2003)

47 “Art. 37. A administração pública direta e indireta de qualquer dos Poderes da União, dos Estados, do Distrito Federal e dos Municípios obedecerá aos princípios de legalidade, impessoalidade, moralidade, publicidade e eficiência e, também, ao seguinte:” (Brasil, Constituição Federal, art. 37) 
interesse público quando esta atuação estiver dentro de suas competências, assim, se desviando de sua finalidade.

O legitimado ativo, para impetrar MS será o titular do direito ou terceiro prejudicado, e o legitimado passivo, para integrar a parte impetrada, é a própria autoridade coatora.

É admissível que este direito líquido e certo seja garantido por meio de norma constitucional ou infraconstitucional. A Lei ${ }^{\circ}$. 13.146, de 06 de julho de 2015, em seu artigo 28, inciso $\mathrm{IV}^{48}$, diz que o Poder Público deve implementar e assegurar a oferta de educação bilíngue (Libras com primeira língua e português, na modalidade escrita, como segunda língua) aos alunos surdos. Portanto, a violação de tal norma em qualquer unidade e âmbito da federação dará ensejo a Mandado de Segurança.

\subsection{Mandado de Segurança Coletivo - MS Coletivo}

Admite-se, da mesma forma, a modalidade do Mandado de Segurança coletivo, no qual estará representado os interesses de uma determinada coletividade. O artigo $5^{\circ}$, inciso LXX e suas alíneas, da CRFB, apresenta a viabilidade deste remédio constitucional e seus legitimados ativos:

\footnotetext{
“Art. $5^{0}$ Todos são iguais perante a lei, sem distinção de qualquer natureza, garantindo-se aos brasileiros e aos estrangeiros residentes no País a inviolabilidade do direito à vida, à liberdade, à igualdade, à segurança e à propriedade, nos termos seguintes:

$[\ldots]$

LXX - o mandado de segurança coletivo pode ser impetrado por:

a) partido político com representação no Congresso Nacional;

b) organização sindical, entidade de classe ou associação legalmente constituída e em funcionamento há pelo menos um ano, em defesa dos interesses de seus membros ou associados;

[...]" (Id., Constituição Federal, art. 5º
}

\footnotetext{
48 “Art. 28. Incumbe ao poder público assegurar, criar, desenvolver, implementar, incentivar, acompanhar e avaliar: [...] IV - oferta de educação bilíngue, em Libras como primeira língua e na modalidade escrita da língua portuguesa como segunda língua, em escolas e classes bilíngues e em escolas inclusivas;" (Id., Lei nº 13.146 de 2015)
} 
Diante deste dispositivo compreende-se a legitimidade das associações de surdos (geralmente associações regionais) para impetrar MS Coletivo em prol do interesse de seus associados, independentemente de autorização destes ${ }^{49}$, desde que esta associação esteja regularmente inscrita, na forma do inciso XXI, do artigo $5^{\circ}$, que diz que "as entidades associativas, quando expressamente autorizadas, têm legitimidade para representar seus filiados judicial ou extrajudicialmente;".

\subsection{Arguição de Descumprimento de Preceito Fundamental - ADPF}

Mais uma ação de origem constitucional, a ADPF pretende evitar ou reparar lesão a preceito fundamental (leia-se, direitos fundamentais, princípios fundamentais, cláusulas pétreas e princípios constitucionais sensíveis $)^{50}$ causada por ato do Poder Público, evitando que tais atos ou normas violadoras de preceitos fundamentais afetem a supremacia constitucional.

Encontra guarida no artigo $102, \S 1^{\circ}$, da CRFB:

"Art. 102. Compete ao Supremo Tribunal Federal, precipuamente, a guarda da Constituição, cabendo-lhe:

[...]

$\S 1^{\circ}$ A argüição de descumprimento de preceito fundamental, decorrente desta Constituição, será apreciada pelo Supremo Tribunal Federal, na forma da lei.

[...]" (Ibid., art. 102)

Esta ação é regulamentada pela Lei $\mathrm{n}^{\circ}$. 9.882, de 3 de dezembro de 1999. O STF será o órgão competente para julgar a ação, sendo legitimados os mesmos da Ação Direta de Inconstitucionalidade, conforme artigo $2^{\circ}$, da Lei 9.882/1999.

\footnotetext{
${ }^{49}$ Isto de acordo com a Súmula no .629 , do STF: "Súmula 629. A impetração de mandado de segurança coletivo por entidade de classe em favor dos associados independe da autorização destes." (Id., Supremo Tribunal Federal, Súmulas do STF)

${ }^{50}$ Sobre isto leciona Barroso: "A locução preceito fundamental, como visto, descreve um conjunto de disposições constitucionais que, embora ainda não conte com uma definição precisa, certamente inclui as decisões sobre a estrutura básica do Estado, o catálogo de direitos fundamentais e os chamados princípios sensíveis. A ADPF, portanto, é um mecanismo vinculado à proteção dos preceitos constitucionais considerados fundamentais" (Barroso, 2011, p. 307), no mais, essa lesão ou ameaça de lesão a preceito fundamental disposto na Constituição Federal deve ser concreta e inequívoca.
} 
Contudo, atente-se para o fato de que a ADPF é ação de caráter residual, ou subsidiário, logo, só deverá ser proposta mediante insuficiência de demais meios processuais para postular tal direito, conforme artigo $4^{\circ}, \S$ $1^{\circ}$, da Lei $9.882 / 1999$. 


\section{DA PESQUISA DE CAMPO}

"Quando perdemos o direito de ser diferentes, perdemos o privilégio de ser livres."

(Charles Evans Hughes)

Esta pesquisa foi realizada mediante o seguinte problema: Compreendendo que a educação deve visar ao pleno desenvolvimento da pessoa, o modelo de educação básica ofertado pelo Poder Público atualmente tem garantido realmente o direito à educação?

É relevante a discussão do tema, pois a prática do modelo de inclusão utilizado atualmente já se mostrou ineficiente na educação de surdos, inclusive mostra-se também despreocupada com a identidade do ser surdo, tratando de forma irrelevante a cultura surda e a Libras, ao invés do reconhecimento desta minoria linguística.

Muito se tem discutido quanto ao modelo ideal de educação para surdos. Apesar de falarmos um pouco do modelo de escola bilíngue para surdos, a qual promove o ensino da Libras como língua materna e meio de ensino das demais áreas do saber, e a língua portuguesa na modalidade escrita como segunda língua, tornando sua forma oral facultativa, a maior preocupação é fazer compreender que o modelo educacional influi diretamente na efetividade do direito à educação, sendo certo que este está associado ao desenvolvimento pleno do indivíduo e não apenas com acesso ao ambiente escolar.

Assim, os objetivos desta pesquisa foram:

a) Sinalizar a efetividade de uma escola bilíngue para: pleno desenvolvimento e respeito da cultura surda; desenvolvimento das aptidões do aluno, acreditando e estimulando suas aptidões;

b) Sinalizar a ineficácia do sistema de inclusão sem adaptação do aluno surdo à cultura surda, mas querendo fazer dele um falso ouvinte; 
c) Reafirmar que tratamento desigual é garantia de igualdade, visto o respeito às diferenças;

d) Sinalizar ao despreparo de muitas escolas em receber alunos surdos;

e) Sinalizar a importância da escola num contexto no qual os familiares não sabem como lidar com as necessidades educacionais do surdo.

E para isso foi desenvolvida uma "roda de conversa" na qual foram colhidos depoimentos de mães de crianças surdas, mediante seis perguntas a serem apresentadas abaixo juntamente com a discussão por elas apresentadas.

A "roda de conversa" foi realizada com a participação de um conjunto de 14 (quatorze) mães ouvintes, todas com seus filhos surdos matriculados em uma mesma instituição de ensino privada. Abaixo seus depoimentos $^{51}$.

A primeira pergunta feita foi: Quando você descobriu a surdez de seu filho, qual foi a sua maior preocupação com relação a educação dele? Respondeu a primeira mãe:

A: A minha maior preocupação foi o preconceito, porque eu vivi isso dentro de casa. Mas eu venci e hoje todo mundo entende que o fato de ele ser implantado ${ }^{52}$, ele continua sendo surdo. Porque acontecia de eles pensarem - a maioria da minha família - que ele iria implantar e iria deixar de ser surdo, e eu, que estava sempre mais por dentro das informações, tentava passar para a minha família que ele iria implantar, sim, mas não iria deixar de ser surdo e a gente tinha que aceitar isso, para o bem dele, para que ele mesmo se aceitasse!

Diante disto, foi perguntado: Sua família toda é de ouvintes? E "A" prosseguiu: "Tenho uma filha também. São os dois surdos. E os outros da minha família toda são ouvintes.”. Mais um questionamento a esta mãe: Então você tinha medo de ele sofrer esse preconceito também na escola? E "A" respondeu:

\footnotetext{
${ }^{51}$ Os nomes das mães e de seus filhos foram substituídos por letras aleatórias do alfabeto para evitar a identificação.

${ }^{52}$ Está falando do implante coclear.
} 
A: Com certeza! Porque um pouquinho, no começo, com certeza ele sofreu, sim! Principalmente depois que ele fez o implante, que falaram [na escola] que ele deveria fechar a boca e jogar a chave fora! $\mathrm{E}$ isso me preocupou muito, quando eu me perguntei: "como é que submeti meu filho a uma cirurgia tão séria e ao mesmo tempo tão importante para o futuro dele, para ajudar com o desenvolvimento e hoje falam para ele que ele tem que fechar a boca e jogar a chave fora?!". Então isso acabou confundindo muito a cabeça dele. Ele disse para mim: "E agora, o que é que eu vou fazer? Faço Libras, falo... O que é que eu faço?". Do meu jeito - que eu ainda não sei dizer muita coisa - tentei explicar para ele que ele poderia, sim, fazer os dois!

Com essa conversa com ele foi que aos poucos ele entendeu que ele não precisava fechar a boca e jogar a chave fora.

Além do preconceito, foram surgindo por parte de outras mães, outras questões, outros receios que estas teriam tido com relação a educação

de seu filho quando foi descoberta a surdez. Disse esta mãe:

B: A minha foi só encontrar uma escola adequada. Eu me engajei aqui, então... Ninguém aqui vai dizer que vai aceitar, "ai aceitei, abracei...", não! A gente aceita porque não tem outra opção, entendeu? Logo no início é um choque! A gente chora... Comigo foi assim, eu chorei, suplicando: "Meu Deus, tem tanta criança para nascer surda, porque logo a minha?". Falei: “Tanta criança por aí e Você foi escolher logo a minha? Meu Deus...”. Falei! Falei porque eu não conhecia quase ninguém surdo! Aí depois que eu vim para esta escola foi que eu entrei no mundo deles.

Mas aí, depois daquele dia, eu chorei, mas disse "se Deus me deu eu vou aceitar!". Agora, todas as oportunidades que eu tive de correr, de ir atrás, de uma melhoria para ela eu abraço e vou! Demorei a fazer o implante? Sim! Por que na época que eu descobri ela tinha um ano... Ia fazer dois anos, eu estava me separando $^{53}$, foi uma fase horrível! Então, ou eu trabalhava, ou eu largava tudo para ir cuidar dela. Então, quem ia me sustentar, eu e ela? Quem? Então demorei treze anos para eu tomar uma atitude para fazer [o implante coclear]. Mas por quê? Porque teve gente de fora que me apoiou, para me ajudar, porque depois que você faz essa cirurgia, você tem uns gastos absurdos, e eu até agora não senti nada no meu bolso porque - graças a Deus - não sou eu quem está pagando.

Diante da segurança apresentada pela mãe, lhe foi perguntado: Porque você disse que aqui encontrou a educação adequada? E esta respondeu:

B: Porque aqui você adapta. O meu, até agora... Porque quando ela chegou aqui era como se ela estivesse vivendo num mundo de cegos (no meu ponto de vista), porque ela tentava se comunicar, mas ela não sabia se comunicar nem eu sabia como.

Mas, assim, mãe e filho, eles têm um laço que se entendem, e os outros lá fora? Como iam fazer para entender ela? Pelo menos agora ela já entende alguém na rua, de algum modo ela entende, porque ela chega em casa e me conta tudo e eu entendo ela. Então, aqui, nessa escola!

\footnotetext{
${ }^{53}$ Estava em processo de separação do marido.
} 
E prosseguiu a pergunta, tentando compreender um pouco mais o ensino ofertado a seu filho: Mas qual é o tipo de educação que tem aqui?

B: Aqui ela está se identificando com a Libras, que é a linguagem de todos os surdos, e tá agora desenvolvendo um pouco a fala, porque agora ela está escutando. Ela escuta mas não entende o que escuta, vamos supor, se alguém fala “"X,' isso é uma cadeira!", ela vai até repetir "cadeira”, mas ela não vai saber identificar o que é uma cadeira. Então, agora ela está aprendendo isso! Então, eu acho que aqui eles incentivam muito isso, não é como o INES que é só a Libras, só a linguagem deles. É tipo nós. A gente tem o nosso português, mas a gente quer aprender inglês, francês... Não quer aprender tudo isso? Aqui eles dão essa oportunidade. Acho que lá fora não é dada essa oportunidade para eles.

\section{Uma outra mãe quis compartilhar sua experiência também, disse:}

C: A minha experiência é um pouco diferente. Quando eu tive a notícia que meu filho "Y" era surdo, eu já estava um pouco preparada. Porque três anos antes de eu ter o "Y", eu senti o toque de Deus de aprender Libras e fui para uma escola, para o INES, aprender Libras. Obedeci aquela ordem que eu recebi, que eu senti que foi Deus quem me tocou, fui aprender Libras. Quando meu filho nasceu, eu tomei um susto com ele, mas eu já estava um pouco preparada porque eu já sabia um pouco da linguagem. Agora, quanto a escola, a primeira opção, quando a pessoa fez o exame [de audiometria] para mim, ele já me indicou uma escola: "Você vai para o INES! Que é uma escola de surdos onde ele vai aprender a ler, a escrever, desenvolver.", eu: “Tudo bem!". Foi a primeira escola que eu encontrei. Eu já conhecia o INES porque eu já tinha feito aula de Libras lá, então encaminhei o "Y" para lá.

Mas, com o passar do tempo, eu percebi que aquela escola de Libras limitava muito o surdo. Era muita Libras e eu ficava preocupada: "Tudo bem, aqui ele vai aprender a ler, a escrever... Se comunicar! Mas o mundo não é de surdos! Ele precisa se comunicar com uma forma que eles lá fora, as pessoas, possam entender ele! Porque não adianta ele ser 'fera' na Libras, chegar na rua, vai pedir alguma coisa, a pessoa vai ficar olhando para ele: 'o que é?', perdidos!”. Então, eu fique na minha preocupação, não só da educação, de ele aprender a ler e escrever, mas também de ele se comunicar com o mundo. Foi quando as pessoas me informaram: "olha, tem uma escola na Gávea, muito boa! Lá eles têm Libras e têm também a oralização". Foi quando eu tirei o "Y" lá do INES para vir para cá, e eu percebi que aqui, essa escola, abraçou o surdo! Abraça o surdo! E eles aqui têm contato com os ouvintes, então para mim foi importante a comunicação. Não é só a leitura, não é só a escrita... A comunicação. Porque nossos filhos vão para o mundo, então ele precisa se virar sozinho, porque eles vão crescer, eles vão trabalhar, eles vão casar. Então eles precisam ter uma boa comunicação.

Então, para mim, essa escola foi boa neste sentido, porque ele tem o apoio da fono $^{54}$, então ele vai aprender a falar, ele tem a Libras também, a gente já dialoga em Libras. Então aqui ele começou a se desenvolver.

Já " $D$ ” diz que sua primeira preocupação não estava relacionada com a educação de sua filha. Explica:

\footnotetext{
${ }^{54}$ Leia-se, fonoaudióloga.
} 
D: Eu já não tive de imediato a preocupação com a educação. Eu tive a preocupação com o cuidado da saúde dela, como estou tendo até hoje. Minha filha quando nasceu, ela nasceu de seis meses, era do tamanho daquela bonequinha ali que está na mão dela. Desse tamanhozinho! Então, nós tivemos aqueles primeiros meses de cuidado com a saúde. Mais tarde é que foi pensado nisso: “como é que vai ser a educação?". Aí, também, nós também fomos para a educação escolar, fomos parar no INES, que foi indicação do profissional: "vai para o INES!". Mas havia porque ela que precisava do INES, por ser surda, ela não aceitava o INES. Não aceitou e não aceita, ela não conseguiu, ela só fazia chorar dentro da escola. E começou a ser alfabetizada, mas não teve eficácia na alfabetização.

Passou o tempo aí entrou no "modismo" da inclusão, "né"?! E eu falo modismo porque não é o que ocorre lá fora. Mas foi para a escola de inclusão, teve um amparo legal que foi o intérprete, o instrutor surdo, o auxílio da sala de recursos, mas até sermos encaminhados também para cá.

Mas estamos ainda há apenas três semanas aqui. E eu já noto uma diferença! Talvez seja o espaço físico, a diferença do espaço físico daqui para lá, porque é o único parâmetro que eu tenho, é a única comparação que eu tenho até agora. Mas eu também não posso... Ela ${ }^{55}$ tem uma experiência de mais tempo, ela pode dizer com toda segurança, eu não, eu estou falando por apenas essas três semanas e eu já observo muitas mudanças da aluna surda e também da filha surda.

Então, em princípio, a preocupação que eu tenho com a educação é: ela terá essa continuidade? Vai chegar aí a atender a necessidade dela na educação?

Esta primeira fase mostrou que diversas são as preocupações no que diz respeito à educação de uma criança surda. Ademais, muitas das preocupações das mães se relacionam ao desconhecimento de como lidar com o surdo, talvez por falta de orientação após a detecção da surdez, ou por falta de conhecimento prévio mesmo sobre o tema, visto que para muitos foi uma surpresa, até mesmo uma delas disse que não conhecia ninguém surdo. O quadro que se põe é a necessidade de esclarecimento.

A segunda pergunta, mais direcionada a educação em específico, foi:

\section{Qual a maior dificuldade que você encontra com relação a educação do}

\section{seu filho?}

$\mathrm{E}$ " $\mathrm{D}$ ” iniciou as respostas dizendo:

D: Dificuldade? A dificuldade acho que é o tempo que eles [os surdos] têm. Porque quando a gente faz "Não, não mexe aí, não!", é rápido! Você tem que ir lá perto pra dizer assim: "não, não pode mexer aí, não" e ele precisa entender o que é o "mexer". Se você fala "mexe isso aí!", "mexe a panela!", ele precisa entender o que é o "mexer", afinal. Então, a maior dificuldade que eu vejo é o tempo que ele têm para entender aquilo que se fala. E eu ouvi alguém dizendo - não sei se

\footnotetext{
${ }^{55}$ Outra mãe sujeito da pesquisa.
} 
isso está errado ou se acontece -, mas parece que a maioria precisa fazer a mesma série em dois anos, "né?!", em três anos.

\section{Acrescentou "B": "Muito mais!". E prosseguiu "D":}

D: Olha, isso é uma preocupação! Onde reside essa dificuldade? Será que é o profissional que está ali? Porque o mundo não espera! A gente até diz assim: O mundo lá fora é uma beleza! Por causa disso! O mundo não espera! Então, o que está acontecendo? A dificuldade é se ele olha, ele está percebendo... As pessoas falam que o surdo é muito pela imagem, "né"?! Então essa imagem tem que ser pronta! Essa imagem tem que ser precisa!

Então, essa é a dificuldade que eu estou vendo, e, evidentemente, não estou esquecendo que a minha filha também tem outras necessidades, não estou falando só do caso dela mesma, estou falando de um modo geral. Então, assim, como é que um surdo vai ficar dois anos para fazer a primeira série? Três anos para fazer a segunda? Tem Alguma coisa acontecendo! Então tem que olhar os dois lados, do surdo - que a família tem disposição, porque olha aqui, "né"?! -, a família e a escola. O que é que está acontecendo, o que é que está aí nesse espaço para poder acelerar o processo?

Porém, "E" apresentou outra dificuldade:

E: Para mim, eu acho, o português, o ensino. Ontem foi um dever de casa que era uma confusão no texto. Era ao contrário as coisas. E como é que a gente vai explicar para o surdo? É muito difícil!

Obervou "A": "Eu estou sofrendo isso em casa também.". E "E"

finalizou dizendo: "E a minha filha é quase oralizada. Mas é muito difícil, e a gente tem que fazer!".

Mas "C" apresentou ainda uma outra dificuldade:

C: A maior dificuldade que eu acho é encontrar um escola próxima da nossa casa, que dê uma assistência que você possa ficar tranquila. Não é só ter Libras! "Ah! Aqui tem Libras, tem um professor que..." A gente precisa ir lá conhecer!

\section{Acrescentou "D": “A dedicação dele!". Continuou "C":}

C: É... A estrutura. Porque muitas das vezes fala em inclusão e quando você chega lá o aluno está lá no canto, elas não interagem, muitas das vezes, com os coleguinhas, muitas das vezes o professor não domina Libras. A dificuldade é encontrar uma escola adequada para os nossos filhos próxima da nossa casa.

Advertiu "E”: "Que eles aprendam!”. Seguiu "C":

C: É, porque aqui, por exemplo, essa escola é longe para a gente. Tem pessoas aqui que saem [de casa] quatro horas da manhã! Então, é muita dificuldade! A gente vem porque a gente é mãe e a gente pensa no futuro dos nossos filhos! A gente faz sacrifício! Mas nisso a gente deixa de trabalhar... 
Acrescentou "F": "Se dedica!", complementou "C": "A gente se exclui, muitas vezes a gente se exclui!"; e "D”: "Para proteger ele!". Disse "C": "Exatamente! Então a maior dificuldade é encontrar escola que atenda os nossos filhos, a nossa necessidade, próxima de nossas casas". Observou ainda "E":

E: Lá perto da minha casa tem, só que para ela não vai adiantar, porque no futuro, num concurso público, ela não vai conseguir! E eu não quero o pouco para ela! Eu quero que ela aprenda! Vai ter a Libras naquele colégio, o França ${ }^{56}$, tem a Libras, mas eu não quero só a Libras, quero que ela entenda o trabalho! Que ela aprenda português! Aprenda! Aprenda!

Foi nesse momento que " $D$ " compartilhou a experiência vivida recentemente com sua filha, neste mesmo sentido. E disse:

D: Entendi... Ela falou aqui uma coisa que me lembrei agora, veio a mente... No trabalho ${ }^{57}$ dela estava escrito assim: "Reescreva as frases substituindo a imagem, o desenho, pelo nome", que era para tirar a figura e botar [a escrita], "né"?! Eu lembro que era assim: o carro; aí tinha "o" e o desenho do carro. Ela parou com o caderno assim, aí eu perguntei a ela o que era "reescreva", ela leu letra por letra ${ }^{58}$, mas depois que falei para ela: "o que é? Qual o sinal?", ela não sabia realmente o que é "reescreva". O que você está dizendo, eu acredito e "vou contigo": será que o professor tem tempo de dizer para o aluno o que é que significa aquela palavra? Será que ele esclarece o significado do enunciado? Porque quando o aluno sabe o enunciado, independente de ele ser surdo ou ouvinte, ele "vai embora"! Entendeu? Ali está escrito "silêncio", qualquer um que passe vai fazer o sinal porque sabe ler e sabe interpretar o que está ali.

"Realmente...", disse "A", admirada. Continuou:

D: Não é?! Então, está escrito, ele vai interpretar! Está fazendo uma leitura de mundo! Quando eu olhei para ela e falei "reescreva", e cobri a primeira sílaba, aí mostrei para ela "escreva", "escrever" [fazendo o sinal], "reescrever" é de novo [de novo], escrever de novo [fazendo os sinais]. Aí escrevi com ela a palavra, aí fiz para ela "de novo" [o sinal], escrevi ${ }^{59}$ a palavra e "de novo", aí ela escreveu. Começou! Ela não entendeu de imediato, mas ela começou a entender o que era o "reescreva".

Então, as vezes o enunciado também, lá em Língua Portuguesa, se complica um pouquinho por isso, porque não deu tempo de interpretar o que o enunciado estava pedindo, o que a questão estava pedindo.

Com isto, conclui-se que as maiores dificuldades encontradas na educação do surdo são de âmbito externo, escolas acessíveis e que estejam

\footnotetext{
${ }^{56}$ Escola pública.

${ }^{57}$ A tarefa de casa designada pelo professor à aluna.

${ }^{58}$ Está se referindo a datilologia, os sinais das letras, o alfabeto manual da Libras.

${ }^{59}$ Fazendo uso da datilologia.
} 
adequadas, preparadas, para receber o aluno surdo tendo em vista a especificidade de suas necessidades educacionais.

A terceira pergunta, com o intuito de averiguar qual o conhecimento que tinham sobre a importância deste direito dada pelo nosso ordenamento jurídico, foi: A Constituição Federal diz que a educação prestada deve promover o pleno desenvolvimento da pessoa, seu preparo para o exercício da cidadania e sua qualificação para o trabalho (art. $205 \mathrm{CF}$ ). Você percebe se na escola atual seu filho está se desenvolvendo como as demais crianças da idade dele?

E a primeira e imediata resposta foi:

E: A minha está desenvolvendo! Minha filha está desenvolvendo. Não está quanto um ouvinte, porque eles "pegam" muito mais rápido, mas ela está se desenvolvendo.

Mas destacou "F":

F: A minha também está desenvolvendo, não como um ouvinte, mas está desenvolvendo.

A minha chegou aqui com três anos de idade, agora está com seis. Está na fase da leitura, assim, porque tudo para o surdo é um pouco mais demorado, a maturidade deles demora um pouco mais a $\mathrm{Z}$ [filha] já tem dois anos que ela implantou... Porque as pessoas acham que quando implanta o problema vai acabar, que ele vai ouvir e vai entender tudo... Não. Tudo tem um processo. A Z hoje está um pouco já falando bastante coisa, mas a maturidade é mais demorada, tem um trabalho de fono... Hoje, esse ano, eu fui para o três, porque ela ficou três anos no Jardim, e esses três anos que ela ficou no Jardim ela teve um ganho muito bom! Vai entrar no Primeiro Ano e está indo, mas não é como um ouvinte... Eles têm a dificuldade... Português é muito difícil! Porque a gente tem que ser teatral para eles poderem entender. A gente tem que ser uma atriz, tem que fazer tipo uma peça de teatro para poder entender o que é que está escrito ali. E o trabalho é ótimo, assim, mas...

Reafirmando a pergunta: Mas ela está se desenvolvendo? Frisou "F":

“Está!”. E ainda relatou "G":

G: E é por isso que a prefeitura não fez esse teatro nas escolas para que eles possam aprender! Eles não sabem lidar com as crianças! Eu tiro por duas meninas que estavam em uma escola lá... É Abolição, C? É França ${ }^{60} .$.

Acrescentou "C": "A França não é uma boa escola, não, acho que é depois de Pilares...", e "G" continuou dizendo: "É... E elas mesmo

\footnotetext{
${ }^{60}$ Uma escola pública.
} 
mandavam, a professora mandou que elas fossem para o INES, e lá tem!

Diz que tem... Então, eles não sabem, ‘né’?!”.

"A", então, passa a relatar o que ela tem observado com relação ao

desenvolvimento de seu filho:

A: Meu filho amadureceu muito! A vinda dele para cá, para o INOSEL foi fundamental, foi muito importante para ele, para a família dele. Lógico que para ele em primeiro lugar! Ele chegou aqui uma criança que não tinha noção de nada, entendeu? Não entendia, não só na parte do estudo, como maturidade. Então, depois que ele veio para cá ele teve uma dificuldade para se adaptar, foi um sofrimento. Mas depois que esse sofrimento passou eu vi o quanto que ele amadureceu. E foi muito importante na vida dele! Hoje ele está com quinze anos e hoje eu vejo ele como um adolescente, assim, totalmente já consciente das coisas. Ele tem, sim, claro, uma certa dificuldade com a aprendizagem ainda, que a gente sabe da diferença de um surdo para um ouvinte. Mas eu tenho certeza que a tendência dele, com o passar do tempo, é melhorar! Entendeu? É melhorar! Porque, realmente, para o meu filho, esse colégio foi e está sendo muito importante na vida dele. Muito! E ele precisava de uma estrutura que hoje é o colégio onde ele se encontra.

Neste momento " $\mathrm{H}$ " relata toda sua experiência com seu filho, desde

a descoberta da surdez até encontrar a escola que considerasse ideal para

ele:

H: O meu chegou aqui com três anos. É igual você fez na primeira pergunta, a preocupação. Eu fiquei preocupada quando eu descobri, porque eu descobri com dois aninhos. Está entendendo? Eu descobri com dois anos que ele era surdo e eu fiquei preocupadíssima! Porque eu fiquei perdida! Porque era o meu primeiro, "né"?! E hoje ele vai fazer onze aninhos, tem dez anos. Então, eu fiquei preocupadíssima, eu falei: “o que é que eu vou fazer?", eu não sabia que eu tinha um surdo dentro de casa! Eu achava que ele ia falar! E eu estava esperando porque os médicos falam que são cinco anos, até cinco anos, a pediatra falava e: "ele vai falar" e nada! Não saía nada! Só que eu achava que era normal. Só que não era normal. Conforme foi passando, com dois aninhos descobri a surdez dele, porque meu irmão chamou ele cinco vezes e ele não escutou, e ele achou isso anormal. Aí, então, eu descobri. Aí você vê: com dois anos a gente descobre! Aí corri para a $\mathrm{ABBR}^{61}$, pensei que era na $\mathrm{ABBR}$, não era. Lá eles só "pegam" criança desde bebê, não pegam criança já grande, eu não sabia. Aí eles me encaminharam para cá, no INOSEL. Me deram um encaminhamento para cá. Descobri tudo, corri atrás de tudo que ele tinha direito e corro atrás até hoje!

Aí o que acontece: "estudar no INOSEL? Escola de que?" Aí cheguei aqui o professor fez psicologia, aqui eles acompanham com fono, ótimo! Muito bom! Corri atrás de aparelho. É um sufoco para usar aparelho, dá trabalho, mas não consegui implante, não consegui de jeito nenhum, então eu desisti de correr atrás de implante, resolvi colocar o aparelho nele. Mas, graças a Deus, ele está com dez anos, desenvolveu, e até hoje eu estou correndo atrás, mas ele está desenvolvendo! Aprendeu muito aqui! Aprende até hoje aqui! Eu não tenho o que

${ }^{61}$ Trabalho de reabilitação. 
falar... Só tenho dificuldade para eu ensinar ele, está entendendo? Eu tenho dificuldade com Libras para ensinar ele. Mas, graças a Deus, eu tenho três, os três estudam aqui, então um deles interpreta tudo, me ajuda! Me ajuda para eu poder ensinar a ele o dever.

Para mim está ótimo! É benção!

"I" apresenta uma outra dificuldade, os pais desenvolvem também papel fundamental na educação dos filhos, por isso esta mãe apresenta uma dificuldade que ela encontra e percebe também em outras mães:

I: E a nossa maior dificuldade também é a gente encontrar alguém que nos ensine a linguagem de sinal também. Porque ninguém sabe! Ninguém sabe! Qual é o profissional que está disponível para um monte de mãe de surdos? Ninguém! Cadê a importância?

Acrescenta “J”: "Lá em casa é um absurdo!”. E "I” segue dizendo:

I: Nós sabemos que nossos filhos são surdos, mas a gente quer aprender! Tem o INES, mas nem todo mundo tem a mesma oportunidade. Tem que ir lá todo ano para se inscrever, ninguém consegue! Eu já estou há três anos tentando e não consegui entrar para eu poder aprender, para poder ensinar melhor meu filho, mas eu não consegui e aí? Um curso de Libras é mega caro! Condições de pagar a gente não tem, aí a gente vai aprendendo um pouco com eles, com o que eles sabem. Mas não dá!

Distante do tema posto, ressalta "B": "Mas tinha aqui, as mães não vinham, aí é o que acontece: acaba. É um monte de mãe, aí o pessoal foi faltando, aí ficou eu e mais duas!’”.

"J" Coloca outra questão:

J: E os aparelhos, "né", que vocês falam, que gasta, só que eu tentei ver para o meu filho, o custo é muito alto! A gente ganha o que? Um salário! Fui ver para o meu filho, estava na faixa de seiscentos reais, e o delas que é implante? Por isso que eu não quero que faça implante, é muito mais caro. Ela falou para mim, quanto foi o seu?

\section{Responde "F": "Quinhentos e trinta reais". E continua "J":}

J: É... É muito gasto com ela, por isso que eu não quero que meu filho use implante, não quero! É um absurdo! As vezes eu fico chorando, porque as vezes eu passo vergonha. Meu filho uma vez estava gritando dentro do ônibus, aí, na época ele não falava nada, a moça mandou: "cala a boca! Manda esse garoto calar a boca!", porque ele estava gritando dentro do ônibus, aí eu fiquei quieta, não vou discutir. Mas o povo não quer saber, não! Que a criança que é surda... Não quer saber, não. Aí manda calar a boca.

Lá em casa, meu pai não tem estrutura nenhuma. Eu tenho um irmão que é doente, ele chama de maluco... Aí eu fico pensando que eu tenho que ajudar ele para o futuro dele. 
Eu fico chorando as vezes, abraço as minhas filhas para me ajudarem. Ele bota o som da televisão bem alta, aí a outra: "que isso! Ele é surdo?", "Você não sabe que ele não consegue escutar? Para de palhaçada!". As meninas lá em casa, as irmãs, não conseguem aceitar isso.

E mais uma vez reconhecendo o importante papel desenvolvido pela família, diz "A":

A: A vida é muito corrida, a gente fica procurando tempo para tudo, mas eu passei por isso também, entendeu? E ainda passo, não só passei, ainda passo, porque o "W" ainda tem dificuldades em casa. Eu tenho dois deficientes auditivos, tenho dois implantados, e hoje a minha maior dificuldade é do ensino em casa e eu peço para o meu filho mais velho, que tem dezoito anos, para colaborar, para sentar um pouquinho com ele. Já pedi muito. Hoje eu parei um pouco até mesmo porque eu entendi que no caso do meu filho ele também tem uma cabeça muito cheia, muita coisa, muita cobrança em cima. Hoje eu estou mais consciente disso.

Mas, realmente, quando a família, que é o mais importante dentro de casa, entende, procura entender, as coisas andam melhor. Mas, infelizmente, nem mesmo dentro de casa é o primeiro lugar que acontece isso, de você entender que meu irmão, ou o meu filho, ele é surdo, ele precisa da minha atenção, eu vou buscar um tempinho para ele. Mas, infelizmente, nem sempre acontece isso.

Destaque-se que nesta fase, muitas mães dizem que seus filhos estão se desenvolvendo, mas comparam com ouvintes dizendo que estão se desenvolvendo, porém não como ouvintes. A surdez não representa um impedimento intelectual, desta forma, apenas a surdez não representa uma barreira ao desenvolvimento da criança surda como o de qualquer outra criança. Ela pode se desenvolver da mesma forma que um ouvinte, como comparado pelas mães, se ela não se desenvolve da mesma forma é evidência de um ambiente despreparado ou insuficiente, que não propicia seu desenvolvimento. O que pode ser resultado do despreparo dos pais e/ou do ambiente escolar.

A quarta pergunta, com o intuito de compreender qual o nível de conhecimento das mães a respeito dos limites do direito à educação no que diz respeito a pessoa surda, foi realizada da seguinte forma: Você sabia que existe uma Lei que possibilita a existência de escolas públicas bilíngues (Libras/PT)?

Não hesitou em dizer "L": "Isso aí é só no papel, porque na prática...", e em seguida "D": "Na prática não existe isso!". E seguiu "L": 
L: Isso é só no papel, porque na prática isso aí não existe! Eu tenho conversado com pessoas que têm crianças em colégio público, surdos, que já foram ao colégio assim de supetão, viram a criança lá atrás da sala e isso quando o professor não pede para tirar a criança que a criança está atrapalhando a sala de aula!

Observou "A": "Isso é uma pura ignorância! Com certeza! E preconceito! Eu vejo...", enquanto "L” prosseguia dizendo: “Aí depois quando a mãe tira [do colégio], aí vai para o Conselho Tutelar! Porque não botou para o colégio. Vai para o colégio para quê? Se pode ficar lá no fundo..."; "Desprezado!", acrescentou "A". "Aí fica em casa... Fica em casa! Pelo menos em casa está brincando com a mãe, com os irmãos...", continuou "L". "É uma falta de compreensão que tem que colocar aquele aluno na frente por ele ter uma necessidade maior.", disse "A".

Neste momento "L" contou uma experiência que chocou a todos:

L: E isso não é nem só a surdez, outras deficiências também! Porque a criança as vezes precisa estar na sala de aula e precisa também de uma pessoa ali para estar ajudando. E teve um caso também de uma vez que uma menina falou que trabalhava num colégio público, ela falou assim: "Cansei de ficar com criança dentro da cozinha!", porque a professora estava falando que ele estava atrapalhando na sala de aula! Dentro da cozinha!

“Um absurdo! Ao invés de aprender... É um absurdo!”, disse “A”. "E a mãe que sai mais cedo para trabalhar?", destacou "J". "Está difícil...", lamentou "A".

"M" já havia passado por isso com seu filho e compartilhou conosco:

M: Isso aí que ela está falando é verdade mesmo! Isso já aconteceu com o meu filho na creche! E foi uma luta porque para arrumar uma pessoa para entender ele... Porque eu já fui saber já... Depois que descobri... Foi ela que descobriu que meu filho era surdo... Depois que descobriu que o "K" era surdo, aí ela pegou e falou: "M, vamos correr atrás porque o "K" não escuta.", eu falei "o que é isso?", "É... Ele não escuta...". Aí eu botei ele na creche. Tinha momento que meu filho estava na cozinha! Meu filho já ficou de cozinha, junto com a cozinheira! Porque disse que ele tava gritando muito!

Com sentimento de impotência diante de tais relatou, questionou "B": "Porque é tipo assim, Barbara, tem essa Lei, mas o que fazer para que essa Lei seja cumprida?”. E completou “L”: “Se essa Lei valesse a gente 
não teria que vir para cá... Porque eu acordo quatro e meia da manhã todos os dias!".

Disse mais "J": "Só tem essa escola, o INES, e aqui, o INOSEL". Porém, relatou "B":

B: Até tem escolas com pessoas assim... Com intérprete, onde está a filha da "P", lá na Freguesia e onde está a filha da "Q". Ela falou que a filha dela [da "Q"] aqui, por exemplo, a filha dela não se identificou com essa escola. Nem tudo é igual. Aqui ela não se identificou. Aqui ela ficava só na sala de recursos, não botavam ela para fazer prova... Hoje ela faz prova, a menina tá bem mais desenvolvida... Na escola pública com inclusão. $\quad$ Eu não fui lá ainda para eu ver, mas me passou isso. Ela é mãe da menina, ela sabe. É ela quem está com a menina!

Eu só não sei o nome da escola... Não sei se é Edgar Werneck... Só sei que fica na Freguesia! Sei que essa escola funciona. Sei que é uma escola pública. Eu sei que fica na Freguesia. Eu sei que é uma escola muito bem dessas intérpretes que tem lá e essas próprias intérpretes tem um dia lá com negócio de sala de recursos que elas que dão para os meninos, são muito atenciosas. Até elas já pediram para eu tirar os meninos daqui... Eu não me vejo tirar a "X" daqui por enquanto. Porque, eu acho assim, a dela já saiu totalmente... Saiu daqui sem saber nada. A "X" já aprendeu Libras aqui e está aprendendo porque ela não sabe o suficiente, não sabe ainda tudo, pela quantidade de tempo que ela está aqui (ela está aqui desde 2008), entendeu? Ela sabe falar a Libras do jeito dela aí... Mas não sabe ainda totalmente perfeito que nem deveria já saber. Mas está se desenvolvendo. Eu não vou tirar ela daqui para eu colocar do outro lado.

A filha [da "P"] saiu daqui ela já sabia ler, sabia Libras, tudo direitinho. A outra não, aprendeu lá. E, pelo menos elas, falam que lá é maravilhoso! Eu ainda não tirei nenhum dia para ir lá para eu ver. Mas elas com os filhos lá elas sabem, "né"?!

\section{Discorreu "L":}

L: É que nem eu sempre falo: o surdo não é como o ouvinte. Vamos supor: uma criança ouvinte repetir a mesma série duas vezes, tudo bem, isso aí é ruim. Mas para um surdo é normal, porque o surdo tem mais dificuldade. Repetir duas vezes é normal! É como se fosse um ouvinte que passa, mas fica de recuperação, é um surdo repetindo uma série duas vezes. Eu acho assim! Porque eles tem dificuldade. Tem muita dificuldade!

\section{E um impasse se pôs:}

B: Aqui era obrigatório o surdo repetir a mesma série duas vezes. Foi falado isso aqui.

L: Obrigatório?

B: Agora que não é mais por causa de uma Lei aí, por causa da idade.

L: Então, vamos supor que a minha filha faça uma prova, ela tem condição de passar. Aí não é obrigatório! Porque obrigatório é assim: ela tem condição de passar, mas não vai porque é obrigatório. Então, não é obrigatório, está entendendo? É porque eles precisam! Eles têm dificuldade, não conseguem passar. 
Esta foi a conclusão de "L" quando então "B" disse:

B: Tanto que eu já pedi para a "X" repetir, eles não quiseram, uma vez. Pela idade. Eu falei: "então vai passar ela por passar, porque ela não sabe!". Eu mesmo já estou aqui já tem oito anos, gente! Vai fazer oito anos agora em maio que a "X" está aqui. Primeira série ela repetiu, eles falaram assim: "olha, ela não tem capacidade de passar. Você está de acordo?", eu disse "sim". Você acha que eu vou querer que minha filha passe para o quinto, o sexto, sem saber de nada? Eu prefiro que ela repita mais um ano, do que ela passar sem nenhum entendimento! Essa é a dificuldade deles. A gente não pode deixar. Eu prefiro que repita para poder aprender!

"D" demonstrou conhecer a pertinência legal do tema. Pediu a palavra e disse:

D: Existe, sim. Existe. Existem duas. Mas uma, assim, na rede pública, vai até quinto ou sexto ano. Para ali e o profissional não vai mais adiante. Agora falou que é a questão da idade da Lei.

\section{Outras mães relataram:}

I: Eu não sabia!

G: Eu não sabia!

E continuou "D":

D: Eu sei! Inclusive diz que se tiver um aluno surdo, esse aluno, esse único aluno, ele tem direito a um intérprete! Independente da série em que ele esteja! Eu fui atrás de levar minha filha para médico, o cuidado de chegar até aqui, eu fui à nona CRE, eu fui à Secretaria, eu enviei e-mail, para saber onde estava o intérprete. Fui até na escola - e ela como lembrou a questão da idade - a nossa autoridade política, o prefeito do Rio de Janeiro, ele disse o quê? Que ele não podia... Não ia enviar intérprete para lá, porque tinha que esperar um pouco. Aí eu falei para ele: "e vai fazer o que nesse tempo, nesse período?", porque eu falei: se eu pegar seu celular, se eu sentar aqui agora, peguei escondido, você vai chamar a polícia, não vai? Você vai fazer cumprir a Lei. Porque é seu, não é?! "Chama a polícia! Prende! Porque ela roubou meu celular!". Mesmo sabendo que a escola precisa de um intérprete... Um aluno surdo, diz a Lei! E não está acontecendo!

Aí mandou minha filha para a noite, por causa da idade, - esse ano ela completa dezessete anos no final do ano - não tinha intérprete e nem terá. Até agosto não terá intérprete. E todos os intérpretes estão em casa sentadinhos, as mulheres fazendo unha, os homens cortando o pezinho do cabelo. Não querem estar trabalhando, entendeu? Porque... É, não tem intérprete trabalhando! Não porque não queira trabalhar... Porque não pode ir. Porque eles não podem cumprir o que diz a Lei! Eles querem trabalhar, eles querem estar em sala de aula, e não estão! Eles estão também igual a todo mundo, não pagam contas, porque não está acontecendo! Quem é que faz cumprir a Lei nesse caso? Eu perguntei! Falei: "olha só, mesmo fazendo a denúncia? Não vem ninguém para fazer cumprir? Ele é um cidadão também! Onde está a cidadania?”. Não obtive resposta. Então, se a 
minha filha é surda, é aluna, está inscrita! Regularmente! Cadê o intérprete da minha filha? Aí disseram assim: "Ah, a senhora tem que procurar", eu falei: "trago aqui uma relação.", aí pedi um intérprete, mas não pôde ficar, porque ele não ia ser contratado.

Quem é que vai cumprir a Lei? Quem é que faz cumprir?

Lamentou "A": "Ninguém!".

Seguindo, disse "D": "A Lei existe e ela é bem clara: o aluno surdo tem direito a um intérprete, sim! Desde que seja um aluno só, somente um! Precisa ter um intérprete.", e mais uma vez "A": "Se o direito fosse cumprido, nossos filhos surdos não estariam enfrentando tanta dificuldade".

Diante disto, vê-se que não apenas as Leis referentes ao tema são desconhecidas como a inefetividade delas, a ausência do tratamento adequado, fez com que muitas crianças e seus responsáveis fossem submetidos a condições degradantes, como relatam as mães que tiveram seus filhos retirados da sala, dentre outras situações constrangedoras. A sensação de impotência também é clara, se perguntam como fazer cumprir a Lei.

A quinta questão posta para discussão, com relação a real acessibilidade a uma escola que acolha surdos: Você considera fácil encontrar uma escola bilíngue (Libras/PT) acessível (tanto na questão de localidade quanto financeira)?

Todas disseram neste momento: "Não!". E ainda acrescentou "A": “É quase impossível!".

Destacou "N": "Se fosse fácil eu não estaria aqui. Eu venho de Nova Iguaçu.", e seguida por outras mães:

L: É... Nem eu!

J: Nem pagando...

Disse mais "H” sobre a condição das mães que ali se encontravam:

H: É difícil... E a maioria aqui mora tudo longe! Uma é Nova Iguaçu, outra é Santa Cruz... As únicas que moram perto sou eu e elas três, a maioria mora tudo longe. Nós moramos na Rocinha. Tudo longe... Então não é fácil! É muito difícil para elas! Moram longe, a maioria! Imagina, sair quatro horas da manhã com uma criança, do jeito que está difícil e violento! Não é verdade? Não está violenta a cidade? Está violento mesmo! E elas saem quatro e pouca da manhã? E ainda 
também está passando pelo perigo. Elas sabem quatro e pouca. Imagina! É difícil! É difícil, não é fácil, não! É muito difícil!

Neste ponto, resta demonstrada a dificuldade encontrada para encontrar um escola dentro dos padrões de efetividade já reconhecidos legalmente os quais correspondem também ao direito constitucional em foco.

E, tendo em vista que a educação não é tarefa exclusiva do Estado, conforme aduz o dispositivo constitucional, e ao mesmo tempo com o intuito de ressaltar a importância que uma escola com qualidade de ensino tem na vida da pessoa e de seus familiares, foi questionado: Você tem conhecimento de Libras? Se sim, a utiliza em casa com seu filho?

Muitas se absteram neste momento, porém, logo disse "N": "Não muito.". E logo outras: "A": "Eu tenho"; "B": "O pouco que eu tenho eu uso."; e "E”: "Eu também.”. E continuou “A":

\begin{abstract}
A: O pouco que eu aprendi, eu também uso. Eu comecei a aprender, mas eu parei, porque quando eu ia deixar ele eu ficava, mas o professor falou para mim que eu não podia ficar, que eu não poderia participar da aula com meu filho, acompanhando. Aí eu falei para ele: "mas e agora? Como eu vou fazer para fazer a aula de Libras?". Aí ele fez assim [expressão como quem diz: não sei]. Aí eu falei: então não posso mais frequentar e pronto, acabou.
\end{abstract}

Enfim, constata-se que pouco é o conhecimento de Libras da maioria das mães o que dificulta a comunicação da criança e torna ainda mais importante a participação da escola.

Com esta pesquisa, conclui-se que ainda existem muitas dificuldades em encontrar uma instituição de ensino que de fato eduque surdos. Essa foi a experiência destas mães, porém refletem a maioria dos casos. Foram 14 mães e nenhuma delas teve por completo uma boa experiência com a educação escolar de seus filhos.

Por outro lado, vê-se o esforço destas em promover o melhor ensino aos seus filhos, mesmo que lhes custe abrir mão de si.

A educação efetiva é proveniente de uma articulação entre Estado, família e sociedade civil, o desenvolvimento da potencialidade do indivíduo 
é a última esfera a se realizar, e seu desempenho vai depender de como as demais de estabelecem.

O ordenamento jurídico nos dá base para uma educação efetiva, e sua inefetividade gera efeitos reversos e, por conseguinte, a restrição de direitos fundamentais dos educandos. 


\title{
6. A IMPORTÂNCIA DA ESCOLA BILÍNGUE NA EFETIVIDADE DO DIREITO À EDUCAÇÃO DA PESSOA SURDA
}

\author{
"Quantas vezes eu pedi uma Escola de Surdos e \\ você achou melhor uma escola de ouvintes. \\ Várias vezes eu sinalizei as minhas necessidades e \\ você as ignorou, colocando as suas ideias no lugar. \\ [...] \\ Ser Surdo de Direito é ser "ouvido”... \\ é quando levanto a minha mão e \\ você me permite mostrar o melhor caminho \\ dentro de minhas necessidades. \\ [...] \\ No meu direito de escolha, \\ pulsa dentro de mim:
}

Vida, Língua, Educação, Cultura e um Direito de ser Surdo."

(Lamento Oculto de um Surdo; Shirley Vilhalva)

Para compreender qual a relação de um modelo educacional específico com o direito à educação em si é salutar que iniciemos pela compreensão de "efetividade" no âmbito jurídico, cuja ocorrência se dá na união indissociável de dois pressupostos: a eficácia jurídica e a eficácia social.

E, uma vez que a "efetividade seria a combinação da eficácia jurídica - a norma está apta a incidir -, conjuntamente a eficácia social; leia-se, a aptidão formal da norma para ser aplicada somada com a adesão dos destinatários da norma" (Ramos, 2013, p. 01), ou seja, a perfeição da norma para ser aplicada somada a adesão dos destinatários à norma, o desejo de que ela funcione; cabe distinguir a conceituação destes dois aspectos.

A eficácia jurídica da norma legal consiste na "lei perfeita", aquela que reúne todos os pressupostos de validade e então dotada de capacidade para influir no ordenamento jurídico e, por conseguinte, na esfera jurídica de seus destinatários, conforme leciona Luiz Roberto Barroso: 
"A eficácia dos atos jurídicos consiste na sua aptidão para a produção de efeitos, para a irradiação das conseqüências que lhe são próprias. Eficaz é o ato idôneo para atingir a finalidade para a qual foi gerado. Tratando-se de norma, a eficácia jurídica designa a qualidade de produzir, em maior ou menor grau, os seus efeitos típicos, 'ao regular, desde logo, as situações, relações e comportamentos nela indicados; nesse sentido, a eficácia diz respeito à aplicabilidade, exigibilidade ou executoriedade da norma' (Silva, J. A., 1982, p. 56).” (Barroso, 2009, p. 81)

E a eficácia social "é a concretização do comando normativo, sua força operativa no mundo dos fatos" (Barroso, 2009, p. 82), advém de sua adequação à realidade social, gerando nos destinatários da norma um sentimentos de representação e cumprimento espontâneo da norma, fazendo com que os casos de insubordinação sejam ínfimos numericamente falando, em comparação aos casos de obediência à norma.

Bem conclui Barroso sobre o conceito de efetividade:

"A efetividade significa, portanto, a realização do Direito, o desempenho concreto de sua função social. Ela representa a materialização, no mundo dos fatos, dos preceitos legais e simboliza a aproximação, tão íntima quanto possível, entre o dever-ser normativo e o ser da realidade social.” (Ibid., p. 82)

À vista disso, é cediço que mais importância para a efetividade de uma norma tem a sua eficácia social do que jurídica (sem detrimento desta), pois é a eficácia social que assegura real aplicabilidade, que oferece do próprio destinatário o mecanismo para a verdadeira aplicação da norma, garantindo assim, sua efetividade, do contrário seriam necessários meios de coação para impor seu cumprimento forçoso.

Bem assim, a efetividade do direito à educação se dará na união de sua eficácia jurídica mais a eficácia social. Quanto à sua eficácia jurídica, isto é fato, há norma constitucional que o testifica, e não apenas, mas sendo norma constitucional se sobrepõe a qualquer outra regra do ordenamento jurídico, este deve estar adequado a ela. Portanto, não diferente das demais normas, estas também, por si só, são dotadas de imperatividade, ainda que sua eficácia social não tenha sido alcançada.

“A Constituição, [...], é um sistema de normas jurídicas. Ela institui o Estado, organiza o exercício do poder político, define os direitos fundamentais das pessoas e traça os fins públicos a serem alcançados. [...] É constitucional toda e qualquer norma inscrita em uma Constituição rígida, que, dotada de supremacia, 
situa-se no vértice do ordenamento jurídico, servindo de fundamento de validade de todas as demais normas.

As normas constitucionais, como espécie do gênero normas jurídicas, conservam os atributos essenciais destas, dentre os quais a imperatividade. De regra, como qualquer outra norma, elas contêm um mandamento, uma prescrição, uma ordem, como força jurídica e não apenas moral. Logo, a sua inobservância há de deflagrar um mecanismo próprio de coação, de cumprimento forçado, apto a garantir-lhe a imperatividade, inclusive estabelecimento das conseqüências da insubmissão ao seu comando. As disposições constitucionais são não apenas normas jurídicas, como têm um caráter hierarquicamente superior, não obstante a paradoxal equivocidade que longamente campeou nesta matéria, considerando-as prescrições desprovidas de sanção, mero ideário não jurídico.” (Ibid., p. 75, 76)

As formas de cumprimento compulsório das determinações constitucionais garantem que esta não seja real apenas num mundo ideal, contudo, da mesma forma, na vida prática. A eficácia social é que assegura de fato sua efetividade, pois significa que a norma está correspondendo ao clamor social, realmente representando o que a sociedade espera desta.

O direito é aquilo que pertence, que faz parte da esfera jurídica de seu possuidor e precisa do material para realizar-se. Assim, a efetividade dependerá de políticas públicas para concretizar este direito social, e a tutela judicial tem notável valor para tal, para que seja reconhecida a imperatividade $^{62}$ da norma que assegura o direito, fazendo valer o Direito e a justiça na realização da dignidade humana.

E de maneira nenhuma haverá ingerência ${ }^{63}$ de um poder estatal sobre outro, porquanto se tem bem definido que a composição de normas a respeito do exercício dos direitos sociais é integrante das atividades do Poder Legislativo; a tutela da efetivação dessas normas, por meio de mecanismos próprios, é de responsabilidade do Poder Judiciário; e a formulação de políticas públicas aptas a favorecer o acesso de toda a

\footnotetext{
${ }^{62}$ Quanto a isto, é proveitoso e muito nos acrescenta as palavras do Ministro Barroso: "As normas jurídicas, quer se destinem a organizar o desempenho de alguma função estatal (normas de organização), quer tenham por fim disciplinar a conduta dos indivíduos (normas de comportamento), revestem-se de uma característica que é própria ao Direito: a imperatividade.” (Barroso, 2009, p. 74). Logo, não importa o caráter da norma, a imperatividade é seu aspecto inerente.

${ }^{63}$ É patente que o Poder Judiciário não poderá atravessar atos estatais sob os juízos de conveniência e oportunidade, atos exclusivamente políticos (atos que não afetam direitos subjetivos) os quais impossíveis de prestação jurisdicional, contudo, mesmo estes não devem ser atos completamente arbitrários e assim se justifica o controle mútuo entre os Poderes do Estado (Barroso, 2009, p. 85).
} 
população a esses direitos são da esfera do Poder Executivo. E todas as esferas devem estar alinhadas à serviço da população, e em observância ao art. $5^{\circ}, \S 1^{\circ}$, da CRFB que elucida que "as normas definidoras dos direitos e garantias fundamentais têm aplicação imediata”.

Como salienta o Ministro Barroso, "o Direito existe para realizar-se. O Direito Constitucional não foge a este desígnio. [...], não pode existir uma norma ulterior, de grau superior, que a proteja. Por conseguinte ela deve encontrar em si mesma a própria tutela e garantia" (Barroso, 2009, p. 84).

Portanto, quando a Constituição Federal certifica que a educação deve ser prestada visando o pleno desenvolvimento da pessoa (art. 205, da CRFB/88), para que o direito à educação seja efetivo além da norma jurídica dotada de imperatividade (já existente, a norma constitucional), fazse necessário a correspondência com a realidade social para que de fato a educação promova o pleno desenvolvimento do indivíduo a quem a norma se destina.

A realidade da pessoa surda é que são uma minoria linguística e cultural, desta forma, a educação promovida sem que seja adequada a este fato, sem que sejam observadas suas necessidades, produzirá analfabetos funcionais ${ }^{64}$ ao invés de pessoas em pleno desenvolvimento, tornando em mera utopia uma educação básica de qualidade.

Proveitosa para esta discussão se faz a menção da Declaração Universal dos Direitos Linguísticos de 1996, que embora não integre o ordenamento jurídico brasileiro, foi desenvolvida pela UNESCO, organização universal na qual há representação brasileira. Bastam dois artigos:

\footnotetext{
${ }^{64}$ Sobre isto relata a Dra. Sueli Fernandes:

"A formação da consciência de aprendizes surdos demanda mais que a mera experiência visual com o objeto de conhecimento, demanda a internalização de signos que tenham uma encarnação material compartilhada em seus usos e funções sociais.

Dito de outra forma, a mera percepção visual direta da escrita, sem a mediação de um adulto mais experiente que a domine como complexo instrumento cultural possibilita apenas a consciência mecânica de seus elementos externos: o desenho de letras e palavras. [...]

Nesse sentido, a Língua de Sinais exerce não apenas a mera função instrumental de recurso para a leitura do Português escrito, mas, sobretudo, de língua que mobilizará as hipóteses dos alunos sobre a constituição de sentidos do texto.” (Fernandes, 2012, p. 40)

Ou seja, uma educação que não observa o contexto do aluno, não educa verdadeiramente.
} 
"Sección II - Educación

Artículo 23

[...]

3. La educación debe estar siempre al servicio de la diversidad lingüística y cultural, y las relaciones armoniosas entre diferentes comunidades lingüísticas de todo el mundo. [...]

Artículo 26

Toda comunidad lingüística tiene derecho a una educación que permita a todos sus miembros adquirir el pleno dominio de su propia lengua, con las diversas capacidades relativas a todos los ámbitos de uso habituales, así como el mejor dominio posible de cualquier otra lengua que deseen conocer." (UNESCO, 1996)

A língua materna é a melhor maneira de autoexpressão do surdo, de autoestima, de autoconhecimento, bem como para qualquer outra minoria linguística inserida num contexto na qual a língua majoritária não é sua língua materna, não é a toa que se observou a necessidade de uma declaração universal que versasse sobre a importância de respeito à diversidade linguística. Mesmo que não fale especificamente da pessoa surda, como minoria linguística e cultural, pode se aplica a estes.

Os artigos destacados ressaltam a demanda por uma educação que valorize a diversidade linguística e cultural numa relação harmoniosa entre a língua majoritária e a língua minoritária, além do direito de toda comunidade linguística, independente de ser majoritária ou minoritária, toda comunidade linguística, de adquirir pleno domínio de sua própria língua, numa forma de estímulo de suas capacidades, inclusive servindo de meios para aquisição de outros conhecimentos, até mesmo da língua majoritária.

Sobre isto trata Tanya Amara Felipe:

"A partir dessas reflexões sobre a língua, pode-se dizer que as comunidades
surdas brasileiras e em outros países, que se autocaracterizam enquanto
comunidades surdas, são grupos com identidade cultural, partilham de crenças e
valores comuns e, em seu modis vivendis, sua língua preferencial, enquanto
patrimônio histórico-social, está em uma situação diglóssica, sendo considerada
uma língua de uma minoria linguística, de menor prestígio e o português, no caso
do Brasil, lhes é imposto como língua majoritária." (Felipe, 2012, p. 9)

Relata ainda a autora que por "questões educacionais, socioeconômicas, psicológicas, e político ideológicas" (Ibid., p. 9) muitos surdos em fase escolar estão sendo de certa forma privados da língua 
portuguesa e da língua de sinais, acarretando no conhecimento insuficiente de ambas as línguas, o que influi diretamente no malogro escolar e, por diversas vezes, evasão da instituição de ensino.

Acontece que o modelo comumente adotado pelas escolas é o de educação "inclusiva" que insere o aluno surdo, ou uma pequena quantidade de alunos surdos, numa classe de ouvintes com a proposta do ensino e utilização apenas da língua majoritária, no caso, o português, e nem os educadores nem os alunos ouvintes utilizam a língua minoritária, no caso a língua de sinais, a não ser no caso de grande incompreensão do aluno, aí se utiliza a língua de sinais.

Outras escolas trabalham com a Libras apenas na educação infantil, como meio de ministrar a língua portuguesa e demais conhecimentos, para que aos poucos se deixe de utilizar a língua de sinais.

O resultado destes modelos é um conhecimento incipiente em uma e outra línguas; isolamento na sala de aula, devido à divergência na comunicação; carência na autoconfiança, prejudicando ainda seu desempenho escolar; além da possibilidade de abandono, evasão, escolar posteriormente.

Aparentemente a determinação legal de Atendimento Educacional Especializado proporciona o melhor mecanismo de educação de surdos, no entanto, a prática tem se mostrado diferente disto. A professora Tanya A. Felipe nos esclarece o que tem ocorrido no modelo educacional atual:

\footnotetext{
"A política inclusiva brasileira, criou um Atendimento Educacional Especializado - AEE, em salas multifuncionais que, funcionando diariamente em teoria mas não na prática, em contra turno para todos os 'alunos com deficiência', incluem em seus documentos orientadores para o AEE dos 'alunos com deficiência auditiva', disponibilizados no site do Ministério da Educação (FELIPE, 2012), entre as atividades as serem trabalhadas, o Atendimento Educacional Especializado para o ensino de Libras, cujo conteúdo tem se resumido à criação de sinais para as disciplinas específicas, embora, por decreto, deveria ser ensino da Libras como L1 ${ }^{65}$ em todas as séries da Educação Básica”. (Ibid., p. 20)

E prossegue a autora:
}

\footnotetext{
${ }^{65}$ Leia-se, primeira língua.
} 
"Devido a esse apartheid linguístico, em que a Libras é apenas utilizada no AEE, devido ao despreparo da maioria dos professores, à ausência de intérprete e ao trabalho inadequado para ensino-aprendizagem tanto da Libras como do português, essa política inclusiva para os surdos tornou-se uma proposta de educação bilíngue transitória e, devido também às condições inadequadas em sala de aula inclusiva, professores e alunos ouvintes sem domínio da Libras, material didático-pedagógico específico para ouvintes, entre outros fatores de ordem psicológica e socioeconômicas, esses alunos surdos têm ficado prejudicados em seu desenvolvimento linguístico em sua língua preferencial e patrimonial ${ }^{66}$, não conseguindo uma competência linguística satisfatória em nenhuma das duas línguas, o que tem prejudicado também seu rendimento escolar. Portanto, essa educação bilíngue transitória não está conseguindo nem atingir seu objetivo que seria o monolinguismos na língua majoritária." (Ibid., p. 20)

Por outro lado, a instituição de ensino que se objetiva ao "fortalecimento e formação de identidade dos alunos de minorias linguísticas" (Ibid., p. 15) desenvolvendo suas línguas juntamente com a língua majoritária, levando a interação de alunos que utilizam uma e outra língua é o modelo educacional exemplar, o qual se aspira.

O modelo de pleno bilinguismo assegura a utilização da língua minoritária aos alunos que a têm como primeira língua, a qual servirá também como língua de instrução. Podendo haver uma imersão completa na segunda língua, no caso, a língua portuguesa na modalidade escrita, desde a educação infantil ou gradual ao longo dos demais anos de escolaridade.

Isto possibilita que os professores ${ }^{67}$ em ambas as classes trabalhem com uma proposta curricular no mesmo nível e aos alunos, os encoraja, investe no progresso das suas habilidades e fomenta sua integração com os demais e a sociedade, valorizando o respeito às diferenças socioculturais e linguísticas, visto que a língua majoritária não será descartada, mas será

\footnotetext{
${ }^{66}$ Leia-se, língua majoritária.

${ }^{67}$ Em muito contribui salientar o papel imprescindível que exerce o profissional da educação, conforme fala das professoras Kelmam e Buzar: "É de extrema importância a presença do professor de Libras em uma educação que se autodenomine bilíngue, pois além de ser o responsável pela construção desse conhecimento com os alunos da escola (surdos e ouvintes), contribui decisivamente para a aprendizagem desta língua pelos demais participantes da comunidade escolar, permitindo que uma política de acessibilidade linguística digna e eficaz perpasse todo o contexto, em prol do reconhecimento e valorização do outro. Porém, o mais importante, é que este profissional funcione como peça fundamental na construção da identidade surda pelas crianças surdas" (Kelman \& Buzar, 2012, p. 12). O educador será quem lidará diretamente com o aluno surdo, ele precisa estar municiado dos aparatos necessários, como o conhecimento da língua, bem como ter em mente a função essencial ao desenvolvimento do aluno que a utilização de sua língua materna exerce, sem constituir espaços para a exclusão de nenhum aluno.
} 
ministrada como segunda língua, na modalidade escrita ${ }^{68}$, e a modalidade oral da língua deve ser opcional.

Fato é que a família assume papel fundamental na educação, isto não foi descartado no texto constitucional e deve-se destacar isto, porém ocorre que muitos surdos nascem em contexto familiar de ouvintes, que muitas vezes não sabem a forma correta como lidar com a educação de seu filho surdo. Conforme nos esclarece Tanya A. Felipe:

\begin{abstract}
"Devido à maioria dos surdos não serem filhos de pais surdos e devido ao desprestígio da Língua Brasileira de Sinais - Libras, por um período longo da história da educação dos surdos, eles não adquirem a Libras como primeira língua e sua identidade cultural acontece geralmente tardiamente; além disso, a maioria desses surdos adquire apenas uma competência linguística conversacional do Português, ou seja, a compreensão dessa língua depende de apoio contextualizado e eles ficam em desvantagem no sistema educacional regular que utiliza apenas essa língua enquanto língua de instrução e primeira língua, exigindo uma competência cognitiva/escolar do português." (Ibid., p. 9)
\end{abstract}

Neste caso é ainda mais importante o papel desenvolvido pela escola $^{69}$, que além de tudo exercerá também o papel de envolver as mães,

\footnotetext{
${ }^{68}$ Vale destacar ainda a reflexão trazida por Tanya Amara Felipe, que diz:

"A partir dessas capacidades linguísticas, o bilinguismo pode ser analisado como o resultado da aquisição natural ou do processo de aprendizagem formal de duas línguas e, nesse segundo caso, as políticas linguísticas, em um determinado momento, refletem uma visão da sociedade, devido às questões de ordem ideológicas e socioeconômicas que determinam o tipo de educação bilíngue a ser adotada, embora essas políticas possam não levar em consideração o fato dos alunos terem apenas uma competência linguística conversacional e não terem uma competência linguística escolar, que é determinante para o bom desempenho em situações de ensino-aprendizagem da matriz curricular.

$[\ldots]$

Portanto, não se trata apenas de pensar o bilinguismo como o resultado de uma educação bilíngue a partir de questões curriculares, é necessário buscar a melhor alternativa para que um indivíduo ou uma comunidade linguística minoritária tenham seus direitos linguísticos respeitados, uma vez que ser uma pessoa bilíngue tem implicações cognitivas, sociológicas, antropológicas, educacionais, ideológicas e políticas." (Felipe, 2012, p. 8). Para esta autora, para que a educação realmente bilíngue seja alcançada não basta a inclusão curricular das línguas a serem ministradas, mas deve se levar em consideração que a língua minoritária será o principal meio de expressão da comunidade linguística minoritária, no caso dos surdos, será também a única língua conversacional, ou seja, que será utilizada na conversação. Portanto, se faz necessário o ensino efetivo das duas línguas, visto que uma vez inserido em sociedade que diferente língua majoritária o surdo precisa estar inteirado, precisa estar munido meios para ser mais um ator da vida em sociedade e a língua portuguesa, na modalidade escrita, com segunda língua será este instrumento. O que influenciará nos diversos aspectos do "ser" do indivíduo.

${ }^{69}$ Evidente da mesma forma que não olvidamos que o direito social à educação pode ser conquistado no mercado, porém isto não exime o Poder Público da responsabilidade de garantir a educabilidade, fato é que nem todos possuem recursos financeiros suficientes para tal, ademais, muito ocorre da realidade socioeconômica da pessoa surda não lhe permitir dispor de recursos para buscar no mercado a satisfação do seu direito, como bem destaca a Doutora Sueli Fernandes: "A geração de estudantes surdos que constituem o grupo-alvo de nossa ação pedagógica é bastante heterogênea e não corresponde ao ideal bilíngue enunciado nos discursos, pressuposto de uma
} 
pais e/ou responsáveis pelo aluno surdo neste processo de sua estruturação linguística.

É evidente que não se pretende uma educação exclusivamente na língua materna, pois isto seria da mesma forma negativo, condenaria o surdo ao fracasso na vida em sociedade tendo total desconhecimento ou conhecimento insuficiente da língua que o cerca. Como bem coloca Terezinha de Jesus M. Maher, “um 'bom’ bilíngue mistura suas línguas, transita de uma língua para outra, faz uso simultâneo delas justamente porque, diferente do monolíngue, tem competência para tanto" (Maher, 2012, p. 35). Uma política educacional adequada é o que se pretende assegurar, é o meio real de efetivar o direito à educação.

De fato, a Constituição deve conter-se aos limites de razoabilidade para não comprometer seu caráter de instrumento normativo da realidade social, suas normas têm eficácia jurídica e são imperativas, ensejando cumprimento forçado, e devem ser estruturadas de forma a possibilitar a compreensão do que se propõe a norma, e resguardando instrumentos de tutela adequados a tornarem reais e práticas todas as suas proposições (Barroso, 2009, p. 86).

\section{Consoante nos esclarece o Ministro Luís Roberto Barroso:}

"Cuida-se de procurar apreender o verdadeiro alcance das situações jurídicas instituídas pela Constituição, geradoras de pretensões dedutíveis perante o Poder Judiciário, como órgão apto a proporcionar a realização concreta dos comandos normativos, inclusive ante a eventual omissão dos órgãos do Poder Público." (Barroso, 2009, p. 138)

A atuação da esfera judiciária se torna necessária a medida que embora muitos dos direitos sociais existentes da Constituição Federal,

\footnotetext{
prática inclusiva 'bem sucedida'. São crianças, jovens e adultos com histórias atravessadas pelas contradições sociais que os situam em determinada classe social (em sua imensa maioria pertencente às camadas populares da sociedade), com um desenvolvimento marcado por lacunas e descontinuidades nos processos interpessoais na infância, resultando em subjetividades estilhaçadas pelas inconsistentes experiências linguísticas que vivenciam até chegar à escola." (Fernandes, 2012, p. 38). O direito à educação persiste mesmo quando não se possui recursos financeiros, o papel da escola não é receber os alunos apenas, mas garantir efetiva experiência de aprendizado. As escolas tem o grande potencial de gerar marcas na vida das pessoas que influenciarão nos demais aspectos de suas vidas, além da forma como a pessoa se relaciona com o mundo. Essas marcas podem ser boas ou ruins.
} 
muitos "qualificáveis como direitos subjetivos, tutelando bens e interesses pronta e diretamente exigíveis" (Ibid., p. 143) são inteiramente efetivos e geram gozo imediato proporcionando diversos benefícios aos seus destinatários, assim como a possibilidade de sua exigência (Ibid., p. 143), todavia, outros "deixam de concretizar-se, muito embora sejam veiculados em dispositivos que apresentam a mesma estrutura lógico-normativa das demais regras definidoras de direitos, comportando aplicação direta e imediata" (Ibid., p. 143).

É crucial acentuar que para se prestar uma educação de qualidade aos alunos surdos deve-se levar em conta suas especificidades. Não apenas a compreensão e tolerância quanto ao fato de serem minoria linguística e cultural, para efetiva aprendizagem é elementar oferecer a eles as condições necessárias para tal (Coutinho, 2012, p. 61), a qual se compreende que se constrói "dentro de um projeto de educação bilíngue, em que a Libras é a primeira língua, através da qual os surdos constroem suas identidades e subjetividades, e a língua de instrução, enquanto a Língua Portuguesa assume uma perspectiva de segunda língua, com o cuidado de que ambas as línguas sejam igualmente valorizadas ${ }^{70,}$ (Coutinho, 2012, p. 61).

Garantir a efetividade do direito à educação é uma árdua tarefa, no que se trata a educação de surdo, exige ainda outros mecanismos, no entanto a educação é direito de todos e deve ser prestada de forma efetiva. Cabe aqui a célebre defesa de Barroso que elucida:

\footnotetext{
“[...], as dificuldades práticas do deferimento de um pedido condenando o ente público à construção e operação de uma escola podem ser facilmente sanadas por uma providência alternativa ${ }^{71}$ : condenar-se o Estado a custear o estudo do menor em escola privada existente na área. Inviabilizadas todas as alternativas para o cumprimento em espécie da obrigação estatal restará a possibilidade - embora insatisfatória - de obtenção de uma indenização pela omissão ilícita." (Barroso, 2009, p. 144)
}

\footnotetext{
${ }^{70} \mathrm{O}$ que também toca na questão de que é preciso haver profissionais capacitados para desenvolver esta atividade, profissionais também bilíngues e, inclusive, igualmente surdos.

${ }^{71}$ A Lei no 7.853 , de 24 de outubro de 1989, que institui a tutela jurisdicional de interesses coletivos ou difusos de pessoas com deficiência constitui a competência do Ministério Público para atuação na defesa do interesse deste público, bem como disciplina sua atuação.
} 
Não havendo escola pública de ensino básico que garantam o efetivo aprendizado de alunos surdos, caberá a defesa e tutela do interesse da pessoa surda no sentido de compelir o Estado, então, que custeie escola particular que preste a devida educabilidade, que propicie a ele uma verdadeira experiência de aprendizado respeitando e considerando suas necessidades neste processo. $\mathrm{O}$ que não pode ocorrer é que o ensino ministrado com qualidade seja garantia apenas de parte da população. 


\section{CONSIDERAÇÕES FINAIS}

Nossa sociedade ainda não aprendeu a lidar com o diferente em muitos pontos, no entanto, apesar de todos os grupos e lutas existentes, ainda falta aquele que abrace as causas do surdo ou pelo menos que deixe sobressair os já existentes grupos militantes compostos pelos próprios surdos.

Há lutas pela educação e pela educação de qualidade, já é reconhecido que o sistema de ensino brasileiro ainda não é um modelo exemplar e não está perto de ser, porém, apesar de todos os direitos e benefícios já conquistados, pouco se fala das necessidades particulares de aprendizado da pessoa surda, ainda prevalece o olhar de deficiente, que mais precisa da interação (ou exclusão) social, ao invés de minoria linguística e cultural, que tem necessidades educacionais específicas que carecem de guarida.

Não se pretendeu criar uma imagem vitimizada da pessoa surda, muito pelo contrário, sugere um novo olhar a estas pessoas como sujeitos de direitos e aptos a se empoderarem deles. Sujeitos que não precisam de proteção paternalista, mas de reconhecimento e proteção de seus direitos, dignidade, cultura, identidade, contra a discriminação negativa, com participação ativa do Estado, que embora por vezes erre tentando acertar, ainda é reflexo de uma sociedade etnocêntrica.

Equívocos estes que, se tão somente os surdos fossem ouvidos em suas necessidades, não seriam cometidos, se simplesmente a comunidade surda tivesse a oportunidade de expressar o que é melhor para ela, aí sim se estaria dando voz àqueles que hoje são silenciados, não por uma condição genética, mas por uma sociedade que não o leva em conta.

Isto também conforme evidenciado pelas experiências compartilhadas pelas mães com filhos surdos que ofertaram seus 
depoimentos, o que acaba gerando duas sociedades no mesmo espaço geográfico, dois tipos de povo brasileiro. O que é inadmissível.

Deve-se ter em mente que a população surda também é poder constituinte originário e quando esta clama por educação capaz de proporcionar pleno desenvolvimento, clama por uma educação que se adeque a ela, sem a qual seu desenvolvimento não será pleno, mas limitado àquele que ouve, em detrimento de todas as suas capacidades que estão sendo reprimidas.

Também não se pretendeu fazer qualquer espécie de denúncia, mas propor mais atenção às minorias e, principalmente, a minoria de surdos que têm a Libras como primeira língua e não fazem uso da língua oral de forma natural.

Um Estado Democrático de Direito não promove a exclusão social, senão prepara todos os seus cidadãos para o convívio social, propiciando um ambiente de desenvolvimento de suas capacidades fomentando o progresso conjunto segundo os ditames da justiça social e a educação é o ponto de partida para tal, desta forma, a educação de qualidade torna-se essencial neste processo.

Deste modo, a educação de qualidade precisa considerar também aspectos próprios do educando que é parte de uma minoria, o ambiente escolar não pode ser extensão da exclusão social, precisa ser um ambiente de conforto, integração e aprendizado, no qual o aluno, seja ele qual for, aprenderá que tem capacidades, que é valorizado e que ele tem muito a contribuir para a sociedade. É isto que defende o texto constitucional quando dispõe sobre a igualdade, a educação, dignidade humana e a justiça.

Diante disto, é preciso reconsiderar o modelo de educação básica atual, diante de sua ineficácia em promover o direito à educação de todos. É proposto o modelo de educação bilíngue, sendo a Libras primeira língua, língua de instrução, e a Língua Portuguesa segunda língua, exigida na modalidade escrita, e facultada a modalidade oral a ser estimulada pelo profissional competente, isto revelará, além de valorização da língua 
materna e cultura surda, a compreensão do aluno surdo como sujeito de direitos e cujo desenvolvimento também é de responsabilidade do Estado. 


\section{BIBLIOGRAFIA}

AMORIM, Gildete da S. Surdez, Educação e Interpretação em Língua de Sinais. Revista Espaço - Instituto Nacional de Educação de Surdos, Rio de Janeiro, n. 37, jan./jun. 2012. p. 27-34.

BARROSO, Luís Roberto. O Direito Constitucional e a Efetividade de suas Normas: limites e possibilidades da Constituição Brasileira. 9a ed. rev. e atual. Rio de Janeiro: Renovar, 2009. 408 p.

, Luís Roberto. O Controle de Constitucionalidade no Direito

Brasileiro: exposição sistemática da doutrina e análise crítica da jurisprudência. $5^{\mathrm{a}}$ ed. rev. e atual. São Paulo: Saraiva, 2011. 446 p.

BOTO, Carlota. A educação escolar como direito humano de três gerações: identidades e universalismos. In: KOERNER, Andrei [et. al.]; SCHILLING, Flávia (Org.). Direitos Humanos e Educação: outras palavras, outras práticas. São Paulo: Cortez Ed., 2005. p. 87 - 144.

BRASIL, Ministério da Educação. Portaria $n^{o}$. 323, de 08 de abril de 2009.

Diário Oficial [da] República Federativa do Brasil, Brasília, 8 abr. 2009. Seção 1, p. 16, 17.

, Ministério da Saúde. Manual de Legislação em Saúde da Pessoa com Deficiência. $2^{\mathrm{a}}$ ed. rev. e atual. Brasília/DF: Editora do Ministério da Saúde, 2006. 346 p. Disponível em: 〈http://bvsms.saude.gov.br/bvs/publicacoes/legislacao_deficiencia.pdf $>$. Acesso em: 27 abr. 2016.

IBGE. Censo Demográfico, 2010. Disponível em: <http://www.ibge.gov.br/home/presidencia/noticias/imprensa/ppts/0000000 8473104122012315727483985.pdf>. Acesso em: 29 abr. 2016. Convenção Sobre os Direitos das Pessoas com Deficiência (2007). In: BRASIL, Legislação Brasileira sobre Pessoas com Deficiência. Série Legislação, n. 76. $7^{\mathrm{a}}$ ed. Brasília: Câmara dos Deputados, Edições Câmara, 2013. p. 23 - 55. Disponível em: <http://www2.camara.leg.br/documentos- 
e-pesquisa/edicoes/paginas-individuais-dos-livros/legislacao-brasileira-

sobre-pessoas-portadoras-de-deficiencia-1>. Acesso em: 22 abr. 2016.

. Protocolo Facultativo à Convenção sobre os Direitos das Pessoas

com Deficiência (2007). In: BRASIL, Legislação Brasileira sobre Pessoas com Deficiência. Série Legislação, n. 76. $7^{\text {a }}$ ed. Brasília: Câmara dos Deputados, Edições Câmara, 2013. p. 56 - 61. Disponível em: $<$ http://www2.camara.leg.br/documentos-e-pesquisa/edicoes/paginasindividuais-dos-livros/legislacao-brasileira-sobre-pessoas-portadoras-dedeficiencia-1>. Acesso em: 22 abr. 2016.

. Legislação Brasileira sobre Pessoas com Deficiência. Série Legislação, n. 76. $7^{\mathrm{a}}$ ed. Brasília: Câmara dos Deputados, Edições Câmara, 2013. 410 p. Disponível em: <http://www2.camara.leg.br/documentos-epesquisa/edicoes/paginas-individuais-dos-livros/legislacao-brasileira-sobrepessoas-portadoras-de-deficiencia-1>. Acesso em: 18 abr. 2016.

Plano Nacional de Educação (2014). In: Lei no 13.005, de 25 de junho de 2014. Aprova o Plano Nacional de Educação - PNE e dá outras providências. Disponível em: <http://www.planalto.gov.br/ccivil_03/_ato20112014/2014/lei/113005.htm>. Acesso em: 22 abr. 2016.

BRITO, Lucinda Ferreira. Integração Social do Surdo. Trabalhos em Linguística Aplicada. n. 7, 1986, p. 13 - 22. Disponível em: 〈http://revistas.iel.unicamp.br/index.php/tla/article/view/2576/4370>.

Acesso em: 28 abr. 2016.

CANOTILHO, J.J. Gomes. Direito Constitucional; e teoria da Constituição. $7^{\mathrm{a}}$ ed. Coimbra: Livraria Almedina, 2003. 1522 p.

CHOI, Daniel et al.; CUNHA, Maria Cristina da (Org). Libras: conhecimento além dos sinais. São Paulo: Pearson, 2011. 127 p.

COUTINHO, Maria Dolores M. da C. Educação, Matemática e Surdez: um diálogo necessário. Revista Espaço - Instituto Nacional de Educação de Surdos, Rio de Janeiro, n. 37, jan./jun. 2012. p. 60-67. 
DIAS, Francisco. Os direitos humanos, o direito a ser educado e as medidas socioeducativas. In: KOERNER, Andrei [et. al.]; SCHILLING, Flávia (Org.). Direitos Humanos e Educação: outras palavras, outras práticas. São Paulo: Cortez Ed., 2005. p. 237 - 247.

DIDIER Jr., Fredie (Org.). Ações Constitucionais. Salvador: JusPodivm, 2006. 522 p.

DIMOULIS, Dimitri; LUNARDI; Soraya. Curso de Processo Constitucional: controle de constitucionalidade e remédios constitucionais. $2^{\mathrm{a}}$ ed. atual e ampl. São Paulo: Atlas, 2013. 462 p.

DINIZ, Debora; BARBOSA, Lívia; SANTOS, Wederson Rufino dos. Deficiência, Direitos Humanos e Justiça. SUR - Revista Internacional de Direitos Humanos. v. 6, n. 11, dez. 2009, p. 65-77.

FARIA, José Eduardo (Org.). Direitos Humanos, Direitos Sociais e Justiça. $1^{\mathrm{a}}$ ed. $3^{\mathrm{a}}$ tir. São Paulo: Malheiros Editores, janeiro de 2002. 156 p.

FELIPE, Tanya Amara. Bilinguismo e Educação Bilíngue: questões teóricas e práticas pedagógicas. Revista Forum - Instituto Nacional de Educação de Surdos, Rio de Janeiro, n. L 25/26, 26, jan./dez. 2012. p. 0722.

FERNANDES, Sueli. Práticas de Letramento em Contextos de Educação Bilíngue para Surdos. Revista Forum - Instituto Nacional de Educação de Surdos, Rio de Janeiro, n. L 25/26, 26, jan./dez. 2012. p. 37-44.

FERREIRA, Lucinda. Legislação e a Língua Brasileira de Sinais. São Paulo: Ferreira \& Bergoncci Consultoria e Publicações, 2003. 101 p.

FRANCO, Afonso Arinos de Mello. Curso de Direito Constitucional Brasileiro: Teoria Geral. Vol. 1. Rio de Janeiro: Revista Forense, 1958. $230 \mathrm{p}$.

GUANDALIN JR., Walter. A ciência do Direito entre o real e o imaginário: por uma ruptura epistemológica no saber jurídico. In: BAHIA, Alexandre Gustavo Melo Franco ... [et al.] (Org.), FIGUEIREDO, Eduardo Henrique Lopes ... [et al.] (Coord.). Constitucionalismo e democracia. Rio de Janeiro: Elsevier, 2012. p. 25-44. 
KELMAN, Celeste Azulay; BUZAR, Edelice A. Santos. A (In) visibilidade do Aluno Surdo em Classes Inclusivas: discussões e reflexões. Revista Espaço - Instituto Nacional de Educação de Surdos, Rio de Janeiro, n. 37, jan./jun. 2012. p. 04-13.

LABORIT, Emmanuelle. O Grito da Gaivota. Tradução de Angela Sarmento. $2^{\mathrm{a}}$ ed. Lisboa: Editotrial Caminho, 2000. 148 p.

LIMA JR., Jayme Benvenuto. Os Direitos Humanos Econômicos, Sociais e Culturais. Rio de Janeiro: Renovar, 2001. 292 p.

MAHER, Terezinha de Jesus M. Hibridismo e Linguagem: o inevitável diálogo entre Libras e a Língua Portuguesa no discurso do sujeito surdo. Revista Forum - Instituto Nacional de Educação de Surdos, Rio de Janeiro, n. L 25/26, 26, jan./dez. 2012. p. 33-36.

MARTINS, Flavia Bahia. OAB $2^{a}$ Fase: Direito Constitucional. $3^{\mathrm{a}}$ ed. rev., ampl., e atual. Salvador: JusPodivm, 2016. 542 p.

MORAES, Alexandre de. Direitos Humanos Fundamentais: teoria geral, comentários aos arts. $1^{o}$ ao $5^{\circ}$ da Constituição da República Federativa do Brasil, doutrina e jurisprudência. $3^{a}$ ed. São Paulo: Editora Atlas S.A., 2000. 320 p.

MOTTA, Sylvio; BARCHET, Gustavo. Curso de Direito Constitucional. ed. atual. até a $E C n^{\circ}$ 53/06. Rio de Janeiro: Elsevier, 2007. 1096 p.

NOVAES, Edmarcius Carvalho. Surdos: educação, direito e cidadania. $2^{\mathrm{a}}$ ed. Rio de Janeiro: Wak Ed., 2014. 188 p.

NUSSBAUM, Martha C. Educação para o Lucro, Educação para a Liberdade. Revista Redescrições - Revista on line do GT de Pragmatismo e Filosofia Norte-americana. Ano I, número 1, 2009. 27 p. Disponível em: 〈http://www.gtpragmatismo.com.br/redescricoes/principal.htm>. Acesso em: 15 abr. 2016.

ORGANIZAÇÃO DAS NAÇÕES UNIDAS PARA EDUCAÇÃO, CIÊNCIA E CULTURA - UNESCO. 1996. Declaracion Universal de Derechos Linguísticos. Barcelona, 6-9 jun. Disponível em: 
$\langle$ http://www.unesco.org/cpp/sp/declaraciones/linguisticos.htm>. Acesso em: 12 maio 2016.

QUEIROZ, Maria do Socorro Azevedo. Judicialização dos Direitos Sociais Prestacionais: a efetividade pela interdependência dos Direitos Fundamentais na Constituição Brasileira. Curitiba: Juruá, 2011. 194 p.

RAMOS, Barbara E. da C. A Efetividade dos Direitos Sociais. In: XXI Seminário de Iniciação Científica da PUC-Rio, 2013, Rio de Janeiro. Artigo. Rio de Janeiro: PUC-Rio / CNPq, 2013. 20 p. Disponível em: <https://www.puc-

rio.br/ensinopesq/ccpg/pibic/relatorio resumo2013/rel_ces jur.html>.

Acesso em: 10 maio 2016.

RIO DE JANEIRO (Estado), Plano Estadual de Educação (2009). In: Lei n 5597 de 18 de dezembro de 2009. Institui o Plano Estadual de Educação - PEE/RJ, e dá outras providências. Disponível em: 〈http://www.rj.gov.br/web/seeduc/exibeconteudo?article-id=451607〉.

Acesso em: 20 abr. 2016.

RIO DE JANEIRO (Município), Plano Municipal de Educação da Cidade do Rio de Janeiro. In: Lei $\mathrm{n}^{\circ} 4.866$, de 2 de julho de 2008. Anexo. Disponível em: <http://mail.camara.rj.gov.br/APL/Legislativos/contlei.nsf/69d9030724460 2bb032567e800668618/cd432a5690c5b5da032576ac00727775? OpenDocu ment> Acesso em: 20 abr. 2016.

SACKS, Oliver. Vendo Vozes: uma viagem ao mundo dos surdos. Tradução de Laura Teixeira Motta. São Paulo: Companhia das Letras, 2010. 123 p. SILVA, José Afonso da. Curso de Direito Constitucional Positivo. $37^{\mathrm{a}}$ ed. rev. e atual. até a Emenda Constitucional n. 76, de 28.11.2013. São Paulo: Malheiros Editores, janeiro de 2014. 934 p.

SILVA, José Afonso da. Ordenação Constitucional da Cultura. São Paulo: Malheiros Editores, 2001. 250 p.

SILVA, Sidney Pessoa Madruga da. Discriminação positiva: ações afirmativas da realidade brasileira. Brasília: Brasília Jurídica, 2005. 296 p. 
SINGER, Helena. Direitos humanos na escola: a escola democrática. In: KOERNER, Andrei [et. al.]; SCHILLING, Flávia (Org.). Direitos Humanos e Educação: outras palavras, outras práticas. São Paulo: Cortez Ed., 2005. p. $177-185$.

STROBEL, Karin. História da Educação de Surdos. Curso de Graduação em Licenciatura em Letras-LIBRAS na Modalidade a Distância, Universidade Federal de Santa Catarina, Florianópolis, 2009. 49 p. Disponível em: $<$ http://www.libras.ufsc.br/colecaoLetrasLibras/eixoFormacaoEspecifica/hi storiaDaEducacaoDeSurdos/assets/258/TextoBase HistoriaEducacaoSurdo s.pdf>. Acesso em: 28 abr. 2016.

TEIXEIRA, Anísio. Educação Não é Privilégio. $6^{\mathrm{a}}$ ed. Rio de Janeiro: Ed. UFRJ, 1999. $253 \mathrm{p}$.

TV INES. Implante Coclear. Publicado em: 03 de jul. 2014. Duração: 44'11" Disponível em: <http://tvines.com.br/?p=733> Acesso em: 28 abr. 2016. 


\section{Legislação:}

BRASIL, Constituição Federal (1988). Constituição da República Federativa do Brasil. Disponível em: <http://www.planalto.gov.br/ccivil_03/Constituicao/Constituicao.htm>. Acesso em: 21 abr. 2016.

, Decreto $n^{\circ} 3.298$, de 20 de dezembro de 1999. Regulamenta a Lei no 7.853, de 24 de outubro de 1989, dispõe sobre a Política Nacional para a Integração da Pessoa Portadora de Deficiência, consolida as normas de proteção, e dá outras providências. Disponível em: $<$ http://www.planalto.gov.br/ccivil_03/decreto/d3298.htm>. Acesso em: 22 abr. 2016.

Decreto $n^{o} 5.626$, de 22 de dezembro de 2005. Regulamenta a Lei no 10.436, de 24 de abril de 2002, que dispõe sobre a Língua Brasileira de Sinais - Libras, e o art. 18 da Lei no 10.098, de 19 de dezembro de 2000. Disponível em: 〈http://www.planalto.gov.br/ccivil_03/_ato20042006/2005/decreto/d5626.htm>. Acesso em: 22 abr. 2016.

, Decreto $n^{\circ}$ 6.949, de 25 de agosto de 2009. Promulga a Convenção Internacional sobre os Direitos das Pessoas com Deficiência e seu Protocolo Facultativo, assinados em Nova York, em 30 de março de 2007. Disponível em: $<$ http://www.planalto.gov.br/ccivil_03/_ato20072010/2009/decreto/d6949.htm>. Acesso em: 22 abr. 2016. , Decreto $n^{\circ}$ 7.690, de 2 de março de 2012. Aprova a Estrutura Regimental e o Quadro Demonstrativo dos Cargos em Comissão e das Funções Gratificadas do Ministério da Educação. Disponível em: <http://www.planalto.gov.br/ccivil_03/_Ato20112014/2012/Decreto/D7690.htm>. Acesso em: 30 abr. 2016.

Decreto $n^{o}$. 591, de 6 de julho de 1992. Atos Internacionais. Pacto Internacional sobre Direitos Econômicos, Sociais e Culturais. Promulgação. Disponível em: <http://www.planalto.gov.br/ccivil_03/decreto/19901994/d0591.htm>. Acesso em: 05 maio 16. 
, Estatuto da Criança e do Adolescente (1990). Lei no 8.069, de 13 de julho de 1990. Dispõe sobre o Estatuto da Criança e do Adolescente e dá outras providências. Disponível em: <http://www.planalto.gov.br/ccivil 03/LEIS/L8069.htm>. Acesso em: 22 abr. 2016.

, Estatuto da Pessoa com Deficiência (2015). Lei $n^{o}$ 13.146, de 6 de julho de 2015. Institui a Lei Brasileira de Inclusão da Pessoa com Deficiência (Estatuto da Pessoa com Deficiência). Disponível em: <http://www.planalto.gov.br/ccivil_03/_Ato20152018/2015/Lei/L13146.htm>. Acesso em: 22 abr. 2016. , Lei da Libras (2002). Lei $n^{o} 10.436$, de 24 de abril de 2002. Dispõe sobre a Língua Brasileira de Sinais - Libras e dá outras providências. Disponível em: <http://www.planalto.gov.br/ccivil_03/leis/2002/L10436.htm>. Acesso em: 22 abr. 2016.

, Lei de Diretrizes e Bases da Educação (1996). Lei no 9.394, de 20 de dezembro de 1996. Estabelece as diretrizes e bases da educação nacional. Disponível em: <http://www.planalto.gov.br/ccivil_03/leis/L9394.htm>. Acesso em: 22 abr. 2016.

, Lei $n^{o} 13.005$, de 25 de junho de 2014. Aprova o Plano Nacional de Educação - PNE e dá outras providências. Disponível em: $<$ http://www.planalto.gov.br/ccivil_03/_ato20112014/2014/lei/113005.htm>. Acesso em: 22 abr. 2016. , Lei $n^{\circ} 7.853$, de 24 de outubro de 1989. Dispõe sobre o apoio às pessoas portadoras de deficiência, sua integração social, sobre a Coordenadoria Nacional para Integração da Pessoa Portadora de Deficiência - Corde, institui a tutela jurisdicional de interesses coletivos ou difusos dessas pessoas, disciplina a atuação do Ministério Público, define crimes, e dá outras providências. Disponível em: <http://www.planalto.gov.br/ccivil_03/leis/L7853.htm〉. Acesso em: 16 maio 2016. 
Lei $n^{o}$ 7.853, de 24 de outubro de 1989. Dispõe sobre o apoio às pessoas portadoras de deficiência, sua integração social, sobre a Coordenadoria Nacional para Integração da Pessoa Portadora de Deficiência - Corde, institui a tutela jurisdicional de interesses coletivos ou difusos dessas pessoas, disciplina a atuação do Ministério Público, define crimes, e dá outras providências. Disponível em: <http://www.planalto.gov.br/ccivil 03/LEIS/L7853.htm>. Acesso em: 22 abr. 2016.

Pacto Internacional de Direitos Econômicos, Sociais e Culturais PIDESC (1992). In: Decreto $n^{\circ}$. 591, de 6 de julho de 1992. Atos Internacionais. Pacto Internacional sobre Direitos Econômicos, Sociais e Culturais. Promulgação. Disponível em: < $\underline{\text { http://www.planalto.gov.br/ccivil_03/decreto/1990-1994/d0591.htm>. }}$. Acesso em: 05 maio 16. . Supremo Tribunal Federal. Súmulas do Supremo Tribunal Federal. In: SARAIVA, Editora. Vade Mecum Saraiva. Obra coletiva com a colaboração de Luiz Roberto Curia, Livia Céspedes e Fabiana Dias da Rocha. 21 ed. atual. e ampl. São Paulo: Saraiva, 2016. 2304 p.

RIO DE JANEIRO (Estado), Constituição Estadual (1989). Constituição do Estado do Rio de Janeiro. 141 p. Disponível em: <http://www2.senado.leg.br/bdsf/item/id/70450>. Acesso em: 20 abr. 2016. , Lei $n^{\circ} 4.528$, de 28 de março de 2005. Estabelece as diretrizes para a organização do sistema de ensino do estado do Rio de Janeiro. Disponível em: $\quad\langle$ http://www2.alerj.rj.gov.br/lotus_notes/default.asp?link=55\#>. Acesso em: 20 abr. 2016.

RIO DE JANEIRO (Município), Lei Orgânica (1990). Lei Orgânica do Município do Rio de Janeiro. Disponível em: <http://mail.camara.rj.gov.br/APL/Legislativos/organica.nsf/leiorg?OpenFo

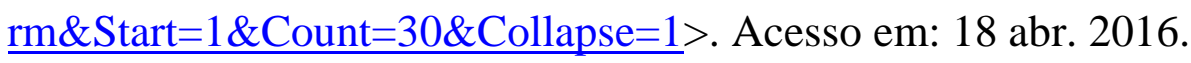
Lei $n^{o}$ 1.756, de 03 de setembro de 1991. Dispõe sobre o atendimento educacional aos alunos portadores de deficiência nas unidades 
da rede municipal de ensino público. Disponível em: <http://mail.camara.rj.gov.br/APL/Legislativos/contlei.nsf/7cb7d306c2b74 $\underline{\text { 8cb0325796000610ad8/a9a4d720c3664a3f032576ac00738b75?OpenDocu }}$ ment> Acesso em: 18 abr. 2016. , Lei $n^{\circ}$ 2.401, de 9 de abril de 1996. Autoriza o Poder Executivo a reconhecer oficialmente no Município, como meio de comunicação objetiva e de uso corrente, a linguagem gestual codificada na Língua Brasileira de Sinais Libras.

Disponível

em:

<http://mail.camara.rj.gov.br/APL/Legislativos/contlei.nsf/2ed241833abd7a 5b8325787100687ecc/0e1a29a2bb0297cd032576ac00733765?OpenDocum ent> Acesso em: 20 abr. 2016.

, Lei $n^{\circ} 4.866$, de 2 de julho de 2008. Aprova o Plano Municipal de Educação e dá outras providências. Disponível em: $<$ http://mail.camara.rj.gov.br/APL/Legislativos/contlei.nsf/69d9030724460 2bb032567e800668618/cd432a5690c5b5da032576ac00727775?OpenDocu ment> Acesso em: 18 abr. 2016.

, Lei $n^{\circ} 5.554$, de 16 de janeiro de 2013. Estabelece diretrizes para a inclusão educacional de alunos com deficiência, transtornos globais de desenvolvimento e altas habilidades/superdotação, e dá outras providências.

Disponível em:

<http://mail.camara.rj.gov.br/APL/Legislativos/contlei.nsf/c5e78996b82f9e $\underline{0303257960005 f d c 93 / b f 8 d c 5 d 334 c 9093 c 03257 a f 6006 c 04 a f ? O p e n D o c u m e}$ nt> Acesso em: 18 abr. 2016. 
Sites:

http://www.ines.gov.br/

http://www.stf.jus.br/

https://ihainforma.wordpress.com/

https://www.facebook.com/feneisrjoficial/timeline 